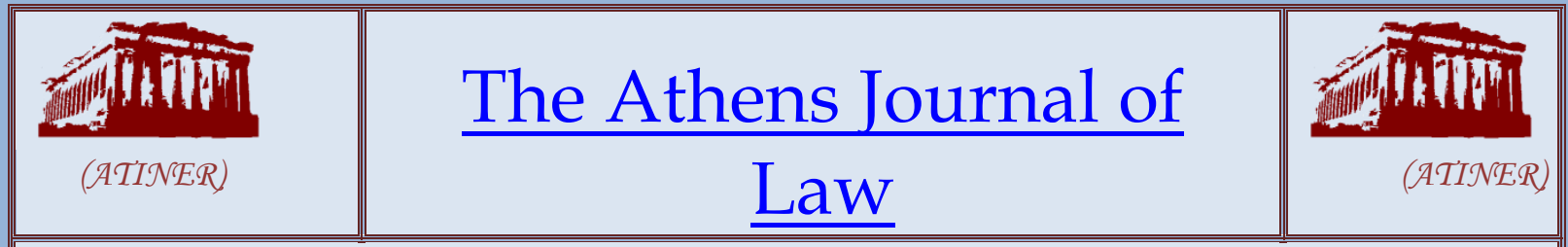 \\ Volume 6, Issue 3, July 2020 Articles
}

Front Pages

PRADEEP KUMAR SINGH

Bail in Socio-Economic Crimes and Criminal Justice in India

PETR ČERNÝ

The Current Trends in the Right of Assembly under the European

Convention on Human Rights

ROBERT SMITH \& MARK PERRY

"Fake News" Legislation in Thailand: The Good, the Bad and the Ugly

ANATOLIY A. LYTVYNENKO

A Right to Access to Medical Records in the Case Law of the Portuguese Courts: Possible Guidelines for future European Court of Human Rights Case Law

CLÉMENT LABI \& WILLY TADJUDJE

The Facelessness of Evil: Towards a Rationale for Corporate Criminal Liability

GEORGE FORJI AMIN

All that Glitters is Not Always Gold or Silver:

Typical Bilateral Investments Treaties (BITs) Clauses as Peril to Third World Economic Sovereignty 


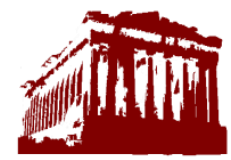

$(A T I \mathcal{N} E R)$

\section{Mission}

ATINER is an Athens-based World Association of Academics and Researchers based in Athens. ATINER is an independent and non-profit Association with a Mission to become a forum where Academics and Researchers from all over the world can meet in Athens, exchange ideas on their research and discuss future developments in their disciplines, as well as engage with professionals from other fields. Athens was chosen because of its long history of academic gatherings, which go back thousands of years to Plato's Academy and Aristotle's Lyceum. Both these historic places are within walking distance from ATINER's downtown offices. Since antiquity, Athens was an open city. In the words of Pericles, Athens"... is open to the world, we never expel a foreigner from learning or seeing". ("Pericles' Funeral Oration", in Thucydides, The History of the Peloponnesian War). It is ATINER's mission to revive the glory of Ancient Athens by inviting the World Academic Community to the city, to learn from each other in an environment of freedom and respect for other people's opinions and beliefs. After all, the free expression of one's opinion formed the basis for the development of democracy, and Athens was its cradle. As it turned out, the Golden Age of Athens was in fact, the Golden Age of the Western Civilization. Education and (Re)searching for the 'truth' are the pillars of any free (democratic) society. This is the reason why Education and Research are the two core words in ATINER's name. 
The Athens Journal of Law

ISSN NUMBER: 2407-9685 - DOI: 10.30958/aj1

Volume 6, Issue 3, July 2020

Download the entire issue $(\underline{\mathrm{PDF}})$

Front Pages $\quad$ i-viii

Bail in Socio-Economic Crimes and Criminal Justice in 209 India

Pradeep Kumar Singh

The Current Trends in the Right of Assembly under the 231

European Convention on Human Rights

Petr Černý

"Fake News" Legislation in Thailand: The Good, the

243

Bad and the Ugly

Robert Smith \& Mark Perry

A Right to Access to Medical Records in the Case Law of

265 the Portuguese Courts: Possible Guidelines for future European Court of Human Rights Case Law

Anatoliy A. Lytoynenko

The Facelessness of Evil: Towards a Rationale for

283

Corporate Criminal Liability

Clément Labi \& Willy Tadjudje

All that Glitters is Not Always Gold or Silver:

Typical Bilateral Investments Treaties (BITs) Clauses as

Peril to Third World Economic Sovereignty

George Forji Amin 


\section{Athens Journal of Law Editorial and Reviewers' Board}

Editors

- Dr. David A. Frenkel, LL.D., Adv., FRSPH(UK), Head, Law Research Unit, ATINER, Emeritus Professor, Law Area, Guilford Glazer Faculty of Business and Management, Ben-Gurion University of the Negev, BeerSheva, Israel.

- Dr. Michael P. Malloy, Director, Business and Law Research Division, ATINER \& Distinguished Professor \& Scholar, University of the Pacific, USA.

\section{Editorial Board}

- Dr. Viviane de Beaufort, Professor, ESSEC Business School, France.

- Dr. Dane Ally, Professor, Department of Law, Tshwane University of Technology, South Africa.

- Dr. Jagdeep Bhandari, Professor, Law department, Florida Coastal School of Law, USA.

- Dr. Mpfari Budeli, Professor, University of South Africa, South Africa.

- Dr. J. Kirkland Grant, Distinguished Visiting Professor of Law, Charleston School of Law, USA.

- Dr. Ronald Griffin, Academic Member, ATINER \& Professor, Washburn University, USA.

- Dr. Guofu Liu, Professor of Migration Law, Beijing Institute of Technology, China.

- Dr. Rafael de Oliveira Costa, Public Prosecutor, Researcher \& Professor, Ministério Público do Estado de São Paulo Institution, Brazil.

- Dr. Damian Ortiz, Prosecutor \& Professor, the John Marshall Law School, USA.

- Dr. Dwarakanath Sripathi, Professor of Law, Osmania University, India.

- Dr. Robert W. McGee, Associate Professor of Accounting, Fayetteville State University, USA.

- Dr. Nataša Tomić-Petrović, Associate Professor at Faculty of Transport and Traffic Engineering, University of Belgrade, Serbia.

- Dr. Emre Bayamlioğlu, Assistant Professor, Koç Universty, Faculty of Law, Turkey.

- Dr. Thomas Philip Corbin Jr., Assistant Professor, Department of Law, Prince Mohammad Bin Fahd University, Saudi Arabia.

- Dr. Mahfuz, Academic Member, ATINER \& Assistant Professor- Head, Department of Law, East West University, Bangladesh.

- Dr. Taslima Yasmin, Assistant Professor, Department of Law, University of Dhaka, UK.

- Dr. Margaret Carran, Senior Lecturer, City University London, UK.

- Dr. Maria Luisa Chiarella, Academic Member, ATINER \& Senior Lecturer, Magna Graecia University of Catanzaro, Italy.

- Dr. Anna Chronopoulou, Academic Member, ATINER \& Senior Lecturer, European College of Law, UK.

- Dr. Antoinette Marais, Senior Lecturer, Tshwane University of Technology, South Africa.

- Dr. Elfriede Sangkuhl, Senior Lecturer, University of Western Sydney, Australia.

- Dr. Demetra Arsalidou, Lecturer, Cardiff University, UK.

- Dr. Nicolette Butler, Lecturer in Law, University of Manchester, UK.

- Dr. Jurgita Malinauskaite, Lecturer in Law, Brunel University London \& Director of Research Degrees, Arts and Social Sciences Department of Politics-History and Law, College of Business, UK.

- Dr. Paulius Miliauskas, Lecturer, Private Law Department, Vilnius University, Lithuania.

- Dr. Jorge Emilio Núñez, Lecturer in Law, Manchester Law School, Manchester Metropolitan University, UK.

- Dr. Ibrahim Sule, Lecturer, University of Birmingham, UK.

- Dr. Isaac Igwe, Researcher, London University, UK.

- Regina M. Paulose, J.D, LLM International Crime and Justice.

- General Managing Editor of all ATINER's Publications: Ms. Afrodete Papanikou

- ICT Managing Editor of all ATINER's Publications: Mr. Kostas Spyropoulos

- Managing Editor of this Journal: Ms. Eirini Lentzou (bio)

\section{Reviewers' Board}

Click Here 


\section{President's Message}

All ATINER's publications including its e-journals are open access without any costs (submission, processing, publishing, open access paid by authors, open access paid by readers etc.) and is independent of presentations at any of the many small events (conferences, symposiums, forums, colloquiums, courses, roundtable discussions) organized by ATINER throughout the year and entail significant costs of participating. The intellectual property rights of the submitting papers remain with the author. Before you submit, please make sure your paper meets the basic academic standards, which includes proper English. Some articles will be selected from the numerous papers that have been presented at the various annual international academic conferences organized by the different divisions and units of the Athens Institute for Education and Research. The plethora of papers presented every year will enable the editorial board of each journal to select the best, and in so doing produce a top-quality academic journal. In addition to papers presented, ATINER will encourage the independent submission of papers to be evaluated for publication.

The current issue is the third of the sixth volume of the Athens Journal of Law (AJL), published by the published by the Business and Law Division of ATINER.

Gregory T. Papanikos President ATINER 


\section{Athens Institute for Education and Research}

A World Association of Academics and Researchers

\section{$1^{\text {th }}$ Annual International Conference on Law \\ 13-16 July 2020, Athens, Greece}

The Law Unit of ATINER, will hold its 17th Annual International Conference on Law, 13-16 July 2020, Athens Greece sponsored by the Athens Journal of Law. The aim of the conference is to bring together academics and researchers from all areas of law and other related disciplines. You may participate as panel organizer, presenter of one paper, chair a session or observer. Please submit a proposal using the form available (https:// www.atiner.gr/2020/FORM-LAW.doc).

\section{Academic Members Responsible for the Conference}

- Dr. David A. Frenkel, LL.D., Head, Law Unit, ATINER \& Emeritus Professor, Law Area, Guilford Glazer Faculty of Business and Management, Ben-Gurion University of the Negev, Beer-Sheva, Israel.

- Dr. Michael P. Malloy, Director, Business, Economics and Law Division, ATINER \& Distinguished Professor \& Scholar, University of the Pacific, USA.

- Abstract Submission: 1 June 2020

\section{Important Dates}

- Acceptance of Abstract: 4 Weeks after Submission

- Submission of Paper: 15 June 2020

\section{Social and Educational Program}

The Social Program Emphasizes the Educational Aspect of the Academic Meetings of Atiner.

- Greek Night Entertainment (This is the official dinner of the conference)

- Athens Sightseeing: Old and New-An Educational Urban Walk

- Social Dinner

- Mycenae Visit

- Exploration of the Aegean Islands

- Delphi Visit

- Ancient Corinth and Cape Sounion

- More information can be found here: https://www.atiner.gr/social-program

\section{Conference Fees}

Conference fees vary from $400 €$ to $2000 €$ Details can be found at: https://www.atiner.gr/2019fees 


\section{Athens Institute for Education and Research}

\section{A World Association of Academics and Researchers}

$8^{\text {th }}$ Annual International Conference on Business, Law \& Economics

3-6 May 2021, Athens, Greece

The Business, Economics and Law Division (BLRD) of ATINER is organizing its $8^{\text {th }}$ Annual International Conference on Business, Law \& Economics, 3-6 May 2021, Athens, Greece, sponsored by the Athens Journal of Business \& Economics and the Athens Journal of Law. In the past, the six units of BLRD have organized more than 50 annual international conferences on accounting, finance, management, marketing, law and economics. This annual international conference offers an opportunity for cross disciplinary presentations on all aspects of business, law and economics. This annual international conference offers an opportunity for cross disciplinary presentations on all aspects of business, law and economics. Please submit an abstract (email only) to: atiner@atiner.gr, using the abstract submission form (https://www.atiner.gr/2021/FORM-BLE.doc)

\section{Important Dates}

- Abstract Submission: $\mathbf{5}$ October 2020

- Acceptance of Abstract: 4 Weeks after Submission

- Submission of Paper: 5April 2021

\section{Academic Member Responsible for the Conference}

- Dr. Gregory T. Papanikos, President, ATINER.

- Dr. Michael P. Malloy, Director, Business, Economics and Law Division, ATINER \& Distinguished Professor \& Scholar, University of the Pacific, USA.

- Dr. David A. Frenkel, LL.D., Head, Law Research Unit, ATINER \& Emeritus Professor, Law Area, Guilford Glazer Faculty of Business and Management, Ben-Gurion University of the Negev, Beer-Sheva, Israel.

\section{Social and Educational Program}

The Social Program Emphasizes the Educational Aspect of the Academic Meetings of Atiner.

- Greek Night Entertainment (This is the official dinner of the conference)

- Athens Sightseeing: Old and New-An Educational Urban Walk

- Social Dinner

- Mycenae Visit

- Exploration of the Aegean Islands

- Delphi Visit

- Ancient Corinth and Cape Sounion

More information can be found here: https://www.atiner.gr/social-program

\section{Conference Fees}

Conference fees vary from $400 €$ to $2000 €$ Details can be found at: https://www.atiner.gr/2019fees 


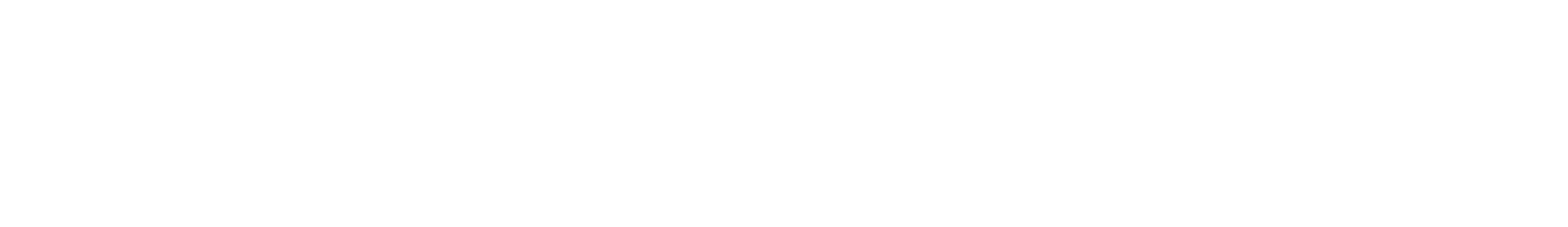




\title{
Bail in Socio-Economic Crimes and Criminal Justice in India
}

\author{
By Pradeep Kumar Singh*
}

\begin{abstract}
Crimes committed by professionals, business men, public servants and organised criminal gangs after well planning by use of modern gadgets in course of performance of their official, professional, business activities in which they have expertise create serious challenge for finance, health and life of members of society and society. In criminal acts committed by professionals, businessmen and public servants, it is very difficult to identify whether sober and civilised activity was committed or criminal act was committed. Economic offenders are only concerned with their personal gain even at the cost of irreparable and serious loss to society which provided socialization and made him a human being, provided status and position, provided respect and reputation, provided stature and means. Money has become marker of power, position, status and reputation and for achieving money persons have no problem even to cause loses to the whole society. In this kind of crime generally evidences are readily not available, and further, fear of abscondance, obstruction in investigation, tampering with evidences appear more probable because of status, position and means of the accused. In such situation need of criminal justice and betterment of society requires special measures to deal with serious problem of socio-economic offences. One such measure is to keep the accused in custody for longer period and for it bail should not be granted in the same manner as granted in case of traditional offences. This paper will deal with and analyse issue relating to grant of bail in case of socio-economic offences.
\end{abstract}

Keywords: Accused; Bail, Criminal justice; Economic offences; Investigation; Money laundering; Organised criminal gangs; Prisonisation; Socialisation; Traditional crime.

\section{Introduction}

Crime is universal and ever-present phenomenon; every society in the world is facing crime challenge, only nature, rate and impact may vary. Crime is most serious challenge to human existence and it is not a new phenomenon but from very inception of society, even before the inception of society, crime, criminals and criminality have been affecting the human life, property and liberty.

Opinions are expressed and reasons are given to prove that crime was in existence and it was causing a serious problem even before origin of society, state and manmade law. It is usually speculated that the society was made, state developed and manmade law was formulated only to deal with crime problem.

*PhD., Professor, Faculty of Law, Banaras Hindu University, Varanasi, Uttar Pradesh, India. E-mail: pradeepsinghk6@gmail.com. 
Before manmade law, crime categories were not defined, acts were not declared as crimes but such problematic acts were causing the same or similar problems even before the origin of society as such acts are causing serious impacts in modern era. ${ }^{1}$

Crime is universal but at the same time one more fact exists for crime that it is relative thereby crime causes problem in each and every society but at the same time nature, rate, impact and ultimately problem caused vary from one society to another society with time and place ultimately with social structure and social process.

With the change in societal structure, social process, scientific and technological know-how crime is becoming day by day graver, complicated, complex and serious problem for the society. Earlier crimes were mostly committed by an individual or few individuals against another individual or few individuals; only due to closely interwoven society and stronger social solidarity, it was considered that crime was committed against the whole society. In reality previously crimes were committed against individual, only by legal fiction it was taken as committed against the whole society. Where persons are closely related and feel emotions of stronger cooperation, an individual may due to need and necessity, enmity and jealousy may commit some acts to affect particular or few persons but he can never think to commit acts to affect and destroy the whole society or considerable part of the society. In previous society a person who sold milk would have mixed some water in it but he could never think to sell synthetic milk. A person who sold rice would have mixed some other grains or husk but he could never think to sell synthetic or unwholesome rice. A person who constructed bridges, school and buildings would have got some undue profit but he could never construct in such manner as to collapse and cause death of many persons. A thief would have stolen some money or articles but never could think to misappropriate public exchequer. In modern era social structure and social process have changed; scientific knowledge and technological know-how are advancing. Further, individual philosophy, feeling of responsibility towards society and fellow citizenry, life style and concept of life, considerations regarding morality and social norms, and ultimately whole social interactions have changed. In such situation individuals have become much concerned with earn more and more money, gain more and more profits and ultimately with his own enjoyment of physical commodities; social solidarity has become much weaker; society and societal members welfare, wellbeing, and protection have become irrelevant considerations.

Change in society has caused complete change in nature, cause, mode, rate and impact of crime on individual member of the society and society at large. Further, all and every stereotype of crime and criminals have completely changed and it is

\footnotetext{
${ }^{1}$ Georgia Florita, Frank Tannenbaum and Emile Durkheim expressed opinions regarding universal nature of crime that crime is ever present phenomenon. Always and in every society crime creates problem. Only kind, nature, seriousness and rate may vary from one society to another. For crime two things which are contrary to each other are true - 1 . Crime is universal; it is found in every society in reference to history and space both. No society is crime free. 2. Crime is relative; nature, seriousness, kind, rate and impact caused for society and societal members vary from one society to another in reference to history and space.
} 
causing greater problem to criminal justice. Previously crimes were committed by un-socialised or mal-socialised or improperly socialised persons for whom all traditional criminologists have been of opinion that they belong to lower class, such criminals were committing crime in unorganised manner without proper planning or completely in un-planned manner by using crude modus operandi leaving clues on crime scene, traditional evidences were available particularly eye witnesses, crimes were committed to satisfy need and necessity or enmity or jealousy or lust. To deal such crimes simple and general measures of criminal justice was efficient. Simple investigating agency and its investigation procedure; traditional prosecution and prosecution measures were effective, traditional sentencing and its infliction was sufficient to tackle problem of traditional criminality.

Crimes are now committed by influential persons belonging to upper class in organised manner after well planning by use of modern gadgets in course of performance of their official, professional, business activities in which they have expertise. Criminal acts committed by professionals, businessmen and public servants, it is very difficult to identify whether sober and civilised activity was committed or criminal act was committed. Such criminals have no criminal selfimage, further by societal members there is no labelling which affect seriously pursuits to cope with crime and criminality. ${ }^{2}$ Economic offenders are only concerned with their personal gain even at the cost of irreparable and serious loss to society which provided socialization and made him a human being, provided status and position, provided respect and reputation, provided stature and means. In State of Gujarat v. Mohanlal Jitamalji Porwal ${ }^{3}$ the Supreme Court observed:

\footnotetext{
${ }^{2}$ For dealing with crime and criminality some very important requisites are creation of deviant categories, violator of deviant category and his violation of deviant category, institutional and noninstitutional definition of act as violation of deviant category and such violator as deviant, ultimately violator himself should accept such image and prepared to accept reactions against his violations of deviant categories. When society through its institutional and non-institutional measures accepts act as criminal, then it may use criminal justice system and further, society may react against crime and criminal. When doer of act has self-image as criminal, he himself will identify that he has committed act against values of society, he will ready to receive punishments and make all his attempts to reform himself. In case of modern criminality society usually considers that the professional is expert in his profession and performing his acts efficiently to earn more and get success. Acts committed are usually as professional act, even if taken as wrong only as civil wrong, generally not defined as criminal act. In some circumstances, if, institutions have defined deviant category and deviant, non-institutional definitions are lacking. Criminals of modern criminality does not satisfy stereotypes of criminal as he is well educated, rich person, successful in his professional life, well placed etc. Therefore, society does not consider him as criminal and his acts as criminal acts and usually does not react against modern criminality. Social reputation of such deviant person is not affected as it happens in case of criminal of traditional criminality. is also not affected Criminal of modern criminality never considers that he is criminal, he has no criminal self-image. Always he considers that he is performing his professional acts with more expertise, therefore he is not prepared for receiving reactions of society and he does not prepare to reform his criminal acts causing problem to society and members of society. In tackling crime social reaction, social control and social reputation play crucial roles.
}

${ }^{3}(1987) 2$ SCC 364. 
"[...] the entire community is aggrieved if the economic offenders who ruin the economy of the State are not brought to book. A murder may be committed in the heat of moment upon passions being aroused. An economic offence is committed with cool calculation and deliberate design with an eye on personal profit regardless of the consequence to the community. A disregard for the interest of the community can be manifested only at the cost of forfeiting the trust and faith of the community in the system to administer justice in an even-handed manner without fear of criticism from the quarters which view white collar crimes with a permissive eye unmindful of the damage done to the national economy and national; interest $[\ldots]$ "'

To gain more and more profit, to become rich quick such criminal even has no problem to cause problem for the whole society, affect safety and security of life of societal members, misappropriation of public exchequer and ultimately affect completely wellbeing of society at large. In the way to accumulate money and to get physical commodities, life, property and well-being of common persons have no value. Criminal acts committed by such persons are creating a serious challenge before criminal justice system; It is difficult to identify whether crime was committed, when it is identified that crime was committed, it is difficult to find out clues and thereby evidences; when evidences are available, nature of evidences is completely different as not possible to be collected by simple investigating, presented by prosecution agency and ultimately to convict and sentence; when sentenced, simple sentence is not effective to deal with such modern criminals and their criminality. A criminal of such modern criminality are respected and influential persons with position, status, standing and means thereby they are always in situation to influence proceeding in investigation and prosecution, tamper with the evidences and pressurise witnesses. Against such influential criminals, societal reactions is usually absent, it further complicate and affect the criminal justice measures to effectively deal with modern criminality.

To differentiate from traditional crimes, to formulate effective policies, to enact effective law, to enforce law by effective enforcement agencies, crimes committed by influential persons given a distinct name 'socio-economic crimes'. Socio-economic crimes cannot be effectively dealt by the same measures applicable for traditional crimes.

\section{Considerations for Granting Bail are not same for Traditional Crimes and Socio-economic Crimes}

During investigation an accused is arrested to ensure his cooperation with investigating agency, availability for effective investigation particularly custodial investigation, safety and security of witnesses and other evidences, availability before the court for participation in trial and infliction of punishment in case of conviction. During investigation a person is arrested and kept in custody with aforesaid objectives and not at as infliction of any punishment therefore when such person gives assurance and further competent authority is satisfied that person is fit and even if he will be released, his behaviour will be proper. When it is shown before the competent authority that the released person will act as per requirement 
of criminal justice, there is no need of keeping person as under-trial prisoner, person is immediately granted bail and released. Even before custody of the person he may be directed to be released which is called as Anticipatory bail. In case of traditional crimes evidences are readily available, generally the accused is not an influential person and thereby unable to influence investigation, the accused is not in situation to tamper with and terrorise evidences and witnesses, generally the accused is not in situation to abscond to some other country, therefore in traditional crimes for bail it is well established rule that generally bail should be granted and exceptionally bail may be refused. ${ }^{4}$ At this stage it has not been decided that he has committed crime, he may be innocent person.

Deprivation of liberty of such person may not be appropriate. Further, prison atmosphere causes prisonisation ${ }^{5}$ of person kept in prison; he may be initially innocent and not a criminal but when he comes out after longer incarceration as under-trial prisoner now he may have become hardened criminal. Criminal justice makes presumption that the accused person is innocent till his guilt is proved beyond reasonable doubts, in such situation it will be contrary to keep person behind bar only on the basis of accusation. When a person is kept as under-trial prisoner, he may loss his earnings, he may not hire services of advocate for his protection, he may not be able to collect evidences for his defence; such situations badly affect basic premise of fair trial. When after trial it is proved that the accused was innocent, who will be answerable for his longer period of deprivation of personal liberty. Furthermore, the accused may have committed crime or not, it may be decided after conclusion of trial but if person is kept in prison as undertrial prisoner, it may amount to infliction of punishment on his dependent family members.

Criminal justice has well established premise that after ensuring the accused person's proper behaviour normally bail should be granted; refusal of bail should be only in exceptional situation when it appears that the accused may show improper behaviour and may cause problems for criminal justice dispensing. The law relating to bail has certain premise and underlying philosophy which is crucial for justice administration thereby criminal justice dispensing. For considering bail two things are always balanced - one, requirement of criminal justice which is manifested as social interest, sometimes it is also reflected as police power to restrict liberty of a man who is alleged to have committed crime, and second,

\footnotetext{
${ }^{4}$ Our legal system is based on concept of fair trial accordingly an accused is treated as innocent till his guilt is proved beyond reasonable doubts, before it such person is treated as an accused person and may be detained in custody only for satisfaction of requirements of criminal justice. The fundamental and established rule is that when person is not a substantial risk for requirements of criminal justice as it usual in traditional crimes (like there is no fear to witnesses and evidences, person co-operates in investigation and trial, available or conviction and punishment), generally bail should be granted. See cases - State of Rajasthan v. Balchand AIR 1977 SC 2447, Gudikanti Narasimhulu v. Public prosecutor AIR 1978 SC 429, Babu Singh v. State of Uttar Pradesh AIR 1978 SC 527, Hussainara Khatoon v. State of Bihar AIR 1979 SC 1360.

${ }^{5}$ Prisonisation term is used for learning of prison behaviour; it is similar to socialization. As by socialization norms and values of society are learnt, similarly prison inmate learns prison behaviour. In prison criminogenic forces are more thereby a person kept in prison is prone to drift towards criminality or when he has primary deviance, he is prone to drift towards secondary deviance and ultimately his criminality matures in recidivism.
} 
presumption of innocence in favour of alleged accused which is usually shown as individual interest. But same rule of bail cannot be applied in socio-economic crimes. Socio-economic crimes are completely different criminality in every reference therefore same rule for granting bail cannot be applied. In socioeconomic crimes bail cannot be granted in the same way as it is granted in traditional criminal cases.

Economic offences are committed for personal profit and it affects well-being of whole society particularly cause huge loss to public fund. In Mrs Leena Mahesh v. Republic of India ${ }^{6}$ was relating to chit fund relating offences in Orissa. Coaccused got bail in the case. Now bail petition was filed by an accused who together with her husband established many companies which were involved in chit fund and by that means misappropriations. The Court refused give bail even though co-accused persons were already on bail. The Orissa High Court observed:

"Therefore, economic offences are considered grave offences as it affects the economy of country as a whole and such offences having deep rooted conspiracy and involving huge loss of public fund are to be viewed seriously. Economic offences are committed with cool calculation and deliberate design solely with eye on personal profit regardless of the consequence to the community. In such type of offences, while granting bail, the Court has to keep in mind, inter alia, the larger interest of public and state. The nature and seriousness of an economic offence and its impact on society are always important considerations in such a case and those aspects must squarely be dealt with by the Court while passing an order on bail application."

\title{
In the case of State of Bihar v. Amit Kumar ${ }^{7}$ the Supreme Court observed:
}

\begin{abstract}
"We are also conscious that if any undeserving candidate allowed to top exams by corrupt means, not only will the society be deprived of deserving candidates, but it will be unfair for those students who have honestly worked hard for one whole year and are ultimately disentitled to a good rank by fraudulent practices prevalent in those examinations. It is well settled that socio-economic offences constitute a class apart and need to be visited with a different approach in the matter of bail. Usually socioeconomic offence has deep rooted conspiracies affecting the moral fiber of the society and causing irreparable harm, needs to be considered seriously." ${ }^{8}$
\end{abstract}

State of Bihar v. Amit Kumar case was relating to Bihar Topper Scam. In 2016 Bihar Intermediate School Board Examination from one school many students got place in 10 toppers list. Electronic media interviewed such toppers which revealed that they did not have sufficient knowledge to top the Board Examination; even they could not pass the examination. FIR was lodged and police started investigation. Investigation revealed fraudulent practices prevailing in Bihar Intermediate Examination involving students and management of the Vishnu Rai College. Respondent in this case was Principal of the College. When raid was made in premises belonging to an accused unaccounted larger amount of

\footnotetext{
${ }^{6}$ http://Indiankanoon.org/oc/59681/

${ }^{7}$ AIR 2017 SC 2487.

${ }^{8}$ Ibid at 2491.
} 
cash and property was recovered. In addition to it, large number of answer sheets, letter-heads and rubber stamps of several authorities, admit cards, illegal fire arms etc. were found. Bail petition was moved and bail was granted by the High Court. State challenged bail order before the Supreme Court which set aside the order of the High Court. The Supreme Court observed that no doubt 'bail is rule and jail is an exception' is well established rule of our criminal; jurisprudence but there is no straight-jacket formula for consideration of grant of bail to an accused. Granting of bail depends on fact and circumstances of each case. Socio-economic offences need application of different approach in the matter of bail and should be considered seriously.

\section{Status, Position, Standing and Means of the Accused}

Offender of socio-economic offence is influential person with status, position, standing and means thereby always probability exits that he may influence investigation and prosecution variously. He is in position to pressurise witness from giving statements and temper with evidences. Socio-economic crimes have serious impact over society at large and for societal interests require that such crime must be tackled at any cost. Therefore ones offender of socio-economic offence is arrested, for the sake of protection of society and effective dispensing of criminal justice he should not be granted bail and he should remain in jail till completion of investigation and prosecution.

In State of UP v. Amarmani Tripathi ${ }^{9}$ the Supreme Court directed for consideration of certain circumstances for disposal of bail application

1. Whether there is any prima facie or reasonable ground to believe that the accused has committed the offence;

2. Nature and gravity of the charges;

3. Severity of the punishment in event of conviction;

4. Danger of the accused absconding or fleeing, if released on bail;

5. Character, behaviour, means, position and standing of the accused; likelihood of offence being repeated;

6. Reasonable apprehension of the offence being repeated;

7. Reasonable apprehension of the witnesses being tampered with; and

8. Danger, of course, of justice being thwarted by grant of bail.

Amarmani Tripathi was political leader and he was MLA therefore he was in position to influence investigation variously, the Court refused to grant bail and emphasised for consideration means standing and position of the accused means how much the accused is influential should be considered in granting bail. Amarmani Tripathi case was relating to murder which is traditional crime but case is relevant for socio-economic offences also as the accused was influential person, (he was political leader) as it happens in case of socio-economic offences. The Court's directions given in this case is relevant for socio-economic offences also.

${ }^{9}(2005) 8$ SCC 21. 
In Anil Kumar Tulsiyani v. State of $U P^{10}$ bail granted by the High Court was cancelled on the ground that the accused had position and standing as advocate in the High Court which may be misused.

An accused in India is considered as innocent but there are certain requirements of criminal justice for the sake of which restrains on liberty of person may be imposed. Personal Liberty of an individual is most crucial and important fundamental right granted in Article 21 of Constitution. Article 21 itself permits deprivation of personal liberty by procedure established by law. Socio-economic crimes create serious challenge for society at large therefore for protection of society a person may be deprived of his personal liberty. Society is always considered more important than individual. For societal protection some individual right even very important fundamental right may be curtailed. In case of Rajesh Ranjan Yadav @ Pappu Yadav v. CBI through Its Director ${ }^{11}$ the Supreme Court observed that Article 21 is of great importance because it enshrines the fundamental right to individual liberty but at the same time a balance has to be struck between the right to individual liberty and the interest of society. While it is true that one of the considerations in deciding whether to grant to an accused or not is whether he has been in jail for a long time, the Court has also to take into consideration other facts and circumstances such as the interest of the society. In granting of bail individual interests are always considered but more important consideration to be given utmost emphasis is interest of society and in particular interest of criminal justice.

In socio-economic crime offender has such influential position which may be utilised and affect the investigation and trial. Generally evidences are not available in socio-economic crime cases, if, available may be prone to be affected by criminal put not behind the bar. Therefore societal interest requires that whenever such offender is identified, should be put in custody and bail should not be granted to him as generally provided in case of traditional crimes. It is well established principle of law that the accused is unfit for bail when there is probability of pressurizing of investigating officer, putting obstruction in investigation, causing fear of tampering of evidences and terrorizing witnesses. In case of socioeconomic offender due to his status, position, and standing of the accused probability in aforesaid regards are always evident. Because of that the accused of socio-economic crime is considered as unfit for bail. In Neeru Yadav v. State of Uttar Pradesh ${ }^{12}$ the Court observed:

"We will be failing in our duty if we do not take note of the concept of liberty and its curtailment by law. It is an established fact that a crime though committed against an individual, in all cases it does not retain an individual character. It, on occasions and in certain offences, accentuates and causes harm to the society. The victim may be an individual, but in the ultimate eventuate, it is the society which is the victim [...] in a civilised society, and a crime disturbs orderliness. [...] It affects the peaceful life of the society. An individual can enjoy his liberty which is definitely of paramount

\footnotetext{
${ }^{10} 2006$ (5) SCALE 233.

${ }^{11}$ AIR 2007 SC 451.

${ }^{12}$ AIR 2015 SC 3703.
} 
value but he cannot be a law unto himself. He cannot cause harm to others. He cannot be nuisance to the collective. He cannot be terror to the society;" 13

Socio-economic criminals are economically sound and belong to elite class. Furthermore, they commit crime to get more and more money. They are in possession of large amount of proceed of crime. When a person has money earned by honesty and labour, they think again in in spending the money but when money is obtained by corrupt means, such person may not have any problem spending. A criminal of economic offences has larger amount of proceed of crime, he may use it and affect the investigation and win over witnesses. In Himanshu Chandravadan Desai v. State of Gujrat ${ }^{14}$ the appellant -accused was one of directors of a Bank and together with other directors and managing director of Bank siphoned off crores and crores rupees fund of the Bank by bogus loans and fictitious letters of credit in the name of their friends, relatives, associates and name-lender companies either without any securities or with wholly inadequate security. The Court of Session and the High Court rejected bail and then the appellant-accused moved the Supreme Court. The accused was remaining in custody for longer period since his surrender on 24.10.2002. The Supreme Court decided that having regard to huge amounts involved in the systematic fraud, there is danger of the appellants absconding, if released on bail, or attempting to tamper with the evidences by pressurizing witnesses. The Supreme Court refused to grant bail. In socioeconomic offences always the court considers monetary position of the accused and amount involved in criminal case. More the accused is economically sound and more the amount involved in criminal case; it cause more the chance of affecting the requirements of criminal justice, more the accused is unfit for bail, thereby, more the chance of refusal to grant bail.

In Sudhir V. State of Maharashtra ${ }^{15}$ the accused were engineers in Rural Water Supply Department of Zilla Parishad, Jalagaon. They were executing work of supply of drinking water to some villages in Jalgaon Maharashtra. They committed corruption and misappropriated the fund. On paper toilets and barbed fencing were constructed. Amount was released in the name of a contractor, who was non-existent. Hereby whole fund was misappropriated. On the direction commissioner matter was enquired by Dy. Commissioner and he found substance in allegation. FIR was lodged under IPC and Prevention of Corruption Act. Anticipatory bail was granted to the accused by Additional Session Judge. State filed appeal before the High Court which set aside order of anticipatory bail. Now the accused filed appeal before the Supreme Court against the order of the High Court. The Supreme Court differentiated this case from other cases that in this case there were serious allegations of corruptions and misappropriation of funds. This case cannot be equated with simple cases in which anticipatory bail is granted. In Gurubux Singh Sibia v. State of Punjab Case (AIR 1980 SC 1632) The Court expressed opinion that even in case of economic offences and corruption cases when allegations are mala fide, anticipatory bail may be granted. But in this case

\footnotetext{
${ }^{13} \mathrm{Ibid}$ at 3707.

${ }^{14}$ AIR 2006 SC 170.

${ }^{15}$ AIR 2015 SC 3665.
} 
there was no mala fide as Commissioner and Dy. Commissioner acted on fact; enquiry was made and on the basis of fact disclosed, FIR was lodged. In corruption cases with serious conspiracies the Supreme Court expressed its disapproval for grant of anticipatory bail. The Supreme Court considering gravity of offence of misappropriation of funds released for rural development opined that the custodial investigation is necessary; if, anticipatory bail direction is passed, it will be affected. Therefore the Court dismissed appeal and upheld order passed by the High Court.

A Person accused of socio-economic crime is richer further in possession of larger proceed of crime; therefore he may not have any hesitation in spending it for influencing the course of criminal justice. In such case even he has been found as fit for bail, it would be appropriate to take larger security for release on bail. Normally in case of traditional offences when the accused is fit for bail normally lesser security is taken for release on bail as in section 440 (1) CrPC direction is given that amount of bond shall not be excessive. ${ }^{16}$ But lesser security amount for release on bail in socio-economic offences is not considered sufficient to compel for proper behaviour during released situation. In Bharat Stars Services Pvt. Ltd. V. Harsh Dev Thakur ${ }^{17}$ the Supreme Court decided that Rs. 50 Lakhs security amount was not sufficient and ordered to give further amount of Rs. 75 Lakhs. This case was involving embezzlement to the tune of Rs. 2.78 Crores. The accused respondent along with his family members committed offence of embezzlement. All co-accused absconded and were not available. The Court framed charge against the accused by segregating the co-accused. The accused was in custody since $10^{\text {th }}$ November 2017 thereby remaining custody for longer period. Investigation was complete, available properties of the accused and co-accused was attached and further, documents relating to case were attached. Case was mainly depending on documents. Hereby, there was no fear to affect the case. The High Court granted bail and directed to deposit Rs. 50 Lakhs. The Supreme Court considered that it was case of embezzlement of more than 2.75 Crores and in such a case more stringent conditions should be imposed. The Supreme Court directed for additional security of Rs. 75 Lakhs thereby security of Rs. 1.25 Crores (Rs. 50 Lakhs + Rs. 75 Lakhs) was taken. Further conditions were imposed to deposit passport with trial court and present once in every week before jurisdictional police station.

\section{Accused are Prone to Flee from Justice Particularly to abscond to some Foreign Land}

Accused persons of economic offences are richer persons and further, larger proceed of crime is involved, therefore there is greater probability of the accused to abscond to some other country and thereby flee from course of justice. Recently in many cases such incidents are happening. In case of accused of socio-economic

\footnotetext{
${ }^{16}$ Section 440 (1) CrPC provides: The amount of every bond executed under this Chapter shall be fixed with due regard to the circumstances of the case and shall not be excessive."

${ }^{17}$ AIR 2019 SC 718.
} 
offences to secure availability of the accused for effective enforcement of criminal justice, it is needed that immediately the accused be brought under custody. Main measure for taking into custody is arrest of the person but for that availability of sufficient evidences giving reason to belief of involvement of the accused in crime commission is required. In socio-economic offences it is very difficult to identify whether offence was committed; even when it is identified, it is very difficult to get clues; and even hen clues are available, it is difficult to identify and collect evidences. Therefore, in very initial stage of socio-economic crime law enforcement agencies are not in situation to arrest the offender. Furthermore, the accused has status, position and respect in the society which makes his arrest more difficult. To enable effective investigation for socio-economic offences preventive detention Acts are enacted permitting preventive detentions. The accused before his arrest and detention flee to some other country; or attempt to get anticipatory bail or after coming in custody get bail; and attempt to flee to some other country. In Amarmani Tripathi case Court emphasised on this aspect that the court should consider danger of the accused absconding and fleeing, if released on bail. In Bhadresh Bipinbhai Sheth v. State of Gujarat ${ }^{18}$ The Supreme Court expressed opinion about exercise of power to grant anticipatory bail and observed that the discretion vested with the court under section 438 Criminal Procedure Code (CrPC) should be exercised with caution and prudence. Grant or refusal of anticipatory bail should necessarily depend on the fact and circumstances of each case. In this regard the Court directed to consider impact of grant of anticipatory bail particularly in cases of large magnitude affecting a very large number of people, reasonable apprehension of tampering of the witness, possibility of applicant to repeat crime, and possibility to flee from justice.

The Supreme Court decided P. Chidambaram v. Directorate of Enforcement ${ }^{19}$ case on 5 September 2019 and observed that economic offences stand as a different class as they affect the economic fabric of the society. Power under Section $438 \mathrm{CrPC}$ being an extraordinary remedy, has to be exercised sparingly; more so, in cases of economic offences. In this case allegation was against the former Union Finance Minister and his son for corruption, money laundering and giving illegal benefit to a media house. There were alleged irregularities in Foreign Investment Promotion Board (FIPB) clearance given to the INX media for receiving foreign investment to the tune of Rs. 305 crores against approved inflow of Rs. 4.62 Crores. CBI and ED lodged FIR. Appellant filed petition before the Delhi High Court requesting for grant of anticipatory bail. The High Court refused to grant anticipatory bail in both the cases. Appellant filed appeal before the Supreme Court but before hearing he was arrested by CBI for case under investigation before it thereby appeal petition relating to case under investigation by CBI became in-fructuous in light of Gurubaksh Singh Sibbia v. State of Punjab (AIR 1980 SC 1632) judgment as anticipatory bail is available only before arrest. In appeal grant of anticipatory bail was considered for case under investigation by ED. The Court refused to give anticipatory bail to the appellant on the ground that in complicated cases investigating agency should have freedom to investigate the

\footnotetext{
${ }^{18}$ AIR 2015 SC 3099.

${ }^{19}$ https://indiankanoon.org/doc/90251163/2/24/2020
} 
case. The Court opined that anticipatory bail may hamper investigation. Grant of anticipatory bail at the stage of investigation may frustrate the investigating agency in interrogating the accused and in collecting the useful information and also materials which might have been concealed. Ordinarily, arrest is part of the process of the investigation intended to secure several purposes particularly for custodial investigation. Grant of anticipatory bail, particularly in economic offences would definitely hamper the effective investigation. The Supreme Court observed that in money laundering cases anticipatory bail may affect the effective investigation:

"In case of money-laundering where it involves many stages of "placement", "layering i.e. funds moved to other institutions to conceal origin" and "interrogation i.e. funds used to acquire various assets", it requires systematic and analysed investigation which would be of great advantage. As held in Anil Sharma, success in such interrogation would elude if the accused knows that he is protected by a prearrest bail order. Section $438 \mathrm{CrPC}$ is to be invoked only in exceptional cases where the case alleged is frivolous or groundless. In the case in hand, there are allegations of laundering the proceeds of the crime... Having regard to the nature of allegations and the stage of the investigation, in our view, the investigating agency has to be given sufficient freedom in the process of investigation[...]"

While P. Chidambaram was in custody he moved regular bail petition but it was dismissed by the High Court. Before the High Court on three grounds 'Flight risk', tampering with evidences and influencing witnesses - CBI requested for refusal to grant bail. The High Court considered and found that there was no flight risk as some measures are available like surrender of passport, issuance of look-out notice and such other directions may be used. The High Court observed that there was no fear of tampering of evidences as in this case documents are in custody of the prosecuting agency, Government of India and the Court. But the High Court accepted third ground, influencing the witnesses, that the investigation was in an advance stage and the possibility of the appellant influencing the witnesses cannot be ruled out. High Court refused to grant bail.

Against the decision of the High Court the appellant filed appeal petition before the Supreme Court and it was entertained as case P. Chidambaram v. Central Bureau of Investigation ${ }^{20}$. The Supreme Court accepted the view of the High Court that flight risk may be secured by issuing certain directions like surrender of passport and issuance of look-out notice. The Supreme Court also accepted that in this case all documents are with prosecution, government and court therefore there is no fear of tampering with evidences. The Supreme Court did not accept view of the High Court regarding influencing of witnesses. The Supreme Court set aside order of the High Court and directed for grant of regular bail. The Supreme Court observed that the appellant is not a 'flight risk'. The appellant is in custody for about two months. The co-accused was already granted bail. The appellant was 74years and was suffering from age related health problems. On many occasions remand was granted but never it was informed that

\footnotetext{
${ }^{20} \mathrm{https}: / /$ indiankanoon.org/oc/182852774/2/24/2020
} 
appellant was influencing witnesses. Charge-sheet has already been filed. On these grounds bail was granted. The Court expressed opinion that flight risk should be considered in economic offences but only on this basis fitness for bail cannot be decided; every case should be considered on its own fact and circumstances. The Court in this case did not accept that there was flight risk and opined that some measures, like - surrender of passport and look-out notice, were sufficient to deal with flight risk. The Court observed:

\begin{abstract}
"There is no hard and fast rule regarding grant or refusal to grant of bail. Each case has to be considered on the facts and circumstances of each case and on its own merits. The discretion of the court has to be exercised judiciously and not in arbitrary manner. At this stage itself, it is necessary for us to indicate that we are unable to accept the contention of the learned Solicitor General that "flight risk" of economic offenders should be looked at as a national phenomenon and be dealt with in that manner merely because certain other offenders have flown out of the country. The same cannot, in our view, be put in a straight-jacket formula so as to deny bail to the one who is before the Court, due to the conduct of other offenders, if the person under consideration is otherwise entitled to bail on the merit of his own case. Hence, in our view, such consideration including as to "flight risk" is to be made on individual basis being uninfluenced by the unconnected cases, more so, when the personal liberty is involved."
\end{abstract}

In socio-economic offences proceed of crimes are larger and further, offenders are economically sound, therefore, in releasing them on bail probability of abscondance not within country but beyond country is more probable. Usually socio-economic offenders abscond to some other country and after that it becomes difficult to bring them back and complete the criminal proceeding against them. In such situation it would be better when economic offender is arrested, bail should be granted only after due consideration of his 'flight risk'. Further, his monetary sound condition particularly proceed of crime obtained not by his honest working but by deceiving others causes more prone situation for influencing witnesses and other evidences. Furthermore, status and position of offender provides opportunity to influence investigation and prosecution. In such situations an accused kept in custody should not be granted bail particularly before completion of investigation.

\title{
Case is Prima Facie Established
}

It is well established premise in law relating to bail that when case is prima facie established, generally bail is not granted. When case is prima facie established, the accused also gets impression that after trial he may be convicted and sentenced, therefore, the accused becomes prone for interfering with course of criminal justice system like he may attempt to abscond, influence investigation, tamper with evidences and terrorise witnesses.

Such circumstances itself suggest that the accused is not fit for bail. Provisions in Criminal Procedure Code (CrPC) and other Penal Acts direct the Courts for considering prima facie situation of case. Further, the Supreme Court 
has given directions to calculate prima facie satisfaction regarding crime commission. At this stage evidences are not considered on merit but availability and nature of evidences are only considered. Section 437 (1) (i) $\mathrm{CrPC}$ prescribes that when offence is punishable by death penalty or life imprisonment and case is prima facie established, the accused is not released on bail. Section 437 (2) CrPC provides that when case is not prima facie established and for further proceeding need of further inquiry is felt; bail shall be granted. Fourth proviso to Sec 437 (1) CrPC suggest the same thing by providing that in case of serious offences, the Court can take decision about bail only after hearing the public Prosecutor. Hearing public prosecutor indicates for need of considering prima facie situation of the case. These provisions contained in Section 437 CrPC directs that when matter of bail is under consideration releasing authority should consider prima facie situation of case and when case is prima facie established, bail has to be denied and when case is not prima facie established, bail may be granted. Same considerations are applicable for grant of bail by superior courts $\mathrm{u} / \mathrm{s} 439 \mathrm{CrPC}$, although not given explicitly in the provisions contained in the section $439 \mathrm{CrPC}$. In Ram Govind Upadhyay v. Sudarshan Singh ${ }^{21}$ the Supreme Court observed that grant of bail is discretionary power exercise but requires exercise of power in judicious manner and not as matter of course. The Court directed to consider various things including prima facie satisfaction of the court in support of charge. For this purpose there is no need to consider the entire evidences establishing guilt of accused beyond reasonable doubt; only prima facie satisfaction is sufficient.

Whenever case is prima facie established, the accused fear that ultimately with disposal of case he may be convicted and punished therefore always he is considered prone for acting against requirement of criminal justice. In such situation it would not be prudent to release person from custody. In socioeconomic crimes generally clues and evidences are not available to law enforcement agencies particularly evidences proving mens rea are not available as it may be in traditional crimes. Further, an accused is influential person and thereby in situation to affect the evidences and course of criminal justice. Furthermore, this sort of crime is committed because of greed, avarice and rapaciousness; the accused never satisfies with money and want to have more and more money therefore as and when opportunity becomes available accused is prone to commit crime again. At the same time socio-economic crimes are serious challenge for wellbeing of whole society, any compromise cannot be made.

Normally for traditional offences presumption is for innocence of the accused and further burden of proof lies on prosecution. In Special Penal Acts dealing with socio-economic offences presumption clauses are given and provisions are provided for sifting of burden of proof. In socio-economic offences when prohibited act is proved, presumption is made regarding mens rea thereby about commission of crime and in such case naturally burden of proof for mens rea will not be of prosecution but sifts on the accused. Further, in some Special Penal Act specific provision for sifting of burden of proof also provided. Sections 4 and 5 CrPC clearly provide that when special procedure is provided in Special Penal Act that shall be applicable, general procedure shall be applicable only when special

${ }^{21}(2002) 3$ SCC 598. 
procedure is not provided. ${ }^{22}$ When accusation is made for commission of socioeconomic crime and some materials are available regarding actus reus then presumption is made regarding crime commission. Hereby case is prima facie established and in such situation normally bail is rejected. Further, for socioeconomic offences preventive detention laws are also enacted to keep the offender in custody for longer period for collection of evidences, to protect evidence, prevent repeat of crime and ultimately effective investigation.

Section 8-A of Dowry Prohibition Act 1961 imposes burden of proof on person who is alleged for taking or abetting the taking of dowry or demanding dowry; Section 4 of Drugs and Cosmetics Act 1940 provides for presumption about substances as poisonous substances. In Section 34 of Drugs and cosmetics Act 1940, Section 9 of Drugs and Magic Remedies (Objectionable Advertisement) Act 1954, Section 10 of Essential Commodities Act 1955, Section 42 of Foreign Exchange Management Act 1999, Section 7 of Indecent Representation of Women (Prohibition) Act 1986, Section 70 of Prevention of Money Laundering Act 2002, Section 56 of Black Money (undisclosed Foreign Income and Assets) Act 2015, Section 62 of Benami Transactions (prohibition) Amendment Act 2016 presumption clauses are provided when offence is committed by company it is presumed as also committed by in charge of company, director, manager and secretary of company. In Section 10 - C Essential Commodities Act 1955 presumption of culpable mental state is provided according to which the court shall presume mental state of the accused for those offences under the Act for which mental state is required but it will be rebuttable presumption. In Section 13 presumption about issued order is given and Section 14 of Essential Commodities Act sifts burden of proof on the accused. In Section 39 of Foreign Exchange Management Act 1999 prescribes presumption regarding genuineness of document, signature on document and contents of document. In Section 54 of Black Money (undisclosed Foreign Income and Assets) Act 2015 makes presumption regarding culpable mental state of the accused; it is rebuttable presumption as in provision accused is permitted to take defence that he was not having such mental state therefore mental state shall be presumed but then after the accused will be provided opportunity to give his own evidences to show that he did not have such mental state. Section 20 of prevention of corruption Act 1988 provides that when public servant has taken any undue advantage from any person then it shall be presumed that he took undue advantage as motive or reward under section 7 of the Act and his presumption is rebuttable presumption. Whenever in criminal case presumption is made, with proving of prohibited act prima facie establishes role in crime commission. Further, thereby burden of proof sifts, now there is no necessity to prove the presumed fact by prosecution but requires

\footnotetext{
${ }^{22}$ Section 4(2) CrPC provides: "All offences under any other law shall be investigated, inquired into, tried, and otherwise dealt with according to same provisions, but subject to any enactment for the time being in force regulating the manner or place of investigating, inquiring into, trying or otherwise dealing with such offences." Section 5 CrPC provides: "Nothing contained in this Code shall, in the absence of a specific provision to the contrary, affect any special or local law for time being in force, or any special jurisdiction or power conferred, or any special form of procedure prescribed by any other law for the time being in force."
} 
disproving by the accused. In some Acts burden of proof is expressly provided. In such cases with allegation case is prima facie established therefore bail is normally not provided. Generally provision relating to bail is not given in special penal statutes. In such situation according to section 4 (2) CrPC bail is granted to the accused under provisions of Criminal Procedure Code which has well established rule that in prima facie established case normally bail should not be granted. Due to presumption and burden of proof clauses in Economic Offences criminal case is prima facie established therefore normally bail is rejected.

In Prevention of Money Laundering Act (PMLA) 2002 special provision is given $\mathrm{u} / \mathrm{s} 45$ directing consideration of some aspects in granting bail to person accused under PMLA. PMLA is a special statute and further section 45 PMLA starts with non-obstante clause thereby it is clear that provisions contained in section 45 PMLA shall prevail over general provisions of Criminal Procedure Code in case of conflict between them. Section 4 (2) and 5 of Criminal Procedure Code prescribe that in case of special penal statute special procedure provided in that Act shall prevail over procedure given in Criminal Procedure Code. Further, similar provisions are given in section 65 and 71 of Prevention of Money Laundering Act. Section 65 prescribes that provisions of $\mathrm{CrPC}$ shall apply so far as they are not inconsistent with the provisions of PMLA and section 71 prescribes that provisions of the PMLA shall have overriding effect notwithstanding anything contained in any other law for the time being in force. PMLA has overriding effect and the provisions of CrPC may apply only when they are not inconsistent with PMLA. Therefore in granting bail section 45 of PMLA prevails over provisions of bail contained in Criminal Procedure Code. Section 439 of $\mathrm{CrPC}$ shall be applicable only with due compliance of section 45 PMLA. Section 45 of Prevention of Money Laundering Act requires satisfaction of three conditions for grant of bail to any accused person alleged for offence punishable under PMLA

1. Prosecutor must be given an opportunity to oppose the application for bail;

2. The Court must be satisfied that there are reasonable grounds for believing that the accused person is not guilty of such offence; and

3. He is not likely to commit any offence while on bail. ${ }^{23}$

\footnotetext{
${ }^{23}$ Section 45 (1) PMLA 2002 Provides: "Notwithstanding anything contained in the Code of Criminal Procedure, 1973, no person accused of an offence under this Act shall be released on bail or on his own bond unless -

(i) The Public Prosecutor has been given an opportunity to oppose the application of such release; and

(ii) Where the Public Prosecutor opposes the application, the Court is satisfied that there are reasonable ground for believing that he is not guilty of such offences and that he is not likely to commit any offence while on bail; provided that a person who is under the age of sixteen years or is a woman or is sick or infirm or accused either on his own or along with other co-accused of money-laundering a sum less than one crore rupees, may be released on bail, if special court so directs..."
}

Section 45 (2) PMLA Provides: "The limitation on granting of bail specified in sub-section (1)is in addition to the limitation under the Code of Criminal Procedure, 1973 (2 of 1974)or any other law for time being in force on granting bail." After Nikesh Tarachand Shah case Section 45 (1) PMLA is applicable for offence punishable in PMLA. In P. Chidambaram v. Directorate of Enforcement the Court observed that for section 45 there are prior and post Nikesh Tarachand Shah situations. 
It is clear from provisions that bail considering the court before disposal of bail petition should be satisfied regarding prima facie situation of the case and further, regarding probability of repetition of crime. For this purpose public prosecutor is given opportunity of hearing. When case is prima facie established or there is probability of repetition of crime, bail is denied.

Gautam Kundu v. Manoj Kumar, Assitant Director, Eastern Region Directorate of Enforcement (Prevention of Money Laundering Act) Govt. of India 24 case was relating to Rose Valley Chit Fund case. Appellant was chairman of Rose Valley Real Estate Construction Ltd. The accused floated many companies, allured investments and subsequently drained off money to associated companies. He was accused of commission of offences under section 3 and 4 of PMLA and section 24 of SEBI Act. Section 24 SEBI Act is schedule offence under Paragraph 11 of the Schedule of PMLA. In this case the High Court granted Temporary Bail (Provisional Bail) for 2 weeks for performance of rituals for his deceased father. Within due time the accused surrendered before Court and then after moved the Calcutta High Court for grant of regular bail u/s 439 CrPC. The High Court rejected the bail petition. The accused filed appeal before the Supreme Court. The Supreme Court decided that PMLA has special provision for bail and whenever bail is considered $\mathrm{u} / \mathrm{s} 439 \mathrm{CrPC}$, it is necessary that requirement of section 45 PMLA must be satisfied. The Supreme Court observed that at this stage it is not expected to establish guilt of the accused beyond reasonable doubt through evidences but some propositions should be considered that

1. Economic Offences cause huge loss to public fund which affect the economy of country as a whole and thereby posing serious threat to the financial health of country; and

2. Allegations may not ultimately be established, but the burden of proof that the monies were not proceeds of crime and were not therefore tainted money sifted on the accused persons under section 24 of the PMLA 2002. In case of economic offences there is always probability to repeat crime. The Supreme Court upheld decision of High Court.

Previously bail related provisions provided in section 45 PMLA was applicable for offences punishable by more than three years punishment under Part - A of Schedule of PMLA. Section 45 (1) was providing before 2018 that - " Notwithstanding anything contained in the Code of Criminal Procedure , 1973, no person accused of an offence punishable for a term of imprisonment of more than

Previously bail provision u/s 45 PMLA was applicable for offences punishable by more than three years imprisonment mentioned under Part - A of schedule and then twin conditions were given. In Nikesh Tarachand case the Supreme Court declared twin conditions as unconstitutional on the basis of discrimination. In 2018 amendment was made through Finance Act 2018 which made section 45 applicable for all the offences under PMLA. This amendment removed effect of Nikeh Tarachand Shah case decision by rectifying the ground for applicability of provision relating to bail. Amendment 2018 enabled the court to release person on bail when money laundering is of less than one crore rupees which in addition to categories already provided - child below sixteen years, woman, sick and infirm.

${ }^{24}$ AIR 2016 SC 106. 
three years under Part - A of the Schedule shall be released on bail..." and then in two clauses conditions were imposed. According to which release on bail was generally difficult when offence was punishable by more than 3 years imprisonment under Part - A of PMLA. It means for offences punishable under PMLA twin conditions mentioned in section 45 were not applicable while these conditions were applicable on proceed of crime obtained by commission offences punishable under some other Acts mentioned in Part - A of PMLA. It was making differential situation that for offences under PMLA for granting bail provisions of Criminal Procedure were applicable while for offences punishable under some other Act mentioned in Part - A of Schedule of PMLA section 45 of Act was applicable. In Nikesh Tarachand Shah v. Union of India ${ }^{25}$ the Supreme Court decided that twin conditions imposed under section 45 (1) (ii) PMLA

1. Reasonable ground for believing that the accused is guilty

2. The accused is likely to commit any offence, are unconstitutional as these violate Articles 14 and 21 of Constitution.

When a person is charged for offence punishable under PMLA simply his case may be dealt $\mathrm{u} / \mathrm{s} 439$ while if for same proceed of crime, charge is for offence under Part - A of schedule of PMLA, then primarily section 45 PMLA will be applicable and twin conditions will become applicable. The Court decided that such classification is arbitrary and further it violates Article 21. The Court decision in Nikesh Tarachand Shah Case clears that if Section 45 would have provided applicability for offences under PMLA instead of offences punishable for a term of imprisonment of more than three years under Part-A of the Schedule of PMLA, it would not be unconstitutional. In 2018 through amendment provision, which was inserted through Finance Act 2018, section 45 has been made applicable for all offences punishable under PMLA. Now section 45 PMLA does not make differentiation between offences under Part - A of schedule and other offences under the Act. When offence is under PMLA then section 45 shall be applicable and it will prevail over section 439 of Criminal Procedure Code. Amendment 2018 enables the court to release person on bail when money laundering is of less than one crore rupees which is in addition to one category already provided - category of accused that he is child below sixteen years, woman, sick or infirm person. There are two categories of cases in which bail may be granted one on the basis of extent of proceed of crime and other by nature of the accused. By extent of proceed of crime differentiation is made between money laundering of lesser amount that is less than one crore and of more amount that is one crore or more. This condition provides more stringent situation for refusal of bail in cases of smuggling, drug peddling, terrorism, black money and other acts affecting financial wellbeing of country. When proceed of crime is less than one crore bail may be granted but where proceed of crime is of one crore or more bail shall be refused on proving of twin condition provided in section 45 of PMLA. By Finance Act 2019 one explanation has been added to clarify that all the offences under PMLA are cognizable and non-bailable notwithstanding anything to the contrary

\footnotetext{
${ }^{25}$ https://indian kanoon.org/doc/117859307/2.26.2020.
} 
contained in the Code of Criminal Procedure. Thereby investigating agency is empowered, in case of any offence punishable under the PMLA, to arrest without warrant as per provision given in section 19 and then bail shall be decided as per provision given under section 45 of PMLA and thereby providing opportunity of hearing to public prosecutor is mandatory and when on this hearing the court has reasonable ground of believing that the accused has committed offence under the Act or there is fear of repeat of crime, the Court shall not grant bail.

In Section 37 of Narcotic drugs and Psychotropic Substances Act (NDPS Act) 1985 similar provision as given in Section 45 of PMLA is provided. Under section 37 of NDPS Act, when a person is accused of an offence under Section $19^{26}$ or $24^{27}$ or $27-\mathrm{A}^{28}$ and also offences involving commercial quantity ${ }^{29}$, it is provided that he shall not be released on bail unless Public Prosecutor has been given an opportunity of hearing; on such hearing the court is satisfied that there is reasonable ground for believing that the person is not guilty of the alleged offence and that he is not likely to commit any offence while on bail. These limitations are in addition to those prescribed under the $\mathrm{CrPC}$ or any other law for time being in force on the grant of bail. In Section 45 of PMLA permission is given that the court may give bail to younger person below 16 years age, woman sick or infirm person but such relaxation is not prescribed in Section 37 of NDPS Act. Section 19, 24, 27-A and commercial quantity are relating to drug peddling. Drug peddling is most serious offence which affect the youth of the society and further offenders are prone for repeat of crime which is not simple crime but most disastrous one. In Satpal Singh v. State of Punjab ${ }^{30}$ the Supreme Court observed that offences under NDPS Act are of serious nature about which law makers were conscious and consciously put stringent restrictions on discretion available to the court while considering application for release on bail. The Court reminded police and prosecutor that they need to show due diligence and vigilance while dealing with the cases under the NDPS Act. In this case three brothers were alleged for commission of offences under NDPS Act. Two co-accused persons were granted

\footnotetext{
${ }^{26}$ Section 19 NDPS Act prescribes punishment when licensed cultivator commits embezzlement or otherwise illegally disposes opium produced. This offence is punishable with minimum ten years and maximum twenty years rigorous imprisonment. Fine is also mandatory- minimum 1 lakh rupees and maximum 2 lakh rupees. The Court may impose fine more than 2 lakh rupees for reason to be recorded.

${ }^{27}$ Section 12 NDPS Act puts prohibition on obtaining narcotic drugs and psychotropic substances outside country or supply it outside country except with the previous authorization and conditions by the Government. This provision attempts to illicit drugs dealing in other country. It is responsibility of country that not only drug peddling should be dealt in our country but also to see that citizen are not engaged in such act in other country. Violation of prohibition u/s 12 is declared as offence u/s 24 punishable with minimum ten years and maximum twenty years rigorous imprisonment. Fine is also mandatory- minimum 1 lakh rupees and maximum 2 lakh rupees. The Court may impose fine more than 2 lakh rupees for reason to be recorded.

${ }^{28}$ Section 27-A NDPS Act prescribe punishment for financing illicit traffic and harbouring offenders. Punishment prescribed is same as provided in Section 19 and 24 of NDPS Act.

${ }^{29}$ Section 2 (viia) NDPS Act defines commercial quantity according to which illicit substance quantity is greater than the quantity specified by the Central Government by notification in Official Gazette. When a person has commercial quantity, it is indicative that he is not drug addict but he is drug peddler.

${ }^{30}$ AIR 2018 SC 2011.
} 
bail. Now another accused filed petition for grant of anticipatory bail. The Supreme Court opined that in NDPS Act section 37 is mandatory provision and prevail over general provisions of bail under CrPC. the quantity of contraband recovered was commercial and in such situation regular or anticipatory bail without reference to Section 37 of NDPS Act cannot be given. The Court set aside all the bail orders and directed the accused persons to surrender before the trial court with liberty to move petition for regular bail.

Socio-economic offences are serious problem for wellbeing of society and societal members. To tackle problem in these cases presumption clauses are provided thereby case is presumed as prima facie established. Further, in some special Act specific provisions are contained to direct the courts to consider prima facie situation in the case in the disposal of bail application. When case is prima facie established bail is not granted.

\section{Concluding Remarks}

Socio-economic crimes affect the health, life, development and economic wellbeing of whole society and members of society. Socio-economic criminal is a person with respectability, status, position, and means. His modus operandi of commission of crime is completely different; he commits crime in organised and planned manner with deep conspiracies. Socio-economic criminal in crime commission uses modern know-how and modern gadgets. Socio-economic crimes, socio-economic criminal and its impacts are completely different from traditional crimes. To tackle socio-economic criminal activity there is need to change the traditional concepts of criminal justice and one such concept needed to be changed is -'bail is rule and jail is exception'. In socio-economic offences for effective investigation, avoiding obstruction in investigation and pressure on investigating officer, protection of witnesses and evidences, and prevention of repeat of crime it is better that the accused should remain in jail as under-trial prisoner till disposal of case or at least till prosecution has adduced its evidences. Liberty of person is crucial and fundamental; there should not be unnecessary interference with it. Without proper liberty a civilised society cannot exist. Therefore, to make balance between these two contrary things further there should provision for effective but speedier investigation and trial in socio-economic offences and for this purpose specialised expert investigating and prosecuting bodies should be established. Investigating agencies should have modern gadgets, labs, technicians and training to effectively and speedily deal with socio-economic crime. Socio-economic crimes should be dealt differently from traditional crimes. In traditional crimes bail granting may be normal course but in socio-economic bail can only be given exceptionally. Protection of society is more important than some problem and suffering to an individual. 


\section{References}

\section{Legislation}

The Constitution

Criminal Procedure Code

Benami Transactions (prohibition) Amendment Act 2016

Black Money (undisclosed Foreign Income and Assets) Act 2015

Dowry Prohibition Act 1961

Drugs and Cosmetics Act 1940

Drugs and Magic Remedies (Objectionable Advertisement) Act 1954

Essential Commodities Act 1955

Foreign Exchange Management Act 1999

Indecent Representation of Women (Prohibition) Act 1986

Narcotic drugs and Psychotropic Substances Act 1985

Prevention of Money Laundering Act 2002

\section{Cases}

Anil Kumar Tulsiyani v. State of UP 2006 (5) SCALE 233

Babu Singh v. State of Uttar Pradesh AIR 1978 SC 527

Bhadresh Bipinbhai Sheth v. State of Gujarat AIR 2015 SC 3099

Bharat Stars Services Pvt. Ltd. v. Harsh Dev Thakur AIR 2019 SC 718

Gautam Kundu v. Anoj Kumar, Assitant Director, Eastern Region Directorate of Enforcement (Prevention of Money Laundering Act) Govt. of India AIR 2016 SC 106

Gudikanti Narasimhulu v. Public prosecutor AIR 1978 SC 429

Gurubux Singh Sibia v. State of Punjab Case AIR 1980 SC 1632

Himanshu Chandravadan Desai v. State of Gujrat AIR 2006 SC 170

Hussainara Khatoon v. State of Bihar AIR 1979 SC 1360

Mrs Leena Mahesh v. Republic of India http://Indiankanoon.org/oc/59681/

Neeru Yadav v. State of Uttar Pradesh AIR 2015 SC 3703

Nikesh Tarachand Shah v. Union of India https://indiankanoon.org/doc/117859307/ 2.26.2020

P. Chidambaram v. Central Bureau of Investigation https://indiankanoon.org/oc/1828527 $74 / 2 / 24 / 2020$

P.Chidambaram v. Directorate of Enforcement https://indiankanoon.org/doc/90251163/2/ 24/2020

Rajesh Ranjan Yadav @ Pappu Yadav v.CBI through Its Director AIR 2007 SC 451

Ram Govind Upadhyay v. Sudarshan Singh(2002) 3 SCC 598

Satpal Singh v. State of Punjab AIR 2018 SC 2011

State of Bihar v. Amit Kumar AIR 2017 SC 2487

State of Gujarat v. Mohanlal Jitamalji Porwal (1987) 2 SCC 364

State of Rajasthan v. Balchand AIR 1977 SC 2447

State of UP v. Amarmani Tripathi (2005) 8 SCC 21

Sudhir v. State of Maharashtra AIR 2015 SC 3665 



\title{
The Current Trends in the Right of Assembly under the European Convention on Human Rights
}

\author{
By Petr Černy"
}

\begin{abstract}
The right of assembly is one of the most important political rights. This right, together with freedom of speech and the right to associate, is the basis of every civil society. In particular, it enables everyone to comment on public affairs, get information, share it with other people, and also influence public opinion. This right is especially important in times of social changes. The European Court of Human Rights (ECHR), seated in Strasbourg, protects compliance for the European Convention on Human Rights and assesses, inter alia, whether the member states violated the right of free assembly. The application of article 11 of the Convention raises a number of questions about the scope of the possibility to restrict the right of assembly. Member States of the Convention sometimes face the question whether to ban the assembly of the enemies of democracy or whether the right of assembly can be abuse to prevent other assemblies by blocking the route of march, for example. This paper deals with the ECHR's approach to these issues as well as the concept of right of assembly according to the Convention. At the same time it follows the evolution of the opinion on this right over time.
\end{abstract}

Keywords: European Convention on Human Rights; European Court of Human Rights; Freedom of Speech; Property Law; Right of Assembly.

\section{Introduction}

The right of assembly is considered one of the fundamental rights and is guaranteed in both the constitutional documents of European states and in Article 11 of the European Convention on Human Rights (hereinafter referred to as 'the Convention'):

1. Everyone has the right to freedom of peaceful assembly and to freedom of association with others, including the right to form and to join trade unions for the protection of his interests.

2. No restrictions shall be placed on the exercise of these rights other than such as are prescribed by law and are necessary in a democratic society in the interests of national security or public safety, for the prevention of disorder or crime, for the protection of health or morals or for the protection of the rights and freedoms of others. This article shall not prevent the imposition of lawful restrictions on the exercise of these rights by members of the armed forces, of the police or of the administration of the State.

\footnotetext{
*Assistant Professor, Faculty of Social and Economy Studies, University Jan Evangelista Purkyně, Czech Republic. E-mail: petr.cerny@ ujep.cz
} 
The European Court of Human Rights (hereinafter referred to as 'ECHR') interprets the rights enshrined in the Convention and provides member states with a basic framework of the level of human rights.

Historically, the right of assembly in continental Europe originated in the $18^{\text {th }}$ century as a purely political right along with other political rights. It was about gaining the opportunity for citizens to speak together at the assembly against the absolutist state. Initially, political parties emerged as the most socially influential organizations in the execution of the right of assembly, and only in the last few decades other social movements that are not oriented towards seizing power in the state, have emerged.

In a current democratic state (as opposed to an absolutist, totalitarian or autocratic state), this freedom as well as other freedoms is taking on a broader dimension which allows them, with regard to the possibility of creation of public opinion, to discuss and address all issues which are of major importance for society. This makes the right of assembly one of the structural elements of democracy. This situation is also reflected in the Convention, in which the right of assembly is not described as a political right, and its interpretation applies the protection of assemblies even to completely non-political assemblies.

The right of assembly often also serves to informal control of the exercise of power in the state, to the possibility to express oneself critically towards representatives of public life. Sometimes the assembly is the only effective way of expressing for certain groups of the population, or representatives of minority views in general, who do not have access to the media or at least enough funds to spread their ideas. The assembly gives a certain added value to the expressed opinion, because the presence of a certain number of people at a particular place strengthens the weight of the expressed attitude and gives it a certain emotional dimension.

\section{Relation to the Freedom of Expression}

The right of assembly is closely related to freedom of expression, which is a central political right. Due to the interpenetration with other rights we can call it the universal right or super-freedom. Without the opportunity to express ideas or opinions the other political rights would be meaningless. What good would the possibility to gather with others be to the person if they could not express common views? If freedom of expression cannot be restricted in a certain area (e.g. only because shocking and offensive ideas are presented), freedom of assembly cannot be restricted for this reason either. The right of assembly is one of the important rights by which freedom of expression is exercised.

Without freedom of expression, it is difficult to imagine participating in the solution of public issues and problems, participating in elections or the possibility of obtaining information without being able to disseminate them further. Freedom of expression is one of the most important foundations of a democratic society and one of the main conditions for its progress and the development of any individual. 
Article 10 of the Convention guaranteeing freedom of expression does not provide for specific forms of expression, from which it is possible to deduce the possibility to express oneself in all forms imaginable. One is therefore free to express himself in writing, orally, in print, in images, by symbolic actions, such as wearing a uniform, by songs, by music, by different types of clothing, etc. The speech does not have to necessary relate directly to participation in political issues.

According to the ECHR, freedom of assembly and the right to express opinions through it are among the overriding values of a democratic society. According to the ECHR, freedom of assembly must also be interpreted with regard to the exercise of freedom of expression, since the right to hold opinions and the right to disseminate those opinions are an integral part of freedom of assembly ${ }^{1}$. In some judgments, the ECHR even goes so far as to explicitly mention that it has interpreted Article 11 of the Convention in the present case in the light of Article 10 of the Convention ${ }^{2}$. It should also be noted that the ECHR considers the right of assembly to be a lex specialis to freedom of expression, as it may also interfere with the right of assembly without interfering with freedom of expression. This will be the case when there is a ban on the assembly before its realisation or in the case of the organization of an unauthorised assembly ${ }^{3}$. On the other hand, in the case of a ban on the assembly for chanting certain slogans and opinions, it will interfere with both rights ${ }^{4}$.

The ECHR often states in its decisions that the essence of democracy is its ability to solve problems through open discussion. Radical preventive measures that suppress the right of assembly and freedom of expression in cases other than incitement to violence or rejection of democratic principles - as shocking and unacceptable some views and words may seem to state authorities, and as illegitimate the demands may be, they render a disservice to democracy and often even threaten it. In a democratic society based on the rule of law, political ideas which call into question the existing order and the implementation of which is advocated by peaceful means must be given a fair opportunity to express themselves through the exercise of the right of assembly as well as other legal means. If any likelihood of tensions or intense communication between opposing groups during the event were to justify banning it, society would be deprived of the opportunity to hear differing views on any issue that offends majority opinion ${ }^{5}$.

The right of assembly is therefore one of the ways in which minorities in society, which may not be accepted by the majority society, can present and express themselves. One example is the case of Alexeyev v. Russia solved by the $\mathrm{ECHR}^{6}$. In this case gay community marches were banned to alert the public to discrimination against this minority in Russia (the marches were called either Pride March or Gay Pride). Moscow municipal authorities have banned these assemblies, with reference to violations of the rights of others, namely those who

\footnotetext{
${ }^{1}$ Refah Partisi and Oth. v. Turkey (2003); Öllinger v. Austria (2006).

${ }^{2}$ Sergey Kuznetsov v. Russia (2008); Körtvélyessy v. Hungary (2016).

${ }^{3}$ Kudrevičius and Oth. V. Lithuania (2015).

${ }^{4}$ Cf. Ezelin v. France (1991), Galstyan v. Armenia (2007), and Barraco v. France (2008).

${ }^{5}$ Pilot judgment of ECHR Stankov and the United Macedonian Organisation Ilinden v. Bulgaria (2001).

${ }^{6}$ Alexeyev v. Russia (2010).
} 
have a negative attitude toward homosexuality out of religious or moral beliefs. They argued that the state must also consider the requirements of major religious associations that demanded a ban on assemblies. In the ruling, the ECHR pointed out that the mayor of Moscow had repeatedly publicly expressed his determination to prevent gay marches, because the promotion of homosexuality should be according to him incompatible with the religious doctrines and moral values of the majority. The ECHR stated, inter alia, that democracy did not mean that the opinion of the majority must always prevail and that only the moral values of officials were reflected in the ban on assemblies, so it did not consider the ban on marches necessary in a democratic society and delivered a ruling on violation of Article 11 of the Convention.

However, the ECHR grants freedom of expression as well as freedom of assembly different degrees of protection depending on the purpose and area of public life in which these rights are to be exercised. It attaches the great importance to the freedom of expression in the political debate and considers that only very compelling reasons are needed to justify a restriction on political expression ${ }^{7}$. Political expression can be defined relatively broadly as an expression of a person's will to participate in solving public problems or to express an attitude towards certain issues of general interest.

Furthermore, it is important to realise that freedom of expression in connection with the right of assembly are not unrestricted and are not intended to intimidate groups of the population or opponents in opinions, but primarily to address societal issues. In this connection the judgment in Vona v. Hungary ${ }^{8}$ can be recalled, which involved dissolution of the far-right civic association (Hungarian Guard Movement). This association organised demonstrations and marches in places with a significant Roma population with participants numbering tens to hundreds of people evoking in their clothing, symbols and speeches and slogans the fascist regime of the Arrow Crosses governing in Hungary in the 1940s. The activities and manifestations of this movement were verbally and visually based on the racially based distinction between the Roma minority and the Hungarian majority. Referring to previous case law the ECHR has stated that as in the case of freedom of expression, ideas or actions cannot be excluded from the protection of the Convention simply because they raise concerns in a certain group of people or are perceived by some as disrespectful. However, the court noted that although there was no immediate violence in the marches organised by the movement, the marches were capable of expressing the intention and ability of their organisers to use the paramilitary group for achieving the objectives that evoked the Arrow Crosses as a pillar of the regime responsible for mass massacre of Roma in Hungary. The ECHR further considered that the effect of these marches was enhanced by the association's connection with the Hungarian Guard Association as a registered association enjoying legal recognition. In the light of Hungary's historical experience, speeches during demonstrations and marches could intimidate a racial minority, especially when their members were witnesses in their

\footnotetext{
${ }^{7}$ Feldek v. Slovakia (2001).

${ }^{8}$ Vona v. Hungary (2013).
} 
homes as involuntary audiences. According to the ECHR, such conduct does not enjoy the protection of the Convention.

Another important rule in the application of the Convention follows from the ECHR case law, namely that illegal activities and manifestations that occur at the assembly cannot be attributed indirectly to the organisers of the assembly, unless it is proven that the individuals concerned were directly involved in these activities?

Reference may be made to the case of Štefanec v. Czech Republic ${ }^{10}$ were assembly was organised even after it was prohibited after proper notification (by a person other than Mr. Štefanec). It was proven that Mr. Štefanec led the procession and communicated with the police and the participants of the assembly through a megaphone. Provisions of national law made it possible, inter alia, to penalise those who convene or hold a prohibited assembly. Mr. Štefanec denied that he was the convener or organiser of the assembly. It follows from the ECHR judgment that only the declaration of a person as an organiser is not sufficient, but it is necessary to prove that this person actually took care of the course of the meeting, organised it and directed its course. In the given case, the key evidence were video recordings from the assembly, however, they were not sufficient to prove that $\mathrm{Mr}$. Stefanec, for example gave instructions to move the assembly, etc.

\section{The Term of Assembly}

One of the key issues in the application of the Convention is the definition of assembly and the resulting protection granted by the Convention. Where an assembly can be defined as an assembly under Article 11 of the Convention, it follows that the assembly is under increased protection against interference of the State and third parties, which must respect the application of this fundamental right. Conversely, unless it is an assembly under the protection of the Convention, it may be restricted by ordinary legal prohibitions. Such case may be an assembly of witnesses to a traffic accident or a queue in front of a shop, etc. These assemblies may be dissolved or otherwise restricted through ordinary police law.

Assemblies within the meaning of the Convention are generally considered to be both private and publicly accessible assemblies of persons, as well as street processions, i.e. assemblies not limited to one place, whose participants have a common goal. While applying Article 11 of the Convention, the ECHR is based on the concept of 'assembly' as a grouping of many individuals, processions, and public parades in a peaceful form. The term assembly under the Convention includes prolonged occupation of buildings ${ }^{11}$, political, religious ${ }^{12}$, cultural $^{13}$,

\footnotetext{
${ }^{9}$ Yilmaz and Kiliç v. Turkey (2008).

${ }^{10}$ Štefanec v. Czech Republic (2006).

${ }^{11}$ Cissé v. France (2002).

${ }^{12}$ Barankevich v. Russia (2007).

${ }^{13}$ Gypsy Council v. UK (2002).
} 
social, or other gatherings, including exhibitions, concerts, trade fairs, seminars, and receptions ${ }^{14}$.

It should be recalled here that Article 11 of the Convention protects only peaceful assemblies. This means, among other things, that the assembly is not convened for the purpose of committing violence, riots, and other illegal acts or that these activities are not organised by the convener or another person (organiser) during the meeting. Minor incidents during the assembly do not make the assembly restless ${ }^{15}$.

The occupation of buildings as a form of assembly is undoubtedly one of the most disputable forms of assembly, as there is a sharp conflict between property rights and the right of assembly. Here comes the question of how to deal with an assembly that intentionally occupies someone else's property (so-called squatting). The fundamental question is whether such an event is an assembly and whether it is protected by Article 11 of the Convention. This action often involves people demonstratively occupying abandoned buildings, posting political statements, or even holding supportive actions in them, and refusing to leave an occupied building even by means of passive resistance. Thus, it is obviously not a simple squatting consisting in obtaining housing in abandoned properties, but at the same time a civically active attitude presented externally.

One of the means of keeping a property occupied is to declare its new inhabitants to be participants in the assembly, who are demonstrating a socially important topic by their action. Since only peaceful assemblies enjoy constitutional protection, if violence is used when entering the building (breaking of locks, etc.), this action cannot be subsumed under the protection of the right of assembly.

The ECHR judgment in Cissé v. France ${ }^{16}$ is often mentioned in this context. In this case, however, it was a specific situation. With the consent of ecclesiastical authorities, French immigrants occupied and inhabited the French church for a long time to draw attention to the disproportionately strict French immigration laws and called for their change. Following the worsening of the hygiene situation, the assembly was dissolved by the French police, which the ECHR found to be a legitimate reason for ending the assembly.

With the changes in society and its development, new questions arise regarding the choice of the place where the assembly can take place, and there are further conflicts between the right of ownership and the right of assembly. In Appleby v. The United Kingdom ${ }^{17}$, the complainants argued that they could not hold a meeting in a city shopping centre belonging to a private individual. However, this centre was first built by a legal entity established by the city, which then transferred the centre to private hands. The complainants argued that the shopping centre was not only a shopping centre, but also a social centre where people met, and had several other functions. In this case, the ECHR considered

\footnotetext{
${ }^{14}$ Djavit An v. Turkey (2003); /92; Bączkowski and Others v. Poland (2007); Sergey Kuznetsov v. Russia (2008); European Commission of Human Rights decision in Rassemblement Jurassien Unité Jurassienne v. Switzerland (1970).

${ }^{15}$ European Commission of Human Rights decision in Christians against Racism and Fascism v. UK (1980); Stankov and United Macedonian Organisation Ilinden v. Bulgaria (2001).

${ }^{16}$ Cissé v. France (2002).

${ }^{17}$ Appleby v. UK (2003).
} 
that the centre is marked on maps as an urban centre providing several other services and participating in the cultural and social life of the city. The ECHR stated that due to democratic, social, economic and technological developments, a positive obligation of the state may arise to enforce exercising of the right of assembly also towards a private entity, especially if it is a private entity in some way connected with a public institution. However, in the present case, he considered that the complainants had ample opportunities to exercise their right of assembly without restricting private property, as they could demonstrate (set up an information stand) at the centre's entrances, on its galleries or negotiate with individual traders within the centre, they could also hold their meetings in the old city centre, which is why the ECHR did not find there a positive obligation from the state and a violation of Article 11 of the Convention.

This judgment can also be approached relatively critically, with reference to the development of society and the real privatization of several public services provided so far by the state, such as transport, post, energy supply, and healthcare. The question is whether, even in this situation, property rights should prevail over other rights and whether the state should ensure a fair balance of these rights. In this case, there was no doubt that the premises were set up from public funds and, even after being transferred to private hands, served as a quasi-public space (forum publicum). In this project, that was transferred to private hands as a new building, public money and public interests were present. This centre was located near public institutions. It is difficult to accept the view that, through privatization, public authorities will be relieved of their responsibility to meet the needs of the population and to ensure the realization of fundamental human rights and freedoms. In the current conditions, the view that the private owner can expel anyone from his land indefinitely is completely unsustainable.

We can therefore state that the assembly can also take place inside the building, but the right of assembly itself does not automatically entitle the occupation of third-party property. In general, there is no right to choose a forum where persons would like to exercise their right of assembly, if it can be exercised elsewhere. However, there is a relevant number of views, also presented in the ECHR case law, that in certain cases the right of ownership has to give way and is not inherently unlimited, but when this is to happen has not yet been comprehensively and satisfactorily resolved.

With regard to the purpose of the assembly for which the assembly is held, the ECHR, on the one hand, acknowledges that the official purpose of the assembly may be different from the actual (illegal) one, but immediately adds that these facts need to be verified in practice, i.e. how subject is going to behave $\mathrm{e}^{18}$. It is not possible to deduce from the case law of the ECHR a tendency to preventive prohibitions of assemblies before their holding, if the declared purpose of the assembly is harmless. Nor can the ban on an assembly be based solely on the fact that in the past some participants in the assembly were violent ${ }^{19}$.

\footnotetext{
${ }^{18}$ Stankov and the United Macedonian Organisation Ilinden v. Bulgaria (2001); Tsonev v. Bulgaria (2006).

${ }^{19}$ E.g. Primov and Oth. v. Russia (2014).
} 
However, the ECHR allows for the establishment of restrictive conditions for hold of an assembly, including the obligation to notify the assembly in advance to balance the various interests protected. Regarding the announcement of the assembly, the ECHR stated that since the assembly in a public place could in some way disrupt everyday life and may face disapproval, it is important that the organiser of the assembly complies with the rules laid down by law for announcing the assembly. In addition, such an obligation is also to the benefit of the participants in the assembly, as the notification of the assembly in advance allows the police to prepare for the event and to ensure its smooth running ${ }^{20}$. Although a number of legal regulations of European states (e.g. German, Austrian, Polish, Czech, Slovak) contain the reporting principle of the Assembly, which means that it is sufficient to report the intention of holding as assembly to the authority, in accordance with the Convention is the authorization principle consisting in the possibility to hold the assembly only after the authority has granted permission to hold it (e.g. Russian, Lithuanian) ${ }^{21}$.

\section{Interventions in the Right of Assembly}

Another major issue of the right of assembly is the question of what interventions in the right of assembly are permissible and under what conditions they can be carried out. Article 11 of the Convention foresees three cumulative conditions which justify an interference with the right of assembly, namely (a) the interference must be effected by law; (b) it must pursue one of the legitimate objectives set out in Article 11 (2) of the Convention; and (c) it must be necessary in a democratic society, that is, proportionate to the objectives it pursues.

State interference in the right of assembly can take many different forms. The most common type of intervention is a ban on the assembly before it takes place ${ }^{22}$ and the dissolution of the assembly during the assembly ${ }^{23}$. However, the ECHR has described in its case law several other interventions as interfering with the right of assembly. These included, for example, criminal sanctions against demonstrators $^{24}$, detention at a police station $^{25}$, imposition of a fine in administrative proceedings ${ }^{26}$, restriction of the date of the meeting or place of the meeting ${ }^{27}$, diversion of the meeting to another place ${ }^{28}$ or evacuation of the church in case of its occupation ${ }^{29}$.

\footnotetext{
${ }^{20}$ Barraco v. France (2009); Oya Ataman v. Turkey (2006).

${ }^{21}$ Sergey Kuznetsov v. Russia (2008).

${ }^{22}$ Bączkowski and Oth. v. Poland (2007).

${ }^{23}$ Akgöl and Göl v. Turkey (2011); Primov and Others v. Russia (2014).

${ }^{24}$ Yilmaz and Kiliç v. Turkey (2008); Kudrevičius and Others v. Lithuania (2015); Kakabadze and Oth. v. Georgia (2012).

${ }^{25}$ Samüt Karabulut v. Turkey (2009).

${ }^{26}$ Alekseyev v. Russia (2010).

${ }^{27}$ Hyde Park v. Moldova (2009); Patyi v. Hungary (2012); Yilmaz Yildiz and Oth. v Turkey (2014).

${ }^{28}$ The United Macedonian Organisation Ilinden and Ivanov v. Bulgaria (2005).

${ }^{29}$ Cissé v. France (2002).
} 
However, in connection with interferences with the right of assembly, it must be emphasised that the finding of the existence of an interference does not automatically mean that Article 11 of the Convention has been violated. It depends on whether this interference passes a review algorithm, which is the same for both interference with freedom of expression and interference with the right of assembly. This review algorithm can be divided into five steps, which can be expressed in the form of questions: 1) Does the present case fall under Article 11 of the Convention?; 2) Was it an interference with the right of the assembly of the complainant?; 3) Was this intervention in accordance with the national law ? $^{30}$; 4) Does the intervention pursue at least one of the legitimate objectives set out in Article 11 (2) of the Convention?; and finally 5) Was this intervention necessary in a democratic society? ${ }^{31}$ In some of its decisions, the ECHR takes a test consisting only of questions 3 ) to 5$)^{32}$.

It should be noted here that the possibilities of interfering with the right of assembly are slightly wider than in the case of the possibilities of interfering with freedom of expression or freedom of thought guaranteed in Articles 8 and 9 of the Convention. In addition, Article 11 (2) of the Convention allows for the imposition of legal restrictions on members of the armed forces, the police, and the administration. In practice, this means that the right to demonstrate may be restricted by law to a significant part of the population linked to the service of the state.

States have an obligation not only to allow the exercise of the right of assembly and, in certain cases, to set the conditions for its holding, or even to ban it, but they are also obliged to actively ensure the realization of the assembly so that it can take place despite possible counterdemonstrations ${ }^{33}$. What all the state authorities (i.e. especially the police) must ensure so that the positive obligation of the state to ensure the implementation and protection of the assembly is fulfilled cannot be clearly find from the case law. In general, states enjoy a wide margin of discretion as to what specific steps to take, and it is important that they are effective and proportionate.

In 1988, the $\mathrm{ECHR}^{34}$ stated that demonstrations must not be attacked by persons who contradict the ideas and claims to be presented. Participants must be able to attend meetings without fear of physical violence; such a fear could discourage associations or other groups promoting common ideas or interests from openly expressing their views on highly controversial issues that affect society. In a democracy, the right to counterdemonstration cannot be extended to block the exercise of the right to demonstrate. True real freedom of peaceful assembly cannot be reduced to a mere obligation of the state not to intervene.

\footnotetext{
${ }^{30} \mathrm{ECHR}$ also calls for a certain quality of this law, as it must be accessible to the person concerned and must be foreseeable as to its effects.

${ }^{31}$ What is assessed are on the one hand public interests protected by Article 11 (2) of the Convention and, on the other hand, the requirements for the free expression of opinion by persons gathered on the streets or in public places, e.g. Skiba v. Poland (2009) and Fáber v. Hungary (2012).

${ }^{32}$ E.g. Primov and oth. v. Russia (2014); DISK and KESK v. Turkey (2012).

${ }^{33}$ Öllinger v. Austria (2006).

${ }^{34}$ Plattform „Ärzte für das Leben“ v. Austria (1988).
} 
Another principle applied in addressing the adequacy of interventions in the right of assembly is the principle of subsidiarity of interventions, although it is not explicitly called like that by the ECHR. This means that a more intensive intervention cannot be used if a less intensive intervention would be sufficient to fulfil the objective. For example, if the assembly is to take place in a park that does not have sufficient capacity for the reported number of demonstrators, this is not a reason to ban the assembly but rather to set a condition to limit the number of demonstrators ${ }^{35}$.

Part of the implementation of the right of assembly may be the restriction of the normal way of life or transport ${ }^{36}$ as a side effect of the assembly, this is not by itself a reason to prohibit the assembly. However, for example, blocking traffic or other activities must not be the aim of the assembly in order to put pressure on the responsible authorities ${ }^{37}$.

Another question is how the state authorities should behave in the event of an unannounced assembly, either for failure to comply with the obligation of the convener or because it is an assembly created spontaneously without the convener (e.g. the participants of the assembly meet in front of the government building at the time of the hearing of the essential issues without anyone inviting them to attend the meeting).

Regarding unannounced peaceful assemblies a distinction must be made between spontaneous assemblies and non-spontaneous assemblies. Spontaneous assemblies enjoy essentially the same protection as permitted assemblies. Conversely, unannounced assemblies that cannot be considered spontaneous enjoy less protection; according to the case law of the ECHR, such assemblies may be dissolved under certain circumstances ${ }^{38}$. However, this interference with the right of assembly must take into account the number of persons and the nature of the place of assembly and, if possible, leave at least a small amount of time for the demonstrators to express their views in undisturbed way ${ }^{39}$. Thus, spontaneous, or non-spontaneous unannounced (and peaceful) assemblies cannot be automatically dissolved simply because they have not been announced in advance. If a national authority does so, there is a risk that such interference will be found by the ECHR to be a disproportionate interference with the freedom of peaceful assembly.

\section{Conclusion}

Although the case law on the right of assembly is not as developed as the case law on freedom of expression, given the decades-long work of the ECHR and the Commission before, this case law also provides sufficient guidance in the application of Article 11 of the Convention. The nature of interference with

\footnotetext{
${ }^{35}$ Cf. Primov and Oth. v. Russia (2014); Barankevich v. Russia (2007).

${ }^{36}$ Körtvélyessy v. Hungary (2016); United Civil Aviation Trade Union and Csorba v. Hungary (2018).

${ }^{37}$ Kudrevičius and Oth.v. Lithuania (2015); Galstyan v. Armenia (2007); Primov and Oth. v. Russia (2014).

${ }^{38}$ Bukta and Oth. v. Hungary (2007); Éva Molnár v. Hungary (2008).

${ }^{39}$ Samüt Karabulut v. Turkey (2009).
} 
the right of assembly is usually repeated as is clear from the case-law from recent years. In the ECHR's decisions on the right of assembly can therefore be traced clear lines of thought of the interpretation and application of this right. The ECHR itself seeks inspiration for the principles applied in cases of freedom of expression in solving problems related to the right of assembly. For this reason, it is useful to know these principles relating to freedom of expression, as they provide guidance on new issues in addition to the issues already resolved.

It is not surprising and it is a long-term trend evident from the ECHR case law that Member States that are generally prone to authoritarian regimes and lower standards of human rights protection come before the ECHR with the most serious violations of assembly law, including criminal sanctions for organizing assemblies or violent repression of demonstrations. However, new problems which show the development of society are also emerging. An example is the problem of the conflict between the right of ownership and the right of assembly, as it is no longer possible to say that the right of ownership took precedence and it was not possible to hold an assembly on his property without the consent of the owner. The conditions under which this is and is not possible are not yet fully clarified and will be the subject of further cases held before the ECHR and the courts of the Contracting States.

\section{References}

The Convention - the European Convention on Human Rights (The Convention for the Protection of Human Rights and Fundamental Freedoms), came into force in 1953.

\section{Cases}

\section{European Court of Human Rights}

Akgöl and Göl v. Turkey, dated 17.5.2011, App. nos. 28495/06 and 28516/06 Alexeyev v. Russia, dated 21.10.2010, App. nos. 4916/07, 25924/08,14599/09 Appleby v. UK, dated 6. 5. 2003, App. no. 44306/98

Bączkowski and Others v. Poland, dated 3.05.2007, App. no. 1543/06

Barankevich v. Russia, dated 26.07.2007, App. no. 10519/03

Barraco v. France, dated 5. 3. 2009, App. no. 31684/05

Bukta and Others v. Hungary, dated 17.07.2007, App. no. 25691/04

Cissé v. France, dated 9.04.2002, App. no. 51346/99

DISK and KESK v. Turkey, dated 27.11.2012, App. no. 38676/08

Djavit An v. Turkey, dated 20.02.2003, App. no. 20652/92

Éva Molnár v. Hungary, dated 7.10.2008, App. no. 10346/05

Ezelin v. France, dated 26.04.1991, App. no. 11800/85

Fáber v. Hungary, dated 24.07.2012, App. no. 40721/08

Feldek v. Slovakia, dated 12.07.2001, App. no. 29032/95

Galstyan v. Armenia, dated 15.11.2007, App. no. 26986/03

Galstyan v. Armenia, dated 15. 11. 2007, App. no. 26986/03

Gypsy Council v. UK dated 14.05.2002, App. no. 66336/01 
Hyde Park v. Moldova, dated 7.04.2009, App. no. 18491/07

Kakabadze and Others v. Georgia, dated 2.10.2012, App. no. 1484/07

Körtvélyessy v. Hungary, dated 5.04.2016, App. no. 7871/10

Kudrevičius and Others v. Lithuania, dated 15.10.2015, App. no. 37553/05

Öllinger v. Austria, dated 29.06.2006, App. no. 76900/01

Oya Ataman v. Turkey, dated 5.12.2006, App. no. 74552/01

Refah Partisi and Others v. Turkey, dated 13.02.2003, App. no. 41340/98

Patyi v. Hungary, dated 17.01.2012, App. no. 35127/08

Plattform „Ärzte für das Leben“ v. Austria, dated 21.6.1988, App. no. 10126/82

Primov and Others v. Russia, dated 12.06.2014, App. no. 17391/06

Samüt Karabulut v. Turkey, dated 27.01.2009, App. no. 16999/04

Sergey Kuznetsov v. Russia, dated 23.10.2008, App. no. 10877/04

Skiba v. Poland, dated 7.07.2009, App. no. 10659/03

Stankov and the United Macedonian Organisation Ilinden v. Bulgaria, dated 2.10.2001, App. nos. 29221/95 and 29225/95

Štefanec v. Czech Republic, dated 18.07.2006, App. no. 75615/01

Tsonev v. Bulgaria, dated 13.04.2006, App. no. $45063 / 99$

United Civil Aviation Trade Union and Csorba v. Hungary, dated 22.5.2018, App. no. $27585 / 13$

United Macedonian Organisation Ilinden and Ivanov v. Bulgaria, dated 20.10.2005, App. no. $44079 / 98$

Vona v. Hungary, dated 9.07.2013, App. no. 35943/10

Yilmaz and Kiliç v. Turkey, dated 17.07.2008, App. no. 68514/01

\section{European Commission of Human Rights}

Christians against Racism and Fascism v. UK, dated 16.7.1980, App. no. 8440/78

Rassemblement Jurassien Unité Jurassienne v. Switzerland, dated 10.10.1979, App. no. $8191 / 78$ 


\title{
"Fake News" Legislation in Thailand: The Good, the Bad and the Ugly ${ }^{1}$
}

\author{
By Robert Smith ${ }^{*} \&$ Mark Perry ${ }^{ \pm}$
}

Thailand, as with some of its ASEAN partners, is using cybercrime legislation to prosecute those spreading "fake news". Thailand took legislative action by amending the 2007 Computer Crime Act in 2017. The new Act makes it an offence to use a computer system in a way likely to "cause damage to the maintenance of national security, public safety, national economic security, or infrastructure for the common good of the Nation, or to cause panic amongst the public". The amended legislation also created a computer data screening panel, which monitors the internet for "fake news". Probably a greater threat to personal freedom is individuals and organisations that surf the internet looking for posts that conflict with their point of view and then take legal action so that the supposed perpetrators are prosecuted and probably persecuted as well. Truth is not necessarily a defence. The lèse-majesté legislation, as set out in the Constitution and the Criminal Code, makes it an offence to criticise the Crown. This is supported by the anti-defamation law which allows for civil and criminal remedies. This paper dissects the legislation and shows how it can be misused to persecute those critical of the government or private enterprises. ${ }^{l}$

Keywords: Fake news; Computer crimes; Victimisation; lèse-majesté; Defamation.

\section{Introduction}

Whilst most will associate fake news with President of the United States Donald Trump, ${ }^{2}$ in fact it can be traced back to antiquity. The Greek storyteller, Aesop (ca. 620 and $560 \mathrm{BCE})^{3}$ told the tale of "The Boy who Cried Wolf". Briefly, the boy in the fable was tending sheep and on two occasions ran into his village crying out "Wolf! Wolf !" On each occasion the villagers ran to his assistance only to find out it was a hoax. On the third occasion there was in reality a wolf, but the villagers decided they would not be fooled again so did not come to help and many of the sheep were killed.

\footnotetext{
* PhD, Academic Advisor, Walailak University,Thaiburi, Tha Sala District. Nakhon Si Thammarat Thailand. Corresponding author. E-mail: r.b.smith@unswalumni.com.

${ }^{ \pm}$Professor, Chair of the Academic Board of School of Law, University of New England, Armidale, NSW, Australia. E-mail: mark.perry@une.edu.au.

${ }^{1}$ This research is supported by an Australian Government Research Training Program (RTP) Scholarship.

${ }^{2}$ E.g. Farhall et al (2019) at 4354.

${ }^{3}$ Aesop's Fables Interactive Book (adapted from the book "The Aesop for Children: with Pictures by Milo Winter", published by Rand, McNally \& Co in 1919). (Library of Congress). Introduction.

${ }^{4}$ Aesop, 'The Shepherd Boy \& the Wolf.
} 
These two examples show two different types of fake news. In the case of the President of the United States it appears that any comment which does not put him in a favourable light, or simply disagrees with, especially in the media, is fake news. In the case of the boy who cried wolf, the news was untrue and it was used to elicit a response from the receivers of the message on each occasion. Unfortunately, the third time he asked for help the news was true but because of the boy's previous behaviour was considered by the recipients to be fake. These concepts will be discussed later in this paper.

Both types of fake news are the subject of legislation in many of the member countries of the Association of Southeast Asian Nations (ASEAN) $)^{5}$. The focus of this paper is the legislation used in Thailand to prosecute, and often persecute, those considered to be spreading what the authorities, in light of there being no definition in the Thai laws, view as fake news no matter how trivial.

The literature review sets the scene in the context of responses to fake news amongst the ASEAN member states.

As will be seen, Thailand has three legal instruments available to prosecute those suspected of spreading fake news: Computer Crime Act (as amended). ${ }^{6}$ lèsemajesté, as defined in the Constitution ${ }^{7}$ and the Criminal Code, ${ }^{8}$ and finally defamation, also defined in the Criminal $\operatorname{Code}^{9}$ to prosecute what is perceived as fake news.

Finally, the paper will discuss the application of the law including examples of good, bad and ugly uses of law with particular emphasis on the Thai response to fake news associated with the spread of the COVID-19 virus in Thailand. Such an analysis is important as this will indicate whether or not the laws are being prosecuted in an overzealous manner as has been claimed by some commentators. ${ }^{10}$

\section{Literature Review}

Haciyakupoglu et al reported that fake news in the digital age covers a wide spectrum with overlapping motivations that can be political, subversive, financial, and entertainment. ${ }^{11}$ Its impact is amplified through several mechanisms: low cost internet platforms; social media, where participants interact as they consume, produce and circulate content; and artificial intelligence, which can automate the whole process. They also noted that even the use of the term fake news "is also used by parties to denigrate content or points of view that are at odds with their own beliefs". "It becomes a social security issue when it undermines the

\footnotetext{
${ }^{5}$ The members of ASEAN are Brunei Darussalam, Cambodia. Indonesia, LaoPDR, Malaysia, Myanmar, Philippines, Singapore, Thailand and Vietnam.

${ }^{6}$ Computer Crime Act (No 2) B.E. 2560 (2017).

${ }^{7}$ Constitution of the Kingdom of Thailand (B.E. 2560 (2017)).

${ }^{8}$ The Criminal Code updated to 2009.

${ }^{9}$ Ibid.

${ }^{10}$ E.g. Hunt (2020).

${ }^{11}$ Haciyakupoglu et al. (2018) at 3.

${ }^{12}$ Ibid.
} 
foundations of the nation state, e.g. social cohesion, public institutions, peace and order. They identified a number of issues in legislating against fake news, namely: issues with the definition of fake news; the extraterritorial reach of cyberspace; challenges in identifying the perpetrator; and the sophistication of disinformation campaigns. ${ }^{13}$ Naturally, content related regulations would also face many challenges in cyberspace. ${ }^{14}$

The Asia Centre, based in Bangkok, has criticised the generally vague definition of fake news particularly in the countries of Southeast Asia. ${ }^{15}$ It sees three main consequences of such imprecise definitions: they allow for complaints to be easily filed by any opponents; they give government agencies a mechanism to file complaints, thus potentially making criticisms or voicing opinions against public office holders or public institutions a criminal offence; also, the laws may criminalise the service providers. The Centre noted that:

"In Southeast Asia, government officials tend to shield themselves and their institutions from criticisms by framing censures for their actions as fake news. Add to this governments' efforts to eradicate 'fake news' through vague laws, it then further dilutes the already worn out trust." 16

In January 2018 the European Commission appointed a high-level group of experts (HLEG) to advise it on countering the spread disinformation online. ${ }^{17}$ The Committee preferred the word "disinformation" over "fake news" and "includes all forms of false, inaccurate, or misleading information designed, presented and promoted to intentionally cause public harm or for profit". ${ }^{18}$ Rather than recommending a legislative response they recommended responses based on five pillars: enhance transparency of online news; promote media and information literacy; develop tools for empowering users and journalists; safeguard the diversity and sustainability of the European news media ecosystem; and, promote continued research on the impact of disinformation. ${ }^{19}$

On 10 May 2018 the Ministers Responsible for Information of the ASEAN Member States adopted a framework to minimise the harmful effects of fake news. ${ }^{20}$ The framework included the following elements: ${ }^{21}$

a) Cooperation in the fields of information and media, and support development of socially responsible media in ASEAN;

b) Capitalise on the potential of online and social media and ensure that the internet remains a safe space;

c) Raise awareness on the potential problems posed by fake news;

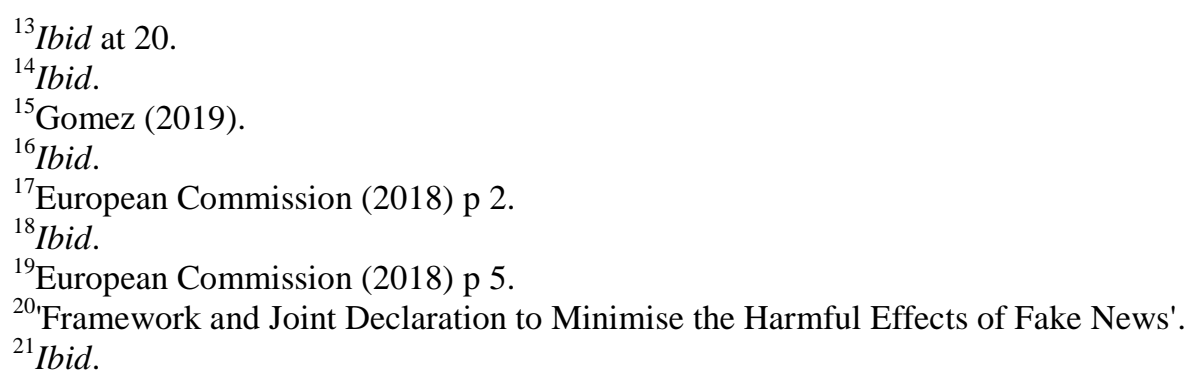


d) Improve digital literacy;

e) Strengthen national capacity to detect and respond to fake news;

f) Encourage stakeholders to build on industry norms and guidelines against fake news;

g) Share best practices and experiences on responses to the challenge of fake news; and

h) Encourage all ASEAN partners and relevant stakeholders to cooperate and join hands in the implementation of this Framework.

The framework did not, however, define fake news.

It is claimed that fake news has been a key political weapon in Thailand particularly since the 2014 military coup. ${ }^{22}$ The best funded anti-false information group is the Cyber Scouts founded in 2010 and funded under the Ministry of Digital Economy and Society and offering training workshops for high school and university students across Thailand. As of 2016 more than 120,000 students had been recruited. "In addition to monitoring, well-intended citizens and vigilante groups take part in 'cyber trolling' of critical media, activists, and dissidents". Sombatpoonsiri also claims that the then "junta's classification of truthfulness and falsehood has enabled it to claim to be the sole arbiter of truth, while those who challenge their edicts are said to spread 'lies'." 24 Hunt points out that Thailand's emergency proclamation under COVID-19 will enable the government to censor and even shut down the media. ${ }^{25}$

\section{Methodology}

This research is based on the documentary research concept as it provides an analysis of the Thai Constitution, Criminal Code and legislation as it applies to the prosecution of persons spreading fake news. The authors were faced with two major difficulties when preparing this paper, as follows.

Firstly, It must be borne in mind at the outset that there are complications when translating laws from one language to another as many of our language constructs are tied to our culture and understanding. This means that the translation may be imperfect. ${ }^{26}$ This commentary is based on the "unofficial" English version of legislation. The version of Thai Constitution ${ }^{27}$ as used in this paper is that issued by the Thai Government, whilst that of the Thai Criminal Code ${ }^{28}$ was translated and published by a private law firm. Similarly, the version the Computer Crime $\mathrm{Act}^{29}$ was obtained from Wikisource. All English translations are "unofficial", of, course, as they are not in Thai.

\footnotetext{
${ }^{22}$ Sombatpoonsiri (2019).

${ }^{23}$ Ibid.

${ }^{24}$ Ibid.

${ }^{25}$ Hunt (2020).

${ }^{26}$ Smith (2019).

${ }^{27}$ Thai Constitution.

${ }^{28}$ The Criminal Code.

${ }^{29}$ Computer Crime Act (No. 2).
} 
Secondly, in Thailand "[Court] decisions are often brief and there is no guarantee they will be publicly available. Courts maintain basic records of previous cases on file at the courthouse". The authors have had to rely on English language secondary sources such as news services and newspapers and their reporting of government press conferences, police press conferences and court decisions.

As reporting of the arrest and prosecution of purveyors of fake news is an almost daily occurrence in Thailand there is an extensive amount of available material.

\section{Thai Legislation}

\section{Introduction}

"Fake news" is not defined in any Thai legislation. The legislation used to prosecute distributors of "fake news" is the Computer Crime Act (as amended). ${ }^{31}$ As will be seen, authorities also use lèse-majesté and defamation to prosecute what is perceived as "fake news".

\section{Computer Crime Act}

Thailand first enacted a Computer Crime Act in 2007. ${ }^{32}$ This was subsequently amended by the Computer Crime Act (No 2) in $2017 .^{33}$ The analysis which follows is based on the consolidated Act.

"Fake News" is covered by Section 14. The original $\mathrm{Act}^{34}$ specified the following computer related offences that could be:

a) inputting forged computer data "in whole or in part or false computer data in a manner likely to cause injury to another person or the public"; ; 35

b) inputting false computer data "in a manner likely to cause injury security or public panic"; 36 and

c) publish and forward computer data with the knowledge of the offence. ${ }^{37}$

Section 14 was completely replaced in the amendments of the Computer Crime Act (No 2) (38 $^{38}$ and the amendments are included verbatim as follows:

\footnotetext{
${ }^{30}$ Indananda, Taweepon \& Wheatley (2017).

${ }^{31}$ Computer Crime Act (No. 2).

${ }^{32}$ Computer Crime Act.

${ }^{33}$ Computer Crime Act (No. 2).

${ }^{34}$ Computer Crime Act.

${ }^{35}$ Ibid s 14(1).

${ }^{36}$ Ibid s 14(2).

${ }^{37}$ Ibid s 14(5).

${ }^{38}$ Computer Crime Act (No. 2).
} 
1. Any person who commits any of the following crimes shall be liable to imprisonment for not more than five years, or a fine of not exceeding one hundred thousand baht, or both:

(1) dishonestly or deceitfully bringing into a computer system computer data which is distorted or forged, either in whole or in part, or computer data which is false, in such a manner likely to cause injury to the public but not constituting a crime of defamation under the Penal Code;

(2) bringing into a computer system computer data which is false, in such a manner likely to cause damage to the maintenance of national security, public safety, national economic security, or infrastructure for the common good of the Nation, or to cause panic amongst the public;

(3) $[\ldots \ldots .$.

(4) $[\ldots \ldots$.

(5) publishing or forwarding computer data, with the knowledge that it is the computer data under (1), (2), (3), or (4).

2. If the crime under paragraph 1 (1) is not committed against the public but it is committed against any particular person, the criminal or the person who publishes or forwards the computer data as said shall be liable to imprisonment for not more than three years, or a fine of not exceeding sixty thousand baht, or both, and the crime shall be compoundable.

Section 20 mandates that the Minister appoint one or more computer screening panels. ${ }^{39}$ Each panel consists of nine members, three of whom are from the field of human rights, mass communication, information technology or other relevant fields. ${ }^{40}$ If computer data are circulating contrary "to peace and order or good morals" the Minister may, with the approval of a computer screening panel, authorise legal action to terminate circulation of the data or delete the data from computer systems. ${ }^{41}$ Court activities ${ }^{42}$ are undertaken in accordance with the Criminal Procedures Code. ${ }^{43}$

The amended law was followed by five regulations which unfortunately are unavailable in English. Only one of the regulations is relevant, namely: Ministerial Notification on the Appointment of the Computer Data Screening Panel under the Computer Crime Act. ${ }^{44}$

"For determining if a computer data is contrary to the public order and good morals of the Thai people or not, the Computer Data Screening [Panel] must take into account precedent established by prior Supreme Court judgments and the Thai social context. ",45

\footnotetext{
${ }^{39}$ Computer Crime Act (No. 2) s 20(3).

${ }^{40}$ Ibid.

${ }^{41}$ Ibid s 20(2).

${ }^{42}$ Ibid s 20(4).

${ }^{43}$ The Criminal Procedure Code (tr Yongyuth V's Yuthankun) (update 2009) (Thailand).

${ }^{44}$ Somwaiya (2017).

${ }^{45}$ Ibid.
} 
Lèse-Majesté

Section 6 of the Thai Constitution states that "[T]he King shall be enthroned in a position of revered worship and shall not be violated. No person shall expose the King to any sort of accusation or action". 46

The coverage is further extended in the Criminal Code ${ }^{47}$ "Whoever defames, insults or threatens the King, the Queen, the Heir-apparent or the Regent, shall be punished with imprisonment of three to fifteen years". 48

\section{Defamation}

To fully understand the implications of the Thai deformation law it is necessary to quote verbatim s 326 of the Thai Criminal Code.

"Whoever, imputes anything to the other person before a third person in a manner likely to impair the reputation of such other person or to expose such other person to be hated or scorned, is said to commit deformation and shall be punished with imprisonment not exceeding one year or fined not exceeding twenty thousand Baht, or both. ${ }^{, 49}$

A person is not guilty of defamation if they act in good faith and expresses an opinion or statement: of self-justification or for protection of a legitimate interest $^{50}$ or is an official exercising their official function; ${ }^{51}$ or gives fair comment on any person or thing being publicly criticised; ${ }^{52}$ or provides a fair report of any open court proceedings or meeting. ${ }^{53}$ Truth is a defines except if "such imputation [that led to the defamation action] concerns personal matters, and such proof is not be of benefit to the public." 54

\section{Accusations of Promotion of Fake News by the Military}

During a no-confidence debate in the Thai parliament in February an opposition member of parliament claimed that the army was behind cyber-attacks on critics by spreading fake news and damaging materials. ${ }^{55}$ During the debate "he read from what he said were two leaked military memos that ordered army personnel to create fake social media accounts to 'offer counter narrative, for

\footnotetext{
${ }^{46}$ Thai Constitution art 6.

${ }^{47}$ The Criminal Code updated to 2009 (tr Y. V. Yuthankun).

${ }^{48}$ Ibid s 112.

${ }^{49}$ The Criminal Code s 326.

${ }^{50}$ Ibid s 329(1).

${ }^{51}$ Ibid s 329(2).

${ }^{52}$ Ibid s 329(3).

${ }^{53}$ Ibid s 329(4).

${ }^{54}$ Ibid s 330.

${ }^{55}$ 'Opposition alleges army behind cyber attacks on critics, holds PM responsible' (2020).
} 
criticism of the government". ${ }^{56}$ This was denied by the Prime Minister and the military. ${ }^{57}$ The incriminating documents appeared on Facebook soon after. ${ }^{58}$

\section{Prosecutions for Posting Fake News in Thailand}

\section{Lèse-Majesté and Fake News}

Dr Puangthorn Pawakapan from Chulalongkorn University noted that Thai authorities "tend to drop the lèse-majesté charge and use the Computer Crime Act only in order not to draw attention to the monarchy" ${ }^{59} \mathrm{He}$ claimed that the network was targeting the websites and social media platforms and of the rights activists in the violence-hit provinces in the far south of Thailand. He further claimed that it was part of an information operation waged by the Internal Security Operation Command (ISOC). ${ }^{60}$

A notorious case is that of Ampon Tangnoppakul ("Uncle SMS") who was imprisoned for 20 years for a crime he apparently did not commit. ${ }^{61} \mathrm{He}$ was accused of sending three SMS messages critical of the king. He claimed that he did not know how to make or send an SMS as he was barely competent with a mobile phone. He further claimed that he did not know the recipient of the messages nor his mobile number. His denials apparently could not be proven and were deemed irrelevant. ${ }^{62}$

In a University Seminar in 2014 a Thai academic questioned whether an elephant battle actually occurred between King Naresuan the Great and a Burmese prince in the early $17^{\text {th }}$ Century. ${ }^{63}$ He was charged with lèse-majesté but had the charges dropped in January 2018 due, he said, to the intervention of the king. ${ }^{64}$ The Court said that it was due to lack of evidence. ${ }^{65}$

A selection of cases from 2018 is provided in Table $\mathbf{1}$ to show the variety of cases for which details are known.

\footnotetext{
${ }^{56}$ Thai PM (2020).

${ }^{57}$ Ibid.

${ }^{58}$ 'IO Documents No Longer Secret (2020).

${ }^{59}$ Cited in Quinley (2019).

${ }^{60}$ 'Opposition alleges army behind cyber attacks on critics (2020)..

${ }^{61}$ Hunt (2012).

${ }^{62}$ Ibid.

${ }^{63}$ Wongcha-um (2018).

${ }^{64}$ Ibid.

${ }^{65}$ Ibid.
} 
Table 1. Some Reported Lèse-Majesté Cases under Section 112 of the Thai Criminal Code from 2018 onwards

\begin{tabular}{|c|c|c|}
\hline Case $^{66}$ & Brief Description $^{67}$ & Reported Action $^{68}$ \\
\hline $\begin{array}{l}\text { Thanat aka } \\
\text { "Tom Dundee" }\end{array}$ & $\begin{array}{l}\text { Public speech in } 2011 \text { to } \\
\text { which the defendant pleaded } \\
\text { guilty }\end{array}$ & $\begin{array}{l}\text { On } 29 \text { March } 2018 \text { he was not } \\
\text { convicted as it was not clear to the } \\
\text { court that plaintiff had committed the } \\
\text { alleged acts of royal defamation }\end{array}$ \\
\hline $\begin{array}{l}\text { Thanat aka } \\
\text { "Tom Dundee" }\end{array}$ & $\begin{array}{l}\text { Public speech in } 2011 \text { to } \\
\text { which the defendant pleaded } \\
\text { guilty }\end{array}$ & $\begin{array}{l}\text { On } 29 \text { June } 2018 \text { he was not convicted } \\
\text { as it was not clear to the court that } \\
\text { plaintiff had committed the alleged } \\
\text { acts of defamation, insult or threat. }\end{array}$ \\
\hline $\begin{array}{c}\text { Sakan (last name } \\
\text { withheld) }\end{array}$ & $\begin{array}{l}\text { Talk given whilst in Bangkok } \\
\text { Remand Prison to which the } \\
\text { prisoner pleaded guilty. }\end{array}$ & $\begin{array}{l}\text { On } 14 \text { November } 2018 \text { he was not } \\
\text { convicted as it was not possible for the } \\
\text { court to ascertain that the alleged } \\
\text { statement was defamatory to the King } \\
\text { or Queen. }\end{array}$ \\
\hline $\begin{array}{l}\text { Human rights } \\
\text { lawyer Prawet } \\
\text { Prapanukul }\end{array}$ & $\begin{array}{l}\text { Indicted with posting ten } \\
\text { Facebook messages deemed } \\
\text { in violation of } \mathrm{s} 112 \text { and } \\
\text { another three deemed in } \\
\text { violation of s } 116 \text { (Sedition). }\end{array}$ & $\begin{array}{l}\text { On } 27 \text { June } 2018 \text { he was sentenced for } \\
\text { the three counts under s 116. "The } \\
\text { Court, however, mentioned nothing } \\
\text { about the lèse majesté charges against } \\
\text { him, and the ten incriminating } \\
\text { messages." }\end{array}$ \\
\hline $\begin{array}{l}\text { A visually } \\
\text { impaired woman } \\
\text { (Ms. Nurahayadi } \\
\text { Masao) }\end{array}$ & $\begin{array}{l}\text { Used an application for the } \\
\text { visually impaired to post a } \\
\text { comment and share an article } \\
\text { on her personal Facebook } \\
\text { page in the wake of the } \\
\text { passing of King Rama IX. }\end{array}$ & $\begin{array}{l}\text { On } 4 \text { January } 2018 \text { she was convicted } \\
\text { and sentenced to } 18 \text { months } \\
\text { imprisonment. She was mysteriously } \\
\text { discharged from prison on } 23 \text { January } \\
\text { - no one knew who paid for her } \\
\text { discharge or how much. } \\
\text { On appeal on } 12 \text { February } 2018 \text { the } \\
\text { court dismissed the case on the basis } \\
\text { that as the defendant had a visual } \\
\text { impairment in both eyes it was not } \\
\text { possible that she could copy and paste } \\
\text { the article whilst knowing that the } \\
\text { article was deemed offensive to the } \\
\text { late king. } \\
\text { On } 5 \text { March } 2018 \text { she was arrested } \\
\text { and on } 6 \text { March } 2018 \text { was found } \\
\text { guilty of violating the Computer } \\
\text { Crime Act in October } 2016 \text { for } \\
\text { sharing an audio clip of a radio } \\
\text { program }\end{array}$ \\
\hline
\end{tabular}

\footnotetext{
${ }^{66}$ Given by the authors to distinguish cases.

${ }^{67}$ Details are usually quite sketchy as it is an offence to republish the details of the original offence.

${ }^{68}$ All offences are under s112 of the Thai Criminal Code unless otherwise indicated. As noted in the methodology, information is difficult to obtain and the status is that at the time of the published report in the local media.

${ }^{69}$ TLHR, 'Changes in Thailand's lèse majesté prosecutions in 2018' (2019a).
} 


\begin{tabular}{|c|c|c|}
\hline Case $^{66}$ & Brief Description $^{67}$ & Reported Action $^{68}$ \\
\hline $\begin{array}{c}\text { 'Kay' } \\
\text { (pseudonym) }\end{array}$ & $\begin{array}{l}\text { Posted an advertisement on } \\
\text { Facebook to sell his } \\
\text { collectable coins. He became } \\
\text { involved in a heated } \\
\text { exchange with one Facebook } \\
\text { user who screen-captured the } \\
\text { conversation and } \\
\text { subsequently reported him to } \\
\text { authorities. }\end{array}$ & $\begin{array}{l}\text { On } 5 \text { July } 2018 \text { the Court dismissed } \\
\text { the s112 charges but found him guilty } \\
\text { of spreading false information online } \\
\text { in violation of s14(1) of the Computer } \\
\text { Crime Act. He was sentenced to } 8 \\
\text { months in prison. The latter verdict } \\
\text { was appealed. }\end{array}$ \\
\hline $\begin{array}{l}\text { Royal Arch } \\
\text { Arson Case }\end{array}$ & $\begin{array}{l}11 \text { defendants were accused } \\
\text { of setting fire to decorative } \\
\text { arches to honour the King in } \\
\text { Khon Kaen in early May } \\
\text { 2017. }\end{array}$ & $\begin{array}{l}\text { The charges included that of lèse- } \\
\text { majesté. They all pleaded guilty to all } \\
\text { of the charges and sentenced. Six } \\
\text { appealed and on } 18 \text { September the six } \\
\text { were acquitted of the lèse-majesté } \\
\text { charges as the court found that whilst } \\
\text { they intended to commit an act of } \\
\text { mischief by damaging the decorative } \\
\text { arches, they had no intention to violate } \\
\text { s112. They were sentenced to } \\
\text { imprisonment on the other charges. }\end{array}$ \\
\hline Mr Anant & $\begin{array}{l}\text { It was alleged the defendant } \\
\text { verbally insulted two Thai } \\
\text { princesses in a conversation } \\
\text { with a security guard in } 2012 \text {. } \\
\text { He was charged with lèse- } \\
\text { majesté and criminal } \\
\text { deformation. }\end{array}$ & $\begin{array}{l}\text { He was found guilty of criminal } \\
\text { deformation (s326) but not of lèse- } \\
\text { majesté as the court considered the } \\
\text { princesses were not covered under } \\
\text { s112 as there was only one heir } \\
\text { apparent and that was the Crown } \\
\text { Prince. }\end{array}$ \\
\hline $\begin{array}{l}\text { Chanoknan } \\
\text { Ruamsap aka } \\
\text { "Cartoon" }\end{array}$ & $\begin{array}{l}\text { In January } 2018 \text { the activist } \\
\text { was summonsed to answer a } \\
\text { charge for sharing a BBC } \\
\text { Thai news link regarding the } \\
\text { profile of King Rama X. } \\
\text { According to the Bangkok } \\
\text { Post she also wrote "If you } \\
\text { dare write. I dare share."70 }\end{array}$ & $\begin{array}{l}\text { She fled to South Korea before the } \\
\text { case was heard and was subsequently } \\
\text { granted political refugee status. }\end{array}$ \\
\hline
\end{tabular}

Source: Thai Lawyers for Human Rights ${ }^{72}$

According the Thai Lawyers for Civil Rights those tried for lèse-majesté in military courts following the 2014 coup were subject of "sentencing guidelines" of seven to ten years per posting. ${ }^{73}$ As the sentences are cumulative the terms of imprisonment were extreme with one person being sentenced to 70 years for ten message posts with the prison term automatically educed to 35 years due to his

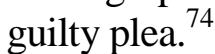

\footnotetext{
${ }^{70}$ Thai activist gets political refugee tag (2018).

${ }^{71}$ Ibid.

${ }^{72}$ TLHR (2019a).

${ }^{73}$ TLHR (2019b).

${ }^{74}$ Ibid.
} 
A complaint, alleging a violation of the Computer Crime Act, was lodged in March 2018 against a Thai magazine for posting images of an art student's drawing of three ancient Thai kings wearing face masks to call attention to the seasonal air pollution in Chiang Mai. ${ }^{75}$ It was claimed that the drawings "negatively affected the image of Thailand's ancient kings". ${ }^{76}$ It took six months for the case to be dropped. ${ }^{77}$ The question could be asked: why were the charges not lèse-majesté?

Apparently, no member of the royal family has ever filed a charge of lèsemajesté! ${ }^{78}$

\section{Defamation Law and Fake News}

In a 2018 editorial the Bangkok Post commented that "the price of telling the truth to the powerful can be high and devastating for ordinary people in Thailand, where the criminal defamation law is more popular than the civil libel law". ${ }^{79}$ The powerful use this process because they know that prospect of jail is more of a threat than paying financial redress. ${ }^{80}$ It further argues that police and public persecutors give little consideration to whether the damage caused is significant enough to be considered criminal. ${ }^{81}$ They cited two recent Thai cases where, as in the case of deformation proceedings the only test was whether or not the act of speaking out count hurt the reputation of the plaintiffs.

It should be noted that Thai law allows the plaintiff to use the resources of the police and state prosecutors to pursue defamation cases in court. ${ }^{82}$ Article 19 claims that this is tantamount to using the resources of the State to redeem a personal interest. ${ }^{83}$

A human right defender, Andy Hall, has been found guilty in a number of criminal and civil prosecutions. ${ }^{84} \mathrm{He}$ was involved in at least three cases of investigations into labour disputes. In one case he was sentenced to prison, in the second he was ordered to pay damages. The third case he was involved with is reported below. By this time, he considered he was the subject of unbearable judicial harassment and left the country before the case was heard. ${ }^{85}$

In 2016 a group of migrant workers from Myanmar complained to the National Human Rights of Thailand about their poor conditions at a poultry farm. ${ }^{86}$ The owner sued the workers for defamation and lost. This was followed by the upholding of the award of compensation to the workers in January 2019.

\footnotetext{
${ }_{76}^{75}$ United States Department of State (2018) p 18.

${ }^{76} \mathrm{Ibid}$.

${ }^{77}$ Ibid.

${ }^{78}$ Hunt (2012).

${ }^{79}$ 'Weaponised defamation' (2018).

${ }^{80}$ Ibid.

${ }^{81}$ Ibid.

${ }^{82}$ Article 19 and The National Press Council of Thailand, 2009) para 6.1.1.

${ }^{83} \mathrm{Ibid}$.

${ }^{84}$ Office of the High Commissioner for Human Rights.

${ }^{85}$ Ibid.

${ }^{86}$ Editorial Board (2020).
} 
Unfortunately for her, a Thai journalist in 2016 tweeted on the complaint and used the words "Slave Labour". She was charged with defamation and on 24 December 2019 she was found guilty of defamation and sentenced to two years imprisonment. As per news reports the court found "she had not weighed the potential reputational damage to the farm, had not checked on the accuracy of the tweet and therefore had acted in bad faith". The case was under appeal and the journalist on bail at the time of writing. ${ }^{87}$

The decision of the Supreme Court in the case of Mr Anant mentioned in Table 1 raised some unusual legal arguments. In this case the defendant was found guilty of criminal deformation even though the injured parties had not lodged a complaint. ${ }^{88}$ The Thai Lawyers for Human Rights argue that this is contrary to the normal course of law as without a complaint an investigation cannot commence. ${ }^{89}$ If an investigation were undertaken without a complaint the public prosecutor could not take up the case as the prior investigation would be considered to be invalid. They also note that the Court invoked the 2017 Constitution to justify the investigation even though the offence was committed prior to the promulgation of the Constitution. ${ }^{90}$ Finally, they concluded that "the Court invoked law retrospectively to convict the defendant."

\section{Computer Crimes and Fake News}

\section{1) General Offences}

A selection of cases reported in Thailand's English language press is provided in Table 2.

Table 2. Miscellaneous Cases

\begin{tabular}{|l|l|l|}
\hline Case & \multicolumn{1}{|c|}{ Brief Description } & \multicolumn{1}{c|}{ Reported Action"2 } \\
\hline $\begin{array}{l}\text { 'Abandoned Phuket } \\
\text { Zoo' post }\end{array}$ & $\begin{array}{l}\text { A video was posted on Facebook } \\
\text { claiming that Phuket Zoo had } \\
\text { abandoned its animals and } \\
\text { requested donations to the } \\
\text { posters account. }\end{array}$ & $\begin{array}{l}\text { Four persons "charged with } \\
\text { entering false information to a } \\
\text { computer system which } \\
\text { negatively affected others". }\end{array}$ \\
\hline Viral sex toy video95 & $\begin{array}{l}\text { A video was posted on Facebook } \\
\text { showing a woman playing with a } \\
\text { sex toy in public (it amassed } \\
\text { over7 million views). }\end{array}$ & $\begin{array}{l}\text { Police investigating and when } \\
\text { suspects are apprehended, they } \\
\text { will be charged with creating } \\
\text { and distributing pornographic } \\
\text { or indecent material online. } \\
\text { Those who share the video }\end{array}$ \\
\hline
\end{tabular}

\footnotetext{
${ }^{87} \mathrm{Ibid}$.

${ }^{88}$ TLHR (2018a).

${ }^{89} \mathrm{Ibid}$.

${ }^{90}$ Ibid.

${ }^{91}$ Ibid.

${ }^{92}$ As noted in the methodology information is difficult to obtain and the status is that at the time of the published report in the local media.

${ }^{93}$ Thongtub (2020a).

${ }^{94}$ Ibid.

${ }^{95}$ 'Thai police hunt couple behind viral sex toy video (2020).
} 


\begin{tabular}{|c|c|c|}
\hline Case & Brief Description & Reported Action $^{92}$ \\
\hline & & could also face prosecution. \\
\hline $\begin{array}{l}\text { The former soldier } \\
\text { under the influence } \\
\text { of alcohol }\end{array}$ & $\begin{array}{l}\text { The accused posted of Facebook } \\
\text { that he intended to commit a } \\
\text { mass shooting in a Department } \\
\text { store. }\end{array}$ & $\begin{array}{l}\text { Faced charges under the } \\
\text { Computer Crime Act and } \\
\text { wearing an army uniform } \\
\text { without permission. }{ }^{96}\end{array}$ \\
\hline $\begin{array}{l}\text { House dissolution to } \\
\text { avoid censure } \\
\text { debate }\end{array}$ & $\begin{array}{l}\text { Rumours were spreading that } \\
\text { there would be a dissolution of } \\
\text { the House of Representatives to } \\
\text { avoid a planned censure debate. }\end{array}$ & $\begin{array}{l}\text { Deputy Prime Minister said } \\
\text { such news was fake and "legal } \\
\text { action would be taken against } \\
\text { those who may have circulated } \\
\text { it to scare the people and } \\
\text { adversely affect the } \\
\text { economy". }\end{array}$ \\
\hline $\begin{array}{l}\text { Religion of Prime } \\
\text { Minister's wife }\end{array}$ & $\begin{array}{l}\text { Fake news claimed his wife was } \\
\text { a Muslim when in fact she was a } \\
\text { Buddhist }\end{array}$ & $\begin{array}{l}\text { Prime Minister stated that if } \\
\text { false reports cause damage } \\
\text { legal action will be taken. }{ }^{98}\end{array}$ \\
\hline $\begin{array}{l}\text { Tax on feminine } \\
\text { hygiene products }\end{array}$ & $\begin{array}{l}\text { Opposition party spokeswoman } \\
\text { reposted a story from a web-site } \\
\text { that there would be a tax increase } \\
\text { on such products. She stated that } \\
\text { she posted it in good faith. }\end{array}$ & $\begin{array}{l}\text { Legal action was being } \\
\text { prepared under the Computer } \\
\text { Crime Act. }{ }^{99}\end{array}$ \\
\hline $\begin{array}{l}\text { Distortion of Prime } \\
\text { Minister's motto for } \\
\text { National Children's } \\
\text { Day }\end{array}$ & $\begin{array}{l}\text { The official motto was: "Thai } \\
\text { Children must uphold unity and } \\
\text { be responsible Thai citizens." } \\
\text { An opposition party spokesman } \\
\text { woman used as her motto "Thai } \\
\text { Children must go to the } \\
\text { Skywalk" "presumably in } \\
\text { reference to the recent rally by } \\
\text { her party's supporters at a } \\
\text { similarly named venue in } \\
\text { Bangkok." } 100\end{array}$ & $\begin{array}{l}\text { Although she denied she was } \\
\text { responsibility for twisting the } \\
\text { motto legal action was being } \\
\text { prepared under the Computer } \\
\text { Crime Act. }{ }^{101}\end{array}$ \\
\hline $\begin{array}{l}\text { "Found" wallet } \\
\text { story }\end{array}$ & $\begin{array}{l}\text { A Thai woman claimed on } \\
\text { Facebook that a mysterious } \\
\text { "good citizen had returned her } \\
\text { expensive wallet. }\end{array}$ & $\begin{array}{l}\text { Police stated the case was } \\
\text { about inputting false } \\
\text { information into a computer } \\
\text { system "to cause doubt and } \\
\text { confusion and may be done for } \\
\text { a hidden agenda."102 } \\
\text { Prosecution was proceeding. }\end{array}$ \\
\hline $\begin{array}{l}\text { The Chinese and the } \\
\text { sea urchins }\end{array}$ & $\begin{array}{l}\text { Four Chinese were wrongly } \\
\text { accused of beating sea urchins. }\end{array}$ & $\begin{array}{l}\text { After investigation the police } \\
\text { ascertained that they were, in } \\
\text { fact, moving the sea urchins to }\end{array}$ \\
\hline
\end{tabular}

\footnotetext{
${ }^{96}{ }_{1}$ Ex-soldier arrested for posting alarming message on Facebook (2020).

${ }^{97}$ 'Government dismisses rumors of House dissolution to avert censure debate (2020).

${ }^{98}$ 'PM complains of fake news about his wife's religion (2019).

${ }^{99}$ Ibid.

${ }^{100}$ Ibid.

${ }^{101}$ Ibid.

${ }^{102}$ Woman may face Computer Act charges over 'found' wallet story' (2019).
} 


\begin{tabular}{|l|l|l|}
\hline Case & \multicolumn{1}{|c|}{ Brief Description } & \multicolumn{1}{|c|}{ Reported Action } \\
\hline & $\begin{array}{l}\text { 92 } \\
\text { the beach where they could be } \\
\text { reached by sea water. Police } \\
\text { were planning to locate and } \\
\text { prosecute the online poster for } \\
\text { putting false information into a } \\
\text { Computer system } 03\end{array}$ \\
\hline $\begin{array}{l}\text { The Baht } 12,000 \\
\text { cups of coffee }\end{array}$ & $\begin{array}{l}\text { A deputy party leader shared a } \\
\text { post claiming that the Deputy } \\
\text { Prime Minister was buying cups } \\
\text { of copy for Bt12,000 Three } \\
\text { minutes later he was warned by } \\
\text { somebody it may be a fake; } \\
\text { deleted it and issued an apology. }\end{array}$ & $\begin{array}{l}\text { Within the three minutes } \\
\text { between posting and deleting } \\
\text { somebody had captured the } \\
\text { message and reported it to } \\
\text { police. }\end{array}$ \\
\hline
\end{tabular}

Source: Details as shown in footnotes.

In December 2019 the Minister claimed that people aged 60 and over were the greatest purveyors of inaccurate information online out concern for those close to them. ${ }^{105}$

\section{2) COVID-19 Related Offences}

4) State of Emergency

A State of Emergency came into force on 26 March 2020 under the Emergency Decree on Public Administration in Emergency Situation. ${ }^{106}$ The prohibitions included:

"Reporting or spreading of information regarding COVID-19 which is untrue and may cause public fear, as well as deliberate distortion of information which causes misunderstanding and hence affects peace and order, or good morale of people, are prohibited. In that case, officials will suspend or edit such piece of news. If the case leads to severe impacts, the Computer-Related Crime Act or Emergency Decree on Public Administration in Emergency Situation will be enforced for prosecution. ",107

This prohibition complies with s 9(3) of the Emergency Decree ${ }^{108}$ with the addition of the last sentence which specifies under which provisions prosecution will occur. Human Rights Watch considered that "the government was given a free hand to censor free speech" under the Emergency Decree. ${ }^{109}$

\footnotetext{
${ }^{103}$ 'Chinese wrongly accused of beating sea urchins' (2019).

${ }^{104}$ 'Future Forward deputy meets with police over 3-minute fake post' (2019).

${ }^{105}$ Khidhir (2019).

${ }^{106}$ Emergency Decree on Public Administration in Emergency Situation, B.E. 2548.

${ }^{107}$ Quoted verbatim in: 'Thailand: COVID-19 Clampdown on Free Speech (2020).h 2020).

${ }^{108}$ Emergency Decree on Public Administration.

${ }^{109}$ 'Thailand: COVID-19 Clampdown on Free Speech (2020).'
} 


\section{5) The Good}

In January 2020 a woman observed a patient being transported on a stretcher from Phuket airport and assumed it to be a deceased person. ${ }^{110}$ She posted a photograph on her Facebook page with the caption in Thai "One death at Phuket International Airport \#Chinese". In fact, a person had suffered a mini stroke on arrival and was discharged from hospital the next day. The airport lodged a formal complaint with police to press charges under s14(1) of the of the Computer Crime Act.

Later in month two persons were arrested and charged with separate offences of posting false information on the internet. ${ }^{111}$ In one case the suspect posted a video of a person collapsing in an unrelated incident and claimed it to be connected to coronavirus. In the other case the suspect claimed that a patient had died in hospital in a Pattaya and asked why it was being suppressed. ${ }^{112}$ The information concerning the death was all false.

Not all offenders are prosecuted. Of six cases referred to by the Minister on 30 January four resulted in no prosecutions as the investigators found that they did not have any intention to cause harm so were released with a warning. ${ }^{113}$

On 5 February the Minister for Digital Economy and Society announced that, at that stage, police had arrested six persons from various locations for violation of s14(2) of the Computer Crime Act. ${ }^{114}$ The minister

"explained that releasing and sharing fake news would only cause panic among the public, which will ultimately lead to wrong practices in virus prevention as well as discrimination against people who only have the common flu. 'In the long term, this could affect Thailand's image as incapable of containing the virus and educating the public, which may affect the confidence of foreign investors and tourists in the future,' he added." 115

Four people were arrested in February for spreading fake news about the spread of the COVID-19 virus. ${ }^{116}$ One of the posts claimed that a new coronavirus from Wuhan was spreading in Chiang Mai. An official claimed the fake news caused panic in Chiang Mai.

In March 2020 a women was arrested for falsely posting on her Twitter account that 40 people in her neighbourhood were infected with COVID-19; whereas a check by the Ministry of Health determined that there were none. ${ }^{117}$ "She said she just wanted to warn people who were involved with her business to be careful., 118

\footnotetext{
${ }^{110}$ 'Phuket virus death fake news poster acknowledges Computer Crimes Act charge' (2020).

${ }^{111}$ Boonbandit (2020).

${ }^{112}$ Fake News! Thai woman arrested for saying someone died in Pattaya from coronavirus' (2020).

${ }^{113}$ 'Two charged for spreading fake coronavirus news' (2020).

${ }^{114}$ 'Govt to crack down on dissemination of fake news about coronavirus' (2020).

${ }^{115}$ Ibid.

${ }^{116}$ 'Four people in custody accused of spreading fake news about coronavirus' (2020).

${ }^{117}$ 'Minister pushes for prosecution of woman who put out 'false message' on Covid-19' (2020).

${ }^{118}$ Ibid.
} 
On 26 March police arrested two persons for posting a report on Facebook that police had set up a checkpoint in Bangkok and were fining drivers for not wearing face masks. ${ }^{119}$ They were charged with importing forged data into a computer system or false computer data "in a manner likely to cause damage to that third party or the public." 120

As at 31 March, Thai police were investigating 44 fake COVID-19 websites which were similar to the official government site to ascertain whether what fraud, if any, was being committed. ${ }^{121}$ The ruses included using the correct domain name but changing the extension, misspelling the Thai domain name by using different tone marks ${ }^{122}$ or both.

\section{6) The Bad}

In February the government's "anti-fake news centre" posted that a report by Khaosod Online made a false claim about the COVID-19 contents on the Facebook page of the Thai Embassy in London. ${ }^{123}$ When the publisher approached the centre for clarification it was told that the Facebook page was a fake. The Ministry of Foreign Affairs in Thailand when contacted by the published confirmed that the page was indeed run by its London mission.

On 23 March police arrested and charged a person with violating s 14(2) of the Computer Crime $\mathrm{Act}^{124}$ for a post on his Facebook page that stated that when he landed at Bangkok's Suvarnabhumi Airport he did not encounter any COVID19 screening. He was held without bail for 12 days. The airport operators alleged that the post was not factual and caused public panic and misled people to think that the airport screening was inadequate. ${ }^{125}$

Five negative posts on the government's cash hand out scheme were investigated and were found to be by "those who had filled wrong information in the online form, or by those who had received the Bt5,000 and posted improper content or opinions on social media". ${ }^{26}$ Police were preparing a brief for the prosecution.

\section{8) Discussion}

As has been shown, Thailand has a very aggressive approach to the prosecution of propagators of what Thai authorities consider to be lèse-majesté; criminal deformation; or fake news.

In lèse-majesté cases most of the neither the details nor the sentences are revealed, which appear to be draconian. As reported above, the sentences for

\footnotetext{
${ }^{119}$ Thongtub (2020b).

${ }^{120}$ For example s14.1 as amended by Computer Crime Act (No. 2).

121'Covid-19: Tech police go after dozens of fake websites' (2020).

${ }^{122}$ For instance, using "เราไม่ทิ่งกัน", "เราไม้ทิ้งกัน" or "เราไม่ทิ๋งกัน".

${ }^{123}$ Charuvastra (2020).

${ }^{124}$ Computer Crime Act (No. 2).

${ }^{125}$ 'Thailand: COVID-19 Clampdown on Free Speech' (2020).

${ }^{126}$ IT crime taskforce looking into negative social media posts on cash handout scheme' (2020).
} 
posting a single Facebook message can be up to 10 years cumulative for each message. The prosecution of such cases may also take years.

Often the material prosecuted is probably a very small amount of what would be considered as "subversive" as overseas websites are used to host such materials. Access remains readily available. Those with a Virtual Private Network (VPN) could even circulate the material within Thailand. If, as reported, there has never been a case of lèse-majesté brought by one of the offended parties (i.e. the King, Queen, Crown Prince or Heir-Apparent) why is the offence still on the Statute books?

Criminal defamation also is used as a tool to silence critics. The sentences are particularly severe where there is economic damage whether or not a statement was apparently true. Many of the reported cases of fake news that are being prosecuted are trivial, and thus a waste of valuable police and legal resources. This is often because a government organisation or official has been criticised. It appears that the recent years of a more authoritarian administration have caused government departments and the internet trolls to prosecute rather than exhibiting the 'mai pen rai' (never mind) response of earlier years.

The Thai authorities have been fairly successful in identifying and slowing false news during the COVID-19 pandemic. What is disappointing is the laying of charges over what are really rather petty offences.

The aim of fake news legislation should be to stop the promulgation of fake news, have the information removed and a correction and apology issued. Only serious cases should be prosecuted. Publication of the charges in the press tends to spread the "fake news" rather than suppress it. This would also help to deny the internet trolls their hobby of reporting to police the posting of views that do not agree with their views or those of the monarchy or the government. The action of these trolls is tantamount to persecution. Furthermore, conducting misinformation campaigns by government authorities including the military should be explicitly prohibited.

\section{Conclusions}

The paper has shown that the Thai legislation results in prosecutions that lead to penalties that are draconian when compared to the nature of the offence.

A number of legislative and administrative actions should be undertaken to "make the penalty fit the crime":

a) ideally remove the crime of lèse-majesté from the Thai Criminal Code ${ }^{127}$ or, as a minimum, amend it so that action can only proceed with the written approval of the Monarch or Regent;

b) the only remedy for defamation should be civil action and not criminal action and the Criminal Code should be amended accordingly. ${ }^{128}$ In

\footnotetext{
${ }^{127}$ The Criminal Code s 112.

${ }^{128}$ Ibid s 326.
} 
addition an amendment is required so the action can only proceed with the written approval of the offended party:

c) The Computer Crime $\mathrm{Act}^{129}$ be amended to provide a clear definition of "fake news." For "fake news", civil penalties should be considered with the focus on removal of fake news from the internet, corrections and apologies rather than severe prison sentences: and

d) Amend the Computer Crime Act to include a specific offence of spreading misinformation by a government personnel, including the military, whether in an official or unofficial capacity.

Such changes would lead to a more just system of combatting fake news in Thailand.

\section{References}

Aesop's Fables Interactive Book (adapted from the book "The Aesop for Children: with Pictures by Milo Winter", published by Rand, McNally \& Co in 1919). (Library of Congress).

Aesop. The Shepherd Boy \& the Wolf. In Aesop's Fables Interactive Book (adapted from the book "The Aesop for Children: with Pictures by Milo Winter", published by Rand, McNally \& Co in 1919). (Library of Congress) 43.

Article 19 and The National Press Council of Thailand, (2009). Impact of Defamation Law on Freedom of Expression in Thailand, https://www.article19.org/data/files/pdfs/ analysis/thailand-impact-of-defamation-law-on-freedom-of-expression.pdf.

Boonbandit, T. (2020). 'Two arrested for spreading coronavirus fake news', Khaosod English, 30 January 2020. https://www.khaosodenglish.com/politics/2020/01/ 30/two-arrested-for-spreading-coronavirus-fake-news

Charuvastra, T. (2020). 'Gov't 'Anti-Fake News Center' caught spreading fake news' Kaosod English, 25 February 2020. https://www.khaosodenglish.com/news/cri mecourtscalamity/2020/02/25/govt-anti-fake-news-center-caught-spreading-fakenews.

Chinese wrongly accused of beating sea urchins (2019). Bangkok Post, 23 May 2019. https://www.bangkokpost.com/news/general/1682676/chinese-wrongly-accused-ofbeating-sea-urchins.

Covid-19: Tech police go after dozens of fake websites - Thais trick Thais slipping up in their own language! thaivisa News, 30 March 2020. https://forum.thaivisa.com/topic/ 1156655-covid-19-tech-police-go-after-dozens-of-fake-websites-thais-trick-thaisslipping-up-in-their-own-language.

Editorial Board, 'Thailand's crude attempt to intimidate a journalist' (2020), The Washington Post, 1 January 2020. https://www.washingtonpost.com/opinions/globalopinions/thailands-crude-attempt-to-intimidate-a-journalist/2019/12/31/4462c28e2b46-11ea-9b60-817cc18cf173_story.html.

European Commission (2018). A multi-dimensional approach to disinformation: Report of the independent High level Group on fake news and online disinformation.

${ }^{129}$ Computer Crime Act (No. 2) s 14(1) \& s 14(2). 
Ex-soldier arrested for posting alarming message on Facebook (2020). The Nation Thailand, 10 February 2020. https://www.nationthailand.com/news/30381893?Utm _source=homepage\&utm_medium=internal_referral.

'Fake News! Thai woman arrested for saying someone died in Pattaya from coronavirus', Naew Na (translated by thaivisa.com), 6 February 2020. https://forum.thaivisa.com/ topic/1146940-fake-news-thai-woman-arrested-for-saying-someone-died-in-pattayafrom-coronavirus/.

Farhall, K., Wright, S., Carson, A., Gibbons, A. \& W. Lukamto (2019). 'Political Elites' Use of Fake News Discourse Across Communications Platforms, Int. J. Commun. 13:4353-4375.

Four people in custody accused of spreading fake news about coronavirus. (2020). Thai PBS World, 17 February 2020. https://www.thaipbsworld.com/four-people-

Framework and Joint Declaration to Minimize the Harmful Effects of Fake News. 14th Conference of the ASEAN Ministers Responsible for Information (AMRI) (2018). https://asean.org/storage/2012/05/Annex-5-Framework-Declr-Fake-News.pdf.

Future Forward deputy meets with police over 3-minute fake post (2019). The Nation, 11 March 2019. http://www.nationmultimedia.com/detail/breakingnews/30365579.

Gomez, J. (2019). Vague fake news laws lead to over criminalisation in South East Asia, Commentary in Blog Post, 2 April 2019. https://asiacentre.org/vague-fake-newslaws-lead-to-over-criminalisation-in-south-east-asia/.

Government dismisses rumours of House dissolution to avert censure debate (2020). National News Bureau of Thailand, 20 January 2020. https://forum.thaivisa.com/ topic/1144117-government-dismisses-rumors-of-house-dissolution-to-avert-censuredebate.

Govt to crack down on dissemination of fake news about coronavirus (2020). The Nation Thailand, 6 February 2020. https://www.nationthailand.com/news/30381677.

Haciyakupoglu, G., Yang Hui, J. Y., Suguna, V.S., Leong, D. \& M.F.B.A. Rahman (2018). Countering Fake News: A survey of recent global initiatives (S. Rajaratnam School of International Studies (RSIS), 2018)

Hunt, L. (2012). Thailand's Uncle SMS is dead, ASEAN Beat Blog Post, 9 May 2012/. https://thediplomat.com/2012/05/thailands-uncle-sms-is-dead/.

Hunt, L. (2020). 4 ASEAN States Abusing COVID-19 Emergency Powers, ASEAN Beat Blog Post, 27 April 2020. https://thediplomat.com/2020/04/4-asean-states-abusingcovid-19-emergency-powers.

Indananda, N., Taweepon S. \& A. Wheatley (2017). Copyright litigation in Thailand: overview (Law stated as at 01-Nov-2017) Thompson Reuters Practical Law.

'IO Documents No Longer Secret' (2020). Facebook Blog Post, 26 February 2020.

'IT crime taskforce looking into negative social media posts on cash handout scheme', The National Thailand, 11 April 2020. https://www.nationthailand.com/news/30385786.

Khidhir, S. (2019). Elderly are biggest spreaders of fake news, in The ASEAN Post, 5 December 2019. https://theaseanpost.com/article/elderly-are-biggest-spreaders-fakenews.

Minister pushes for prosecution of woman who put out 'false message' on Covid-19 (2020). The Nation Thailand, 3 March 2020. https://www.nationthailand.com/news/ 30383253.

Office of the High Commissioner for Human Rights (2018). Thailand: UN experts condemn use of defamation laws to silence human rights defender Andy Hall https://www.ohchr.org/EN/NewsEvents/Pages/DisplayNews.aspx ?NewsID=23095\& LangID=E. 
'Opposition alleges army behind cyber-attacks on critics, holds PM responsible' (2020). Thai PBS World, 26 February 2020. https://www.thaipbsworld.com/oppositionalleges-army-behind-cyber-attacks-on-critics-holds-pm-responsible.

'Phuket virus death fake news poster acknowledges Computer Crimes Act charge' (2020) Phuket News, 17 February 2020. https://www.thephuketnews.com/phuket-virusdeath-fake-news-poster-acknowledges-computer-crimes-act-charge-74864.php.

'PM complains of fake news about his wife's religion', Thai PBS World, 17 December 2019. https://www.thaipbsworld.com/pm-complains-of-fake-news-about-his-wifesreligion/.

Quinley, C. (2019). Thai pro-democracy activist faces prison over Facebook post, Al Jazeera, 17 October 2019. https://www.aljazeera.com/news/2019/10/thai-prodemocracy-activist-faces-prison-facebook-post-191017064614724.html.

Smith, R.B. (2019). Harmonisation of laws in ASEAN: The issue of English. In Proceedings of the International Seminar on Politics, Administration and Development (INSPAD2019), Walailak University Thailand, 7-8 November 2019, 273-282.

Sombatpoonsiri, J. (2019). 'Fake News' and Thailand's information wars', ASEAN Beat Blog Post, 3 July 2019. https://thediplomat.com/2019/07/fake-news-and-thailandsinformation-wars/.

Somwaiya, K. (2017). Thailand's five ministerial notifications amended computer crimes act finally come force. https://www.lawplusltd.com/2017/02/amendments-computercrimes-act-thailand-finally-published/.

'Thai activist gets political refugee tag', Bangkok Post, 14 November 2018. https://www. bangkokpost.com/thailand/politics/1575418/thai-activist-gets-political-refugee-tag.

'Thai PM, army deny campaigns on social media to target political opponents', Reuters, 26 February 2020. https://www.reuters.com/article/us-thailand-politics/thai-pm-army -deny-campaigns-on-social-media-to-target-political-opponents-idUSKCN20K1FC.

'Thai police hunt couple behind viral sex toy video', thaivisa News, 20 April 2020 https://forum.thaivisa.com/topic/1160447-thai-police-hunt-couple-behind-viral-sextoy-video/.

'Thailand: COVID-19 Clampdown on Free Speech', Human Rights Watch, 25 March 2020. https://www.hrw.org/news/2020/03/25/thailand-covid-19-clampdown-freespeech.

Thongtub, E. (2020a). Australian, American among four charged for 'Abandoned Phuket Zoo' post, Phuket News, 23 April 2020. https://www.thephuketnews.com/australianamerican-among-four-charged-for-abandoned-phuket-zoo-post-75810.php.

Thongtub, E. (2020b). Two charged for fake news posts of police levying B200 fines for not wearing face masks. Phuket News, 27 March 2020. https://www.thephuketnews. com/two-charged-for-fake-news-posts-of-police-levying-b200-fines-for-not-wearingface-masks-75474.php.

TLHR, (2019a). Changes in Thailand's lèse majesté prosecutions in 2018. Thai Lawyers for Human Rights. https://www.tlhr2014.com/?p=10431\&lang=en.

TLHR, (2019b). At least 25 still confined in prison under Thailand's lèse-majesté law', Thai Lawyers for Human Rights. https://www.tlhr2014.com/?p=13583\&lang=en

'Two charged for spreading fake coronavirus news', The Nation Thailand, 30 January 2020. https://www.nationthailand.com/news/30381310.

United States Department of State, Bureau of Democracy, Human Rights and Labour (2019). Thailand 2018 Human Rights Report. https://www.state.gov/wpcontent/uploads/2019/03/THAILAND-2018.pdf.

'Watch yourself! Court orders Thai held for 12 days after 'fake' Covid-19 post - he is later given bail', in thaivisa, 25 March 2020. https://forum.thaivisa.com/topic/1155731- 
watch-yourself-court-orders-thai-held-for-12-days-after-fake-covid-19-post-he-islater-given-bail/.

'Weaponised defamation', Bangkok Post, 1 December 2018. https://www.bangkokpost. com/opinion/opinion/1585570/weaponised-defamation.

'Woman may face Computer Act charges over 'found' wallet story', The Nation Thailand, 23 June 2019. http://www.nationmultimedia.com/detail/national/30371520

Wongcha-um, P. (2018). Thai court drops royal insult case over ancient king, Reuters, 17 January 2018. https://www.reuters.com/article/us-thailand-lesemajeste/thai-courtdrops-royal-insult-case-over-ancient-king-idUSKBN1F60FD>.

\section{Legislation}

Computer Crime Act B.E. 2550 (2007) (tr tentative) (Thailand).

Computer Crime Act (No 2) B.E. 2560 (2017) (tr Wikisource) (Thailand).

Constitution of the Kingdom of Thailand (B.E. 2560 (2017)) (Thailand, trans Office of the Council of State).

The Criminal Code updated to 2009 (tr Y. V. Yuthankun) (Thailand)

The Criminal Procedure Code (tr Yongyuth V's Yuthankun) (update 2009) 2009 (Thailand)

Emergency Decree on Public Administration in Emergency Situation, B.E. 2548 (2005) (tr State Council) (Thailand) 



\title{
A Right to Access to Medical Records in the Case Law of the Portuguese Courts: Possible Guidelines for future European Court of Human Rights Case Law
}

\author{
By Anatoliy A. Lytvynenko*
}

\begin{abstract}
Patients frequently strive to access their respective medical records before commencing a malpractice action against hospitals or physicians, though the aim of the inspection of these records may extend to other civil litigation or private discovery issues. In contrast to well-known issues within medical law, such as medical malpractice or informed consent, litigation concerning the patient's (and occasionally others, as well) right to inspect their medical records does not possess a rich history in case law, and this lacuna is reflected by the lack of legislative acts and bylaws in some jurisdictions. The litigation regarding access to health records has given rise to various complicated issues that are related to data privacy and medical record-keeping. These may involve matters such as the proprietary status of medical records, the right to third parties' inspection of records or a right to access a deceased relative's medical records, the transfer of medical records from one health-care provider to another and the scope of medical records that are eligible to be inspected. The European Court of Human Rights has also dealt with the issue, most recently in $K \&$ Others $v$. Slovakia, where the Court ultimately recognised the patient's right to inspect their medical records as covered by the scope of Art. 8 of the European Convention of Human Rights. Although the European Court has dealt with the issue intermittently, there are still many unresolved aspects that may be brought before the Court. This paper presents the general issues of access to medical records' litigation, including a case study of judgments promulgated by the courts of Portugal on the subject, wherein the Portuguese courts adopted a series of principles that may be crucial for further litigation not only in Portuguese courts or the national courts of neighbouring states, but in international Human Rights Courts as well.
\end{abstract}

Keywords: Access to Medical Records; Medical Confidentiality; Data Privacy; Medical Records.

\section{Introduction - General Assumptions on the Right to Medical Records Inspection}

Over the last decades, the jurisprudence of various civil and common law jurisdictions has reflected the development of the concept of a patient's right to decision-making and autonomy. This is, inter alia, was accompanied by their right

*PhD (Law) Candidate, Ivan Franko National University of Lviv, Ukraine.

E-mail: anat.lytvynenko@gmail.com. 
to inspect their medical records, which commonly include information regarding their current state of health, treatments, analyses, diagnostics, and prognosis of their future health condition. ${ }^{1}$ In fact, the patient's personal data may include a large amount of recorded textual data, or other physician-identifiable data recorded by means of diagnostics, which are not necessarily textual ${ }^{2}$ but may be identifiable by expert physicians or by specific techniques. For instance, a relatively recent judgment by the Stockholm Court of Appeals decreed that a list of medicines prescribed to a patient was also considered part of their medical data. ${ }^{3}$ In some civil law states, such as Germany, this right is not codified and is determined by the Courts as a right deriving from the contract between the patient and the physician or hospital. ${ }^{4}$ Common law states, such as England, have adopted a socalled "common-law" right to access medical records, ${ }^{5}$ though commentators had claimed that even in common law situations, the purpose of accessing these records has rarely been for malpractice litigation. ${ }^{6}$ Some states, such as Portugal, have adopted legislation that guarantees the right to access medical records, later considering them as administrative records (in the same way as some United States Courts recognised medical records as quasi-public, ${ }^{7}$ or public records). ${ }^{8}$ As a result, access to these records may be obtained based on the law regarding access to administrative documents. ${ }^{9}$ However, in most cases where the prospective plaintiff requests that the hospital allow them access to their health records, this occurs in preparation for a malpractice action. ${ }^{10}$ These include:

\footnotetext{
${ }^{1}$ In Germany, courts referred to medical records as data concerning the patient's current condition and the prognosis for the future, see judgment of the Bremen's Higher Regional Court, OLG Bremen, 31.07.1979 - 1 U 47/79, at para. 15. In Portugal, this definition seems to be a bit broader, see. Unidade de Saude A c. B..., Acordao do Supremo Tribunal Administrativo, 08.08.2018, Processo 0394/18, Sec. II, 1-11. In more contemporary case law of German courts, they extended the definition by adding, that "In addition to the medical, objectifiable findings and reports on [the patient's] treatment measures, such as surgery and medication [it includes] the description of subjective perceptions [obviously, of the physicians] and personal [physician's] impressions of the patient", see $O L G$ Karlsruhe, Urt. v. 16.08.2017 - 7 U 202/16, at para. 22.

${ }^{2}$ See my comments concerning defining "medical data" in Lytvynenko (2020a) at 102-103 and cases cited therein.

${ }^{3}$ Socialnämnden i Danderyds kommun, Kammratt Stockholm, 17 Sep. 2014, fall 5348-14 (2014)

${ }^{4}$ Particularly affirmed by the Decision of Federal Supreme Court of Germany, BGH 28.11.1982, VI ZR 222/79, at para. 15; see also the following judgments: $A G$ Weltzar, 15.08.1978 - 3C 707/78, para. 8-9 та 15; LG Gottingen, 16.11.1978 - 2 O 152/78, para. 9-10, 16; BGH, 23.11.1982; VI ZR 222/79, para. 14-15; AG Essen, 21.04.1997 - 12 C13/97, para. 5-6; OLG Munchen, 19.04.2001 - 1 U 6107/00, para. 21.

${ }^{5}$ Ex parte Martin, [1995] 1 W.L.R. 110, 117-119.

${ }^{6}$ Feenan (1996) at105-107.

${ }^{7}$ Pyramid Life Insurance Co. v. Masonic Hospital Assn. of Payne County 191 F. Supp. 51, 54 (W.D. Okla. 1961).

${ }^{8}$ Oliver v. Harborview Medical Center, 94 Wash.2d 559, 564-567 (1980).

${ }^{9}$ Unidade de Saude A c. B..., Acordao do Supremo Tribunal Administrativo, 08.08.2018, Processo 0394/18, Sec. III, 2.

${ }^{10}$ In fact, such purpose is the most common reason for an inspection of medical records among common law and civil law states. For instance, see England: Dunning v United Liverpool Hospitals' Board of Governors, [1973] 1 W.L.R. 586; Deistung v South West Metropolitan Regional Hospital Board, [1974] 1 W.L.R. 213; Davidson v Lloyd Aircraft Services Ltd., [1974] 1 W.L.R. 1042; and e.g. Germany, see. e.g. OLG Köln, 12.11.1981: 7 U96/81, at para. 18. The same applies to Portugal:
} 
1. Medical malpractice action, such as an action for battery (unauthorised surgical intervention with no informed consent) ${ }^{11}$

2. Access to a deceased relative's health records so as to determine if the cause of death is a result of the negligence of healthcare workers; ${ }^{12}$

3. Access to the deceased testator's health records in order to challenge the validity of their will, or specific codicils of the will. Such judgments could be found in the case law of the Netherlands ${ }^{13}$ and Germany; ${ }^{14}$

4. A private discovery of facts concerning a plaintiff's treatment, e.g. in mental asylums (this is quite rare in case law, though there are a number of examples from Germany); ${ }^{15}$

5. A plaintiff's wish to uncover the identity of their biological parents; ${ }^{16}$

6. A necessity to produce medical records for a divorce trial before a diocese court. As I discussed in a recent paper, this occurs mainly in Italy. ${ }^{17}$

In many cases, inspecting medical records is prohibited for various reasons. For instance, in the mid-1970s, English Courts determined that the plaintiff should not be allowed to directly inspect their medical records, as this was a right reserved exclusively for lawyers or appointed medical advisors. ${ }^{18}$ English courts were eager to follow the then-existing hospital practices and decided not to grant plaintiffs the right to read or copy material from their medical records. This decision was based upon the argument that laymen may not properly understand the medical documentation, the prognosis of the patient's health condition may be too harsh to be properly communicated, the plaintiff or their relatives may find them embarrassing and lastly, some records may be highly confidential, which if breached, may prevent doctors from expressing their views "fully and frankly."19 Much of this position was also adopted by the Portuguese courts, though later in this paper I will discuss certain specific restrictions elaborated upon by these

Unidade de Saude A c. B..., Acordao do Supremo Tribunal Administrativo, 08.08.2018, Processo 0394/18, Sec. III, 4.

${ }^{11}$ See, e.g. the judgment of the European Court of Human Rights in the case of K. H. \& Others $v$. Slovakia, App. no. 32881/04, Judgment of 28 March 2009, at para. 8-9.

${ }^{12}$ See Judgment of the Federal Supreme Court of Germany of 1983, BGH, 31.05.1983 - VI ZR 259/ 81 at para. 17.

${ }^{13}$ Hoge Raad, 20 April 2001, NJ 2001, 600; No. C99/030 HR, para. 3.1; 3.2 (facts); Rechtbank Arnhem, 8 August 2005, Prg. 2005, 195, No. 128531 (see Section "Dispute" para. 1-4; "The assession of the dispute", para. 4 (including the subparagraphs).

${ }^{14}$ See $O L G$ Düsseldorf, Urt. v. 29.03.2000, Az.:3 Wx 436/99 at para. 12-19.

${ }^{15}$ See judgment of the German Federal Supreme Court, BGH, 02.10.1984 - VI ZR 311/82, originally page 5-8 from the court report.

${ }^{16}$ In one of my recent works, I have described the concept of "a right to anonymous birth" from its very beginning in French and Belgian case law originating from mid- $19^{\text {th }}$ century, as well as an analysis of contemporary case law on the subject from United States and Italy, as well as two judgments of the European Court of Human Rights. See in detail Lytvynenko (2020a) at 124-131.

${ }^{17}$ F.M. contro Casa di Cura Polispecialistica (...) e M.I., Consiglio di Stato, Sezione V., sentenza 28 settembre 2010, no. 7166.

${ }^{18}$ See Deistung $v$ South West Metropolitan Regional Hospital Board, [1974] 1 W.L.R. 213, at p. 215-217.

${ }^{19}$ See McIvor v Southern Health \& Social Service Board, [1978] 1 W.L.R. 757, at p. 760-761. 
courts. ${ }^{20}$ German courts, on the other hand, seem to be more liberal regarding the restriction of access to medical records. In the decision of the Higher Regional Court of Cologne (Oberlandesgericht Koln) of 1981, for example, the Court determined that in the case of a patient lacking sufficient knowledge in interpreting medical records, they are free to employ lawyers and medical advisors for assistance. $^{21}$ This was not the first case where a German court rejected the argument that it was permissible to restrict the communication of data to a patient based on the argument that a patient might not be able to properly understand their record. In 1978, an appellate court in Gottingen held that the plaintiff was entitled to employ advisors to decipher and explain their medical records. ${ }^{22}$ In its 1982 judgment, the German Federal Supreme Court, affirming the position of the aforementioned court of Cologne, also held that often medical records are intelligible even to laymen. ${ }^{23}$ This court found that the only applicable restriction regarding access to a patient's medical records may concern communications between physicians, involving supposed diagnoses or containing subjective language. The Court thus agreed that scientific findings might be accessible to patients. ${ }^{24}$ However, German courts (particularly, the Federal Supreme Court) affirmed that there may be some categories of medical data that merited specific or partially restricted access, referring mainly to psychiatric records ${ }^{25}$. In such cases, the plaintiff may be compelled to justify their reasons for requesting access to medical records (e.g. to produce them within the framework of malpractice litigation), ${ }^{26}$ though in ordinary circumstances, not all courts may ask for such justification. Such was the position of the German Federal Supreme Court in two 1980s judgments. ${ }^{27}$ This form of justification is also relevant to cases where the relatives of a deceased person desire to examine the records so as to determine the cause of their death and subsequently sue the hospital for negligence. ${ }^{28}$

\section{A Brief History}

While some commentators believe that the right to access medical records was not known within the framework of common law before the 1960s or 1970s, ${ }^{29}$ the long-standing interest in this subject is demonstrated by hospital record-

\footnotetext{
${ }^{20}$ B c. C., Acordao do Tribunal da Relacao do Porto, 08.09.2019, Processo No. 2147/18.T8AGD. P1, Sec. II.

${ }^{21}$ OLG Koln, 12.11.1981, 7U 96/81 at para. 24-25.

${ }^{22} L G$ Gottingen, $16.11 .1978-2 \mathrm{O} 152 / 78$ at para. 9-16.

${ }^{23} B G H, 23.11 .1982$; VI ZR 222/79 at para. 17-27.

${ }^{24}$ Same, see BGH, 23.11.1982; VI ZR 222/79 at para. 17-27 and 30.

${ }^{25}$ See judgment of the German Federal Supreme Court, $B G H, 06.12 .1988$ - VI ZR 76/88, at para. 7, 9-10.

${ }^{26} L G$ Saarbrucken, 20.09.1995 - $16 \mathrm{~S}$ 1/93, at para. 7-8

${ }^{27}$ See. $B G H, 31.05 .1983$ - VI ZR 259/81, at para. 8; $B G H, 02.10 .1984$ - VI ZR 311/82, original judgment report at p. 5 .

${ }^{28}$ See judgment of the German Federal Supreme Court of 1983, BGH, 31.05.1983 - VI ZR 259/81, at para. 19-20.

${ }^{29}$ See comment of the House of Lords in McIvor v Southern Health \& Social Service Board [1978] 1 W.L.R. 757 at p. $760-761$.
} 
keeping practices. In countries such as Germany and Austria, hospital recordkeeping practices began no later than the seventeenth century, and were monitored by local authorities in order to avoid malpractice. ${ }^{30}$ However, issues concerning the validity of medical certificates, as well as the forgery of medical records, can be found in the earlier case law of France. ${ }^{31}$ In the nineteenth-century jurisprudence of France, medical secrecy was deemed as non-negotiable, and the courts were reluctant to recognise exceptions until the early twentieth century. ${ }^{32} \mathrm{In}$ the late nineteenth and early twentieth century, the French courts found that in certain circumstances, such as proving an infant's cause of death ${ }^{33}$ or challenging the validity of a will, ${ }^{34}$ producing medical records was permissible and did not contradict the rules of medical secrecy. ${ }^{35}$ The Belgian rules regarding medical confidentiality seem to be less stringent, ${ }^{36}$ and as far back as 1855 , the Belgian Cassational Court denied a physician the right to conceal the identity of the mother of an illegitimate child. ${ }^{37}$ In other cases, where healthcare workers applied to the court to obtain remuneration for the medical care they had provided to a deceased person, the plaintiffs were prohibited from discussing the symptoms of the deceased's last disease before court experts, as this would breach medical confidentiality. $^{38}$

Another, more complicated issue, was the patient's right to control the transmission of their medical records to third parties, enterprises, or public bodies. For instance, in a case resolved by the Lyon Court of Appeals in 1909, a factory worker sued a physician for entering the fact that he had contracted syphilis into his medical record and delivering it to the factory's insurance fund, preventing him from receiving indemnities for his treatment and disability. The Court held that it was not a violation of medical secrecy to do so; interestingly, the plaintiff did not sue the physician for violation of medical secrecy, but for misdiagnosis. ${ }^{39}$ In a judgment of the Swiss Federal Tribunal from 1917, a misfortunate serviceman fell

\footnotetext{
${ }^{30}$ Gründling (2011) at 32-35.

${ }^{31}$ Min. Publ. c. Doumayrou, Cour de Cass., Cham. crim. 6 Mai 1836, Dall. Per. 1837 I 246.

${ }^{32}$ See in particular Lytvynenko (2020a) at 106-110 and cases cited therein.

${ }^{33}$ Carron c. Vallaton, Cour d'Appel de Lyon, 24 Mars. 1876, Sirey 1877 II 200.

${ }^{34}$ Cons. Aubertin c. v. Perrin, Trib. de Bar-Le-Duc, 15 Oct. 1913, Sirey 1914 II 13.

${ }^{35}$ But at the same time, it should be denoted that the rules of medical secrecy was not always consistent among all the French courts. For instance, in Bousquet c. Compaigne le Gresham, Cour de Cass., Cham civ., 1 Mai 1899, Dall. Per. 1899 I 585, 587, the French Cassational Court excluded physician's testimony concerning the insured man's ailment (which, if found to be admissible, could eliminate plaintiff's claim in the policy repayment, as the insured man died owing to health complexification - this case is commented upon in one of my recent works, Lytvynenko (2020a) at 107.

${ }^{36}$ In the "trial of duellants", dated 1845, the Brussels Court of Appeal dealed with a case where a doctor who assisted a wounded duellant (in fact, the duel, being already illegitimate in Belgium those days, was conducted between two noblemen - Baron d'Hogvorst and Albert Joseph Goblet d'Alviella), refused to answer the question concerning the character of the wound and similar interrogations by the court. He was prosecuted and made to testify, Min. Publ c. Seutin, Cour d'Appel de Bruxelles, 25 mai 1845, Pas. 1845 II 307, 307-308.

${ }^{37}$ Bessems c. Le Ministere Public, Cass. 20 juillet 1855, Pas. 1855 I 303, 305-307; 308-309.

${ }^{38}$ Bernardine de Neef c. Camille Moreau et Consorts, Cour d'Appel de Bruxelles, 24 mars 1905, BJ 1905.530, 530-532.

${ }^{39}$ G. c. R., Cour d'Appel de Lyon, 16 juin 1909, Dall. Per. 1910 II 123, 124-125.
} 
ill after returning from service. His doctor and the doctor's assistant concluded that his illness might be a result of the complications of alcoholism and delivered copies of the plaintiff's medical record to his relatives. The man sued the doctor and his assistant for disclosing his record to his relatives, demanding $5000 \mathrm{CHF}$ and the production of the original medical documents. In addition, it turned out that the doctor's assistant (the second defendant) reached the wrong conclusion concerning the cause of the plaintiff's illness, as subsequently the plaintiff's physical situation improved. The trial court held that the physician acted in good faith and had no intention of harming the plaintiff, despite having entered a misdiagnosis in the medical certificate, and decided in favour of the defendants. On appeal, the Federal Tribunal found that the defendants violated Art. 28 of the Swiss Civil Code (Code Civile Suisse) ${ }^{40}$, but chose not to compel them to pay damages, as the Court found that there was no significant gravity in the acts of the defendants, though the Court did obligate them to provide the plaintiff a copy of the original certificate. ${ }^{41}$

In the United States, the first actions against hospitals and physicians requesting the production of medical records occurred in the late 1930s and were entirely dictated by the plaintiff's wish to produce evidence for malpractice litigation. $^{42}$ This soon became the most common, and, in fact, nearly the only reason, ${ }^{43}$ for requesting medical records not only in the United States. By the early 1970s, this was also true for England. ${ }^{44}$

Some countries, such as Germany ${ }^{45}$ and Austria, ${ }^{46}$ held that the right to view medical records derives from the contract between the physician/hospital and the patient, which has never been codified. Some German courts have deemed that the patient may obtain their medical records even though the contract may not necessarily contain provisions regarding the patient's right to view their medical records. ${ }^{47}$ Much has been written about the implications of the patient-physician relationship, ${ }^{48}$ which many agree has always been contractual by legal nature both in common law $^{49}$ and civil law jurisdictions. Switzerland ${ }^{50}$, Germany ${ }^{51}$ and

\footnotetext{
${ }^{40}$ RO 210, Code civil suisse du 10 decembre 1907, Art. 28.

${ }^{41}$ H. c. M. et V., Arret de la Ire Section civile du 25 octobre 1918, BGE 44 I 322, 325; 327-328

${ }^{42}$ See for instance Lytvynenko (2019) at 202.

${ }^{43}$ However, in some instances, access to medical records (especially to third parties) was restricted to avoid abuse of process, see, e.g. Church of Scientology v DHSS, [1979] 1 W.L.R. 723, 728 onward.

${ }^{44}$ See., for instance, the case of Dunning vUnited Liverpool Hospitals' Board of Governors, [1973]

1 W.L.R. 586.

${ }^{45}$ See particularly the decision of German Federal Supreme Court, BGH, 23.11.1982; VI ZR 222/79, at para. 15 .

${ }^{46}$ See decision of the Austrian Supreme Court (Oberster Gerichthof), OGH 23.5.1984, 1 Ob 550/84.

${ }^{47}$ See decision of the German Federal Supreme Court, BGH, 31.05.1983 - VI ZR 259/81, at para. 12

${ }^{48}$ See Kenna (1973) at 322.

${ }^{49} \mathrm{~A}$ good example in $20^{\text {th }}$ century US case law is Agnew v. Parks, 172 Cal. App. 2d 756, 764 (1959). In an early Canadian case, Lavere v Smith's Falls Public Hospital, 26 D.L.R. 346 (1915), the Supreme Court of Ontario discusses contractual liability of hospitals for negligent care and treatment to patients, and gives various examples of early English, Irish, Scottish and US case law on the subject, see particularly from page $351\left(26^{\text {th }}\right.$ vol. of Dominion Law Reports, Ser. 1).

${ }^{50}$ Meister c. B., Trib. Federal Suisse, 9 decembre 1892, Sirey 1893 IV 16.

${ }^{51} R G$ (Reichsgericht), 27.05.1908 - Rep. VI 484/07, at para. 3; 5.
} 
France $^{52}$ recognised this from a very early date, especially with the framework of civil law. Interestingly, federal legislation in Germany has only recently defined the treatment contract, and no mention of access to medical files exists. ${ }^{53}$ The German courts consider it an implied case-law right. ${ }^{54}$ Some civil law states, such as Germany, recognised the right to inspect medical records as part of the patient's informational right to self-determination in the late 1970s, which also marks the beginning of the development of case law on the subject.

The United Kingdom's approach to the matter is based upon sec. 32 of the Administration of Justice Act 1970, which enabled access to medical records. Before the adoption of this legislation, it was only possible to request the production of medical records with a subpoena. ${ }^{55}$ In rare instances, the issue of producing medical records for malpractice litigation was also related to by the Scottish courts, ${ }^{56}$ while the European Court of Human Rights discussed it several times. In the trial of Gaskin against United Kingdom (1989), a young man, who had been in the custody of various municipal bodies in the 1960s and 1970s, was reported to have various health complications, including psychiatric problems. He was unable to find a job and decided to sue the local authorities in Liverpool, blaming them for negligent care. In order to obtain the required evidence, he applied to the court requesting access to all the relevant documents held by the municipal bodies, but was refused and lost the suit to the Liverpool City Council. The English Court of Appeals then held that the public interest in preserving a plaintiff's medical records in a fully-confidential mode supersedes the plaintiff's private interest in commencing a medical malpractice action. ${ }^{57}$ This was based upon the regulations adopted by the government, which determined that access to medical files could only be granted if the contributor consented to their release, which was often impossible. The European Court of Human Rights found that the plaintiff had no independent body to appeal to, such as an institution, which could weigh their interests and the public interest in medical record confidentiality equally. Instead, the actual balance was moved towards the contributors. The Court found that such measures were not compatible with the test of a "democratic society". The absence of an independent body to determine issues concerning access to medical records was found to be a violation of the plaintiff's right to privacy, guaranteed by the Convention of Human Rights. ${ }^{58}$

The trial known as M.G. against United Kingdom (1997) was quite similar. The plaintiff was an unfortunate man who wished to obtain knowledge about his childhood, the abuse administered by his father and additional related issues. After

\footnotetext{
${ }^{52}$ Beltzer c. Hospices de la ville d'Auxonne, Cour d'Appel Dijon, 18 mars 1903, Sirey 1906 II 17 , 17-18.

1. ${ }^{53}$ BGBI. I 2013 S. 277, § 630a, Vertragstypische Pflichten beim Behandlungsvertrag.

${ }^{54}$ See decision of the German Federal Supreme Court, BGH, 23.11.1982; VI ZR 222/79, at para. 15.

${ }^{55}$ Davidson v Lloyd Aircraft Services Ltd. [1974] 1 W.L.R. 1042, 1045.

${ }^{56}$ See., Glacken v. National Coal Board, 1951 S.C. 82, 83-84 (Court of Sessions, Nov. 21, 1950); Boyle v. Glasgow Royal Infirmary and Associated Hospitals, 1969 S.C. 72, 81-83 (Court of Sessions, Nov. 22, 1968).

${ }^{57}$ Gaskin v Liverpool City Council, [1980] 1 W.L.R. 1549, 1553-1555 [1979 G. 2754].

${ }^{58}$ Gaskin v United Kingdom, [1990] 1 FLR 167, App. No. 10454/83, Judgment of 7 July 1989, para. 19-28; 34-37; 42-45; 46-49; 50-53.
} 
he was granted access to a limited number of records, he decided to commence a lawsuit for negligent care in his childhood, but the medical records and other documents extant from his earlier life were not sufficient to prove negligence. He therefore desired to gain access to additional documents, but the local social services refused his request. At the trial before the European Court, the defendant's representatives acknowledged that they hadn't given him some documents, claiming this was necessary in order to avoid a breach of his siblings' privacy. However, they denied possessing documents confirming his father's abuse or other information that he requested for the negligence action. At first, the Court determined that the acts of the defendant did not contradict the legislation and case law of the United Kingdom, but at the same time, it affirmed that the plaintiff's legitimate interest in receiving his archival records was as that of the plaintiff's in the case of Gaskin. Since the defendant had brought the actual folder containing the plaintiff's records before the Court, the Court had the opportunity to compare the real and actual amount of records that had been supplied to the plaintiff before the lawsuit had commenced. Like Gaskin, the Court found that the plaintiff also had no independent institution to appeal to, though he would have had such an opportunity after the enactment of the Data Privacy Act 1998 on March 1, 2000. Therefore, the Court decided in favour of the plaintiff. ${ }^{59}$

A decade later, another suit was brought before the European Court concerning the subject. In the case of K. H. \& Others v. Slovakia (2009), eight female plaintiffs found themselves sterile after having given birth and hired a lawyer to inspect their medical records, which they planned to use as evidence at a malpractice litigation against their respective hospitals. The lawyer was refused access to the medical records, and the plaintiffs applied to two trial Courts (in Presov and Krompachy respectively), which allowed their lawyer limited access to the documentation, though photocopying was prohibited. They lost their appeal, and the Presov Court held that courts are competent to subpoena medical records within the proceedings. Later, after the adoption of a new law in Slovakia, the plaintiffs were allowed to inspect their medical records, and one of the women found a short recorded item confirming that she had undergone sterilisation, though her entire medical record had been lost. The European Court, having examined the trial facts, affirmed that the right to inspect medical records is a constituent of the plaintiffs' right to privacy, and thus is guaranteed under Art. 8 of the European Convention of Human Rights. In short, the Court said that it was necessary to define whether such a restriction of access to medical files was compatible with "abuse" (meaning abuse of process). Having done so, the Court found that photocopying the records would not constitute "abuse" in such a case, and concluded that the enactment of a new law would not change the judgment. As the action was filed upon Art. 6, 8 and 13 of the Convention, the Court had to examine each count. The Court determined that the plaintiffs' right to privacy was violated by the defendant, and proceeded to examine whether the claim was actionable upon Art. 6 of the Convention. It held that the medical files requested by the plaintiffs were vitally important as evidence for commencing malpractice

${ }^{59}$ M. G. v United Kingdom, [2002] F.C.R. 289, App. No. 39393/98, Judgment of 24 September 2002 , at para. $9-17 ; 32-32 ; 34-36$. 
litigation, and that the national Courts did not justify the limited access to medical records adequately. The Court had no choice but to find a violation of Art. 8 of the Convention of Human Rights as well, and deemed it unnecessary to examine the count upon Art. 13, as a violation of Art. 6 and Art. 8 had already been affirmed. ${ }^{60}$ Such cases were also brought before the Court of Justice of the European Union, mainly in the late 1970s and early 1980s. These were mostly litigations between ex-EEC employees and EEC bodies, primarily connected with complaints concerning the plaintiff's unfitness to perform the duties placed upon the desired position in the EEC bodies. ${ }^{61}$ In the 2010s, similar cases were adjudicated by the currently-defunct European Civil Service Tribunal, a specialised court within the European Court of Justice (2005-2016). ${ }^{62}$

\section{Portuguese Legislation and Case Law on the Right to Access to Medical Records}

The Portuguese legislation has a number of provisions guaranteeing a right to the inspection of medical records, which involve several laws and bylaws. The main law regulating the subject is the so-called "health information law" (Lei No. 12/2005, "Informação genética pessoal e informação de saúde", or literally "personal genetic information and health information"), enacted in January 2005, which regulates the basic issues regarding access to health information. Separate issues of access to medical records are covered by Lei No. 15/2014 ("Lei consolidando a legislação em matéria de direitos e deveres do utente dos serviços de saúde" - in English "law consolidating legislation on the rights and duties of consumers of healthcare services") as well as LADA-2016, or the law on access to administrative documents, officially Lei No. 26/2016 ("Aprova o regime de acesso à informação administrativa e ambiental e de reutilização dos documentos administrativos" - in English "confirmation of the procedure for access to administrative and environmental information and the reuse of administrative documents"), inasmuch as Portuguese courts consider medical files to be administrative documents. ${ }^{63}$ Additional legal bases for the production of medical records were cited by the courts, involving data protection legislation and some secondary bylaws.

The first Portuguese case to examine the right to access medical records was adjudicated by the Porto Court of Appeals (Tribunal Relacao do Porto). The facts were simple. The plaintiff was involved in a road accident in which he was injured and suffered a partial disability, and desired to receive compensation for his

\footnotetext{
${ }^{60}$ K.H. \& Others v. Slovakia, App. no. 32881/04, Judgment of 28 March 2009, para. 8-9, 10, 11-19, 24-25, 26-27, 38-43, 50-58, 65-69, 73.

${ }^{61}$ Alessandro Moli v. Commission of European Communities, Judgment of 27 October 1977, Case No. 121/76 [1977] ECR 1971, 1978-1980; Emma Mollet v. Commission of European Communities, Judgment of 13 April 1978, Case No. 75/77, [1978] ECR 897, 907-908; Miss M. v. European Commission, Judgment of 10 June 1980, Case No. 155/78 [1980] ECR 1798, 1811-1812.

${ }^{62}$ V. v. European Parliament, Case F-46/09, Judgment of 5 July 2011, para 110 - onward.

${ }^{63}$ Unidade de Saude A c. B..., Acordao do Supremo Tribunal Administrativo, 08.08.2018, Processo 0394/18, Sec. III, 2.
} 
injuries from a local insurance company. He requested his clinical records from a hospital (unnamed in the report) as evidence and was refused. As he intended to use his medical records as trial evidence, he turned to the Court, asking for a court order to compel the hospital to produce these documents. The Court affirmed that the plaintiff had a right to inspect the records and requested that the plaintiff appoint a doctor, to whom the records should be sent (in later case law, this was deemed not to be strictly necessary) ${ }^{64}$ The Court agreed that the provisions of Art. 2-3 of Lei No. 12/2005 guaranteed that health-related information was indeed the property of the person concerned, but at the same time, is not possessed by them, but rather is in the possession of healthcare institutions. Healthcare providers are the repositories of the health records and have a duty to protect their confidentiality, preventing their inspection by third parties, unless authorised to do so by law. For this reason, the plaintiff was free either to keep his medical information confidential at a hospital, or to disclose it to whomever he wished, such as an insurance company or a court of law. The Court thus determined that the plaintiff had a right to request his medical records - either for personal use or to use as evidence in trial, as he was free to dispose of his medical data as he wished. ${ }^{65}$

The central case for Portuguese jurisprudence is the decision of the Supreme Administrative Court of Portugal (Supremo Tribunal Administrativo) in the case of Bernardo ... c. Santa Casa da Misericordia de Lisboa, ${ }^{66}$ which was the hospital's appeal against a decision in favour of the plaintiff). In the given case, the plaintiff «B» was the son of a man, «C.», who was hospitalised with a severe traumatic brain injury, which occurred in June 2014. The father sustained a leftside tetraparesis, as well as speech, behaviour and swallowing disorders. As his father was unable to communicate, the plaintiff and his mother, «D.», as the father's guardians, decided upon all aspects of his treatment. In August 2016, the plaintiff's father underwent nail extraction surgery. Through his lawyer, the plaintiff requested that the hospital provide photographs and other medical records concerning the clinical episode which culminated in this operation. When the hospital did not respond to this request, the plaintiff applied to CADA (Committee on Access to Administrative Documents), complaining that he had not received the requested documents. The committee issued an opinion that the hospital should provide the medical records, but the hospital refused to do so, writing in a letter to the plaintiff's mother, «D.», that the plaintiff had not justified his interest in accessing the medical records, which are subject to confidentiality, and therefore the hospital would not provide any information to a third party. ${ }^{67}$ A subsequent

\footnotetext{
${ }^{64}$ See. $B$ c. C., Acordao do Tribunal da Relacao do Porto, 08.09.2019, Processo No. 2147 / 18.T8AGD.P1, Sec. II.

${ }^{65}$ Acordao do Tribunal Relacao do Porto, 10.03.2008, Processo No. 0850591, Sec. II.

${ }^{66}$ This case name was used in the report of the South Central Administrative Court of Appeals of Portugal. The court report from the Supreme Administrative Court used the name Unidade de Saude A c. B. See Bernardo ... c. Santa Casa da Misericordia de Lisboa, Acordao do Tribunal Central Administrativo, 31.01.2018, Processo 353/17.BESNT.

${ }^{67}$ Unidade de Saude A c. B..., Acordao do Supremo Tribunal Administrativo, 08.08.2018, Processo 0394/18, Sec. II, 1-11.
} 
request was dismissed, after which the plaintiff decided to apply to the court and request that a subpoena be issued for the medical records. ${ }^{68}$

The Administrative Court of Sentra (Tribunal Administrativo e Fiscal Sintra, TAF Sintra) ordered the hospital to produce the documents, confirming that the plaintiff had a legitimate interest in obtaining his father's medical records. The defendant appealed the judgment at the South Central Administrative Court (Tribunal Central Administrativo Sul, TCAF), losing the appeal. The appellate court found that the son needed the medical records as a guardian of a sick or disabled person so he could decide whether or not to file an action against the hospital for malpractice. Therefore the plaintiff was justified in his request to inspect his father's medical records. ${ }^{69}$ The hospital appealed this judgment as well, turning to the Supreme Administrative Court. The Supreme Administrative Court determined that the action involved a situation in which the health information was not the property of the plaintiff, though it did belong to his father. The Court, analysing the national legislation, confirmed that the term 'health data' covers all the information directly or indirectly linked to the current-day health condition of a person, or presumable future condition, whether they are alive or deceased, as well as their clinical history. ${ }^{70}$ These health records are the property of the person concerned (the patient), while the hospitals are the repositories (holders) for the records, and the person concerned has a right to access their health records. Third parties may have access to this information with the holder's consent. ${ }^{71}$ Obviously, the law imposes a duty of confidentiality on the hospitals. The court referred to art. 2 (1) and 5 (1) of Lei No. 26/2016 (LADA-2016), upon which the citizens have a right to access administrative documents concerning their existence, and hospital records fall within the scope of nominative administrative documents; thus, the procedure is due under: Art. 3 (b); 6 (5); 7 of Lei No. 26/2016; art. 3 (a); 5 (1) (a); 11 (5) of Lei No. 67/98 (law on data protection); Art. 2, 3, 4 of Lei No. 12/2005. In order to further clarify this matter, the Supreme Administrative Court announced a set of rules concerning access to medical records and their proprietary status:

1) 'Health-related personal data' refers to all the information covering facts directly or indirectly linked to one's health;

2) The health records are the property of the patient concerned, and the hospitals (or, as referred to in the judgment, health system units) are the repositories of these records;

3) The possessor of the records has a right to inspect them (unless prohibited by law, e.g. where it may be harmful to the patient). In any case, they must state the purpose of the inspection and the type of health records they wish to inspect;

\footnotetext{
${ }^{68}$ Ibid, Sec. II, 11-13.

${ }^{69}$ See. Bernardo ... c. Santa Casa da Misericordia de Lisboa, Acordao do Tribunal Central Administrativo, 31.01.2018, Processo 353/17.BESNT, Sec. II.2, 1.2.

${ }^{70}$ Unidade de Saude A c. B..., Acordao do Supremo Tribunal Administrativo, 08.08.2018, Processo 0394/18, Sec. III, 2.

${ }^{71}$ Ibid, Sec. III, 2.
} 
4) Third parties may access the health records with the consent of the holder, only to the extent to which they consented in a designated document;

5) The access to health records is provided to the holder through a physician who will serve as an intermediary, if so requested;

6) If it is impossible to ascertain the will of the patient concerning access to their records, this will be accomplished by a physician who will serve as an intermediary;

7) In case of third party access, they must demonstrate that their request has a relevant direct, personal, legitimate and constitutional protected interest. Once this is accomplished, the court (in case a trial ensues) shall consider the case in the context of the principle of proportionality of fundamental rights (presumed as data privacy) and the principle of open administration justifying access to administrative documents (health records).

8) Only information necessary for the third party's legitimate interests may be communicated (i.e. not all the information contained in health records);

9) Hospitals (health system units) must prevent unauthorised access by third parties, based upon data protection legislation ${ }^{72}$.

The court considered that the plaintiff requested access to the health records concerning the nail extraction performed on his incapacitated father. The plaintiff was not the possessor of the health information, and thus, upon the legal rules described hereinabove, had to demonstrate a relevant interest in obtaining the health records. The Court determined that the plaintiff's interest was justified. ${ }^{73}$ The Court also noted that the initial purpose for examining the health records, meaning the reason for the "relevant interest", was to decide whether the hospital could be blamed for malpractice. According to the court, the son had a right to sue the hospital for malpractice, as his father would have had; moreover, the son is apparently not a random conjectural third party, and the Court agreed that the son had a justifiable cause to access his father's health records. The Court dismissed the hospital's appeal. ${ }^{74}$

Contemporary Portuguese case law also includes a judgment concerning access to medical records provided to third parties who are not relatives of a certain patient. The case of Companhia de Seguros de Vida S.A. contre USF-Alma Mater (the officially reported names of the parties to the proceedings) was an appeal against the decision of TAF Sintra (Tribunal Administrativo e Fiscal), which dismissed a subpoena request from $S$. to produce the medical file of a patient, one Manuel, who was deceased by the time of the action. these files were being held by the defendant, the Regional Health Administration of Lisbon and Vale do Tejo. The plaintiff, an insurance company, had insured Manuel in February 2006. It was claimed that at the time, Manuel signed a waiver, upon which the insurance policy coverages excluded professional ailments or workplace

\footnotetext{
${ }^{72}$ Ibid, Sec. III, 3

${ }^{73}$ Ibid, Sec. III, 4.

${ }^{74}$ Ibid, Sec. III, 5-6.
} 
accidents. $^{75}$ The insurance contract (which is quite clear) contained a clause stipulating that the policy payment will be paid only once a series of supporting documents were produced. In the case of death, this included the following documents: the death certificate, a medical certificate stating the cause of death, a copy of an autopsy report and a number of additional documents, detailed in the insurance policy. ${ }^{76}$ Manuel died shortly before 2018 (the court report does not specify the precise date of his death and its cause, but it was seemingly a progressive disease). On February 22, 2018, the plaintiff company sent a letter of request to the Health Administration to obtain the insured's medical file, or alternatively, an updated list of his ailments and the dates of diagnoses. The plaintiff attached a copy of the health declaration signed by Manuel in 2006. The board did not comply with the request, in fact, they did not even respond. ${ }^{77}$ The plaintiff then filed a complaint with CADA (the Commission on Access to Administrative Documents) under Art. 16 of the LADA-2016, claiming that Manuel had previously authorised the insurance company to access his medical records, and indicated a medical advisor to whom the documents were expected to be sent. $^{78}$

Despite the fact that CADA found in favour of the plaintiff, ${ }^{79}$ the plaintiff still did not receive the medical file. ${ }^{80}$ The plaintiff then applied to the court to obtain the necessary documents. The trial court dismissed the claim, on the basis that a) the plaintiff did not possess an explicit (meaning written) authorisation to access the deceased man's health data (though in fact, the CADA assumed that the deceased had previously provided his explicit authorisation to give access to all necessary health data to the insurer via a medical adviser) and b) the plaintiff did not demonstrate a "constitutionally protected interest" in accessing the health records as a third party. ${ }^{81}$ The plaintiff impugned the said judgment to the administrative court of appeal, holding that the insurance company had a legitimate interest in obtaining the Manuel's medical file, which was required to assess whether the company was obliged to pay the sum covered in the policy. The plaintiff also claimed that upon the provisions of the insurance policy, the (now deceased) insured man had expressly authorised the company to access his medical records. ${ }^{82}$ Thus, the insurance company claimed that it had a "direct, personal and legitimate interest" in obtaining the necessary (though not all) medical records. The appellate court found that the assumptions upon which the

\footnotetext{
${ }^{75}$ Companhia de Seguros de Vida S.A. contre USF-Alma Mater (Administracao Regional de Saude de Lisboa e Vale do Tejo, IP), Acordao do Tribunal Central Administrativo Sul de 06.06.2019, Processo 1264/18.9BESN, Sec. II, A-B.

${ }^{76}$ Ibid, Sec. II, D.

${ }^{77}$ Ibid, Sec. I, 5-7; Sec. II.1.I, Sec. E-G.

${ }^{78}$ Ibid, Sec. II.1. I, 1-2.

${ }^{79}$ CADA, Pacerer No. 441/2018 (Opinion No. 441/2018).

${ }^{80}$ Companhia de Seguros de Vida S.A. contre USF-Alma Mater (Administracao Regional de Saude de Lisboa e Vale do Tejo, IP), Acordao do Tribunal Central Administrativo Sul de 06.06.2019, Processo 1264/18.9BESN, Sec. II.1.II; Sec. I, 1-7.

${ }^{81} \mathrm{I}$ bid, Sec. I, 10.

${ }^{82}$ Ibid, Sec. II, 2.
} 
Portuguese law permits third party access to medical records were fulfilled by the plaintiff. ${ }^{83}$ Thus, the Court affirmed the following:

9) The ownership of health information, involving clinical data, examinations, the results of analyses, interventions and diagnoses (as personal data) belongs to the person to whom it relates upon Art. 3 (1) of Lei No. 12/ 2005;

10) The insured person's declaration constitutes authorisation to health data access under the existing legislation;

Therefore, the Court decided to grant the appeal and summon the defendant to produce the requested medical records. ${ }^{84}$

A late 2019 decision by the Porto Court of Appeals dealt with the scope of the right to access medical files and restrictions pertaining to this right. It seems that the legislative provisions did not provide precise exemptions, so the court had to elaborate them itself. In this case $(B$. contre $C$. according to the original court report), the plaintiff applied to the court for a judgment to compel a dental clinic to give him the medical records relating his dental treatment as well as records manufactured within his examinations. Some time ago, the plaintiff had contracted an unnamed dental clinic for dental treatments, consultations and examinations. At some point, the plaintiff was strongly dissatisfied with the services of the clinic, and attempted to find an alternate clinic in order to finish the prescribed course of treatment and undo the damage to his health caused, as he alleged, by negligent treatment provided by the first clinic. The defendant, the dental clinic, refused to give the plaintiff his entire set of medical records, though they did hand over copies of several of them. In its judgment, the Court tried to clarify what is and what is not included within the scope of access to medical records, since the legislation did not provide any exact boundaries. ${ }^{85}$ The Court confirmed that upon art. 3 of Lei No. 12/2005, the health information is the property of the patient, while the hospitals are the repositories of the information, and may not dispose of it in any way other than for healthcare and other activities prescribed by law (Art. 5 of the same law). The Portuguese law, as the Court added, establishes a statutory right to access to medical records (Art. 3 (2) of the same law; Regulation 14/2009 DR 2nd ser. No. 8, 13.01.2009, art. 100 of the Code of Medical Ethics, and Art. 5 (3) of Lei No. 15/2014). Thus, as the Court affirmed, patients have property rights to their medical records (art. 3 of Law 12/2005), and upon the position of the Porto Court of Appeals, people whose respective medical records are kept in hospitals, do not have to use an intermediary to receive their files, or even justify their need for access. ${ }^{86}$

At the same time, it's unclear whether all the existing medical files should be disclosed - e.g. what is the appropriate policy regarding the doctors' private notes

\footnotetext{
${ }^{83} \mathrm{Ibid}$, Sec. II, 2.

${ }^{84}$ Ibid, Sec. III, i; Sec. III / Sec. III, iii; Sec. IV.

${ }^{85}$ B c. C., Acordao do Tribunal da Relacao do Porto, 08.09.2019, Processo No. 2147/18.T8AGD.P1, Sec. II.

${ }^{86} \mathrm{Ibid}$, Sec. II.
} 
concerning the health of the patient? The Court suggested that it would be wise to separate these notes from the clinical records and stated that there must be several types of exemptions allowing access to medical records to be limited. These include:

- A "therapeutic privilege", that is, the facts, if known by the patient, may endanger their life or health;

- Personal notes from the doctor, such as comments on the patient's behaviour (these are the doctors' intellectual property);

- Medical records of health information concerning third parties, if such are contained;

- Medical records provided by third parties (family members, spouses etc).

Upon this corollary, in the case described above the Court decided to grant the plaintiff access only to part of his medical records. ${ }^{87}$

\section{Conclusions}

The patient's right to access their personal medical records, as has been discussed above, derives from the contractual relationship between them and the physician or hospital, and from the patient's right to self-determination, which is acknowledged in the case-law and legislation of various countries worldwide. However, this right is negated by issues of medical confidentiality and the rules of hospital record-keeping, and thus courts are frequently requested to find a suitable balance between the interests at stake. Since the patient's interest in these records is often dictated by the information required for future litigation, one cannot claim that the access to medical records is a somewhat useless right, which may be exercised for diligence or mere curiosity and encroaches upon the hospital recordkeeping practices. As discussed above, some countries chose to adopt appropriate legislation to regulate the issue of access to medical records, while others chose to let it be decided by the Courts, which later elaborated a substantial amount of the principles regarding the scope of access, the rights of the third parties for inspection, the necessity of justifying it, the proprietary status of the medical records and the exemptions or restrictions for access to patients' medical data. Apart from Portuguese case law, the paper observes two models of accessing the health records - the one adopted in England, which is more restricted, and the one in Germany, which is far more liberal.

The Portuguese model is based upon statutory law, but the principles proscribed in the legislation are expounded by the Courts in their respective caselaw, which is the core of the paper. For instance, the Portuguese courts have firmly elaborated the principles upon which a third party may be given the right to access to medical records (whether an insurance company or a relative of an incapacitated patient, who is unable to give their consent or objection), as well as the possible exemptions from the right of access to medical records, which are not mentioned

${ }^{87}$ Ibid, Sec. II. 
in the national legislation. The Portuguese courts have also affirmed the legislative provisions concerning the proprietary rights in patient's medical records, and clarified the issues deriving from them. In fact, cases regarding access to a third party's medical records can seldom be found in the judgments of courts, but the young Portuguese jurisprudence possesses fresh judgments on granting access to patients' files. The current experience of the European Court of Human Rights in this matter is relatively small, but the manner in which the subject is treated in different European countries promises to provide the basis for ECtHR case law (and probably, the future EU legislation). In one of my recent papers, I discussed how the judgments of the German courts may be useful for the jurisprudence of the European Court of Human Rights ${ }^{88}$ in its future cases. The Portuguese model, being substantially younger than the German or English models, has quite a lot of positive features, embracing both legislation and case law, and the principles elaborated by Portuguese judges may also be helpful for the future jurisprudence of national and international human rights Courts.

\section{References}

Feenan, D. (1996). 'Common law access to medical records' in Mod. L. Rev. 59(1): 101 110.

Gründling, J.N. (2011). 'Die Dokumentationspflicht und das Einsichtsrecht des Patienten in die Krankengeschichte' (dissertation) University of Wien, Faculty of Law.

Kenna, T.W. (1973). 'The Patient-Physician Relationship: Present Law and Trends for the Future Implied in Cobbs v. Grant (Comment)' in U.S.S.F.L. Rev. 8:320-342.

Lytvynenko, A.A. (2019). 'Common Law Right to Access to Medical Records: The Commonwealth and European Court of Human Rights Practice' Materials of $7^{\text {th }}$ International Conference of $\mathrm{PhD}$ students and Young Researchers in Law 2.0: New Methods, New Laws, 25-26 April 2019, Vilnius, Lithuania, pp. 196-206.

Lytvynenko, A.A. (2020). 'A Right of Access to Medical Records: The Contemporary Case Law of the European Court of Human Rights and the Jurisprudence of Germany' in Athens Journal of Law 6(1):103 -122.

Lytvynenko, A.A. (2020a). 'Data privacy in the sphere of medical confidentiality: the historical and contemporary case-law of the United States, the European Court of Human Rights and selected Continental Europe states', in Topical Problems of State and Law 83:100-135.

\section{Cases}

\section{Austria}

OGH, 23.5.1984, 1 Ob 550/84.

\section{Belgium}

Bessems c. Le Ministere Public, Cass. 20 juillet 1855, Pas. 1855 I 303.

Bernardine de Neef c. Camille Moreau et Consorts, Cour d'Appel de Bruxelles, 24 mars 1905, BJ 1905.530.

Min. Publ.c. Seutin, Cour d'Appel de Bruxelles, 25 mai 1845, Pas. 1845 II 307.

\footnotetext{
${ }^{88}$ Lytvynenko (2020) at 118-119.
} 


\section{Canada}

Lavere v Smith's Falls Public Hospital, 26 D.L.R. 346 (1915).

\section{$\underline{\text { United Kingdom }}$}

\section{England}

Dunning v United Liverpool Hospitals' Board of Governors, [1973] 1W.L.R. 586.

Deistung v South West Metropolitan Regional Hospital Board, [1974] 1 W.L.R. 213.

Davidson v Lloyd Aircraft Services Ltd., [1974] 1 W.L.R. 1042.

McIvor v. Southern Health \& Social Service Board, [1978] 1 W.L.R. 757.

Church of Scientology v DHSS, [1979] 1 W.L.R. 723.

Gaskin v. Liverpool City Council, [1980] 1 W.L.R. 1549, 1553-1555 [1979 G. 2754].

Ex parte Martin, [1995] 1 W.L.R. 110, 117-119.

\section{Scotland}

Boyle v. Glasgow Royal Infirmary and Associated Hospitals, 1969 S.C. 72, 81-83 (Court of Sessions, Nov. 22, 1968).

Glacken v. National Coal Board, 1951 S.C. 82, 83-84 (Court of Sessions, Nov. 21, 1950).

\section{France}

Min. Publ. c. Doumayrou, Cour de Cass., Cham. crim., 6 Mai. 1836, Dall. Per. 1837 I 246. Carron c. Vallaton, Cour d'Appel de Lyon, 24 Mars. 1876, Sirey 1877 II 200.

Bousquet c. Compaigne le Gresham, Cour de Cass., Cham civ., 1 Mai 1899, Dall. Per. 1899 I 585.

Beltzer c. Hospices de la ville d'Auxonne, Cour d'Appel Dijon, 18 mars 1903, Sirey 1906 II 17.

Bresson c. Min. Publ., Cour de Cass., Cham. Crim., 30 Avr. 1909, Dall. Per. 1911 I 369.

G. c. R., Cour d'Appel de Lyon, 16 juin 1909, Dall. Per. 1910 II 123.

Cons. Aubertin c. V. Perrin, Trib. de Bar-Le-Duc, 15 Oct. 1913, Sirey 1914 II 13.

\section{Germany}

AG Essen, 21.04.1997 - 12 C13/97.

AG Weltzar, 15.08.1978-3C 707/78.

$B G H, 23.11 .1982$; VI ZR 222/79.

$B G H, 31.05 .1983$ - VI ZR 259/81.

$B G H, 02.10 .1984$ - VI ZR 311/82.

BGH, 06.12.1988 - VI ZR 76/88 .

LG Gottingen, 16.11.1978-2 O 152/78.

OLG Bremen, 31.07.1979 - 1 U 47/79.

OLG Köln, 12.11.1981: 7U96/81.

OLG Dïsseldorf, 29.03.2000, Az.:3 Wx 436/99.

OLG Munchen, 19.04.2001 - 1 U 6107/00.

OLG Karlsruhe, 16.08.2017 - 7 U 202/16.

$R G$ (Reichsgericht), 27.05.1908 - Rep. VI 484/07.

\section{Italy}

F.M. contro Casa di Cura Polispecialistica (...) e M.I., Consiglio di Stato, Sezione V., sentenza 28 settembre 2010, no. 7166. 
Vol. 6, No. 3 Lytvynenko: A Right to Access to Medical Records in the Case Law...

Netherlands, The

Hoge Raad, 20 April 2001, NJ 2001, 600; No. C99/030 HR.

Rechtbank Arnhem, 8 August 2005, Prg. 2005, 195, No. 128531.

\section{Portugal}

Acordao do Tribunal Relacao do Porto, 10.03.2008, Processo No. 0850591.

B c. $C$., Acordao do Tribunal da Relacao do Porto, 08.09.2019, Processo No. 2147/18.T8 AGD.P1.

Bernardo ... c. Santa Casa da Misericordia de Lisboa, Acordao do Tribunal Central Administrativo, 31.01.2018, Processo 353/17.BESNT.

Companhia de Seguros de Vida S.A. contre USF-Alma Mater (Administracao Regional de Saude de Lisboa e Vale do Tejo, IP), Acordao do Tribunal Central Administrativo Sul de 06.06.2019, Processo 1264/18.9BESN.

Unidade de Saude A c. B..., Acordao do Supremo Tribunal Administrativo, 08.08.2018, Processo 0394/18.

\section{Sweden}

Socialnämnden i Danderyds kommun, Kammratt Stockholm, 17 Sep. 2014, fall 5348-14 (2014).

\section{Switzerland}

H. c. M. et V., Arret de la Ire Section civile du 25 octobre 1918, BGE 44 I 322.

Meister c. B., Trib. Federal Suisse, 9 decembre 1892, Sirey 1893 IV 16.

\section{United States of America}

Agnew v. Parks, 172 Cal. App. 2d 756 (1959).

Oliver v. Harborview Medical Center, 94 Wash.2d 559 (1980).

Pyramid Life Insurance Co. v. Masonic Hospital Assn. of Payne County 191 F. Supp. 51 (W.D. Okla. 1961).

\section{European Civil Service Tribunal (International Court, defunct)}

V. v. European Parliament, Case F-46/09, Judgment of 5 July 2011.

\section{European Court of Human Rights (International Court)}

Gaskin v. United Kingdom, [1990] 1 FLR 167, App. No. 10454/83, Judgment of 7 July 1989.

K. H. \& Others v. Slovakia, App. no. 32881/04, Judgment of 28 March 2009.

M. G. v United Kingdom, [2002] F.C.R. 289, App. No. 39393/98, Judgment of 24 September 2002.

\section{European Court of Justice (International Court)}

Alessandro Moli v. Commission of European Communities, Judgment of 27 October 1977, Case No. 121/76 [1977] ECR 1971.

Emma Mollet v. Commission of European Communities, Judgment of 13 April 1978, Case No. 75/77, [1978] ECR 897.

Miss M. v. European Commission, Judgment of 10 June 1980, Case No. 155/78 [1980] ECR 1798. 


\title{
The Facelessness of Evil: Towards a Rationale for Corporate Criminal Liability
}

\author{
By Clément Labi ${ }^{*} \&$ Willy Tadjudje
}

\begin{abstract}
Why do we assign ethical intentions or mechanisms to certain businesses, which by design do not possess intentionality in the same way as actual businesspeople do? Are these merely opportunistic shortcuts from the judges or the law, in search of sizeable assets to implement reparation or levy a fine? On the contrary, the article will attempt to describe how the unethical aspect of some decisions could not be satisfactorily explained in terms of the intentions of individuals, but rather as being the products of the value system, or corporate culture, proper to the legal entity itself notably because the sense of individual responsibility is diluted and scruples assuaged. Therefore, not only can businesses in themselves can be assessed in terms of ethics, but the reality of a literally faceless business is congruent to institutionalised wrongdoing.
\end{abstract}

Keywords: Ethics; Criminal Law; Criminal Liability; Legal Personality.

\section{Legal Persons and the Riddle of Responsibility}

Our first notions of legal responsibility rely on the individual. One is supposed to assume the damages caused to third parties. Complexification of activity and life has hastened the evolution of the concept.

Usually, responsibility is either civil or criminal. In any case, the responsibility relies on the individual, but in criminal matters, there is exceptional consideration for intention.

The classical notion of legal responsibility tries to approximate moral responsibility mostly conceptualised in terms of individual morals. French law underlines the notion of "responsabilité du fait personnel - personal liability", to characterise this aspect. Indeed, since the reform of the Law of Obligations which came into effect on $1^{\text {st }}$ October 2016, the former article 1382 of the Civil Code, which became article 1240, lays down the principle of personal liability:

"Any act of man [human being or person], which causes damage to another person, obliges the person through whose fault it occurred to make reparation for it."

In other words, when the fault of a person causes damage to any victim, the person responsible must compensate the victim.

\footnotetext{
* PhD Candidate, Faculty of Law, Economics and Finance, University of Luxembourg, Esch-surAlzette, Luxembourg. Corresponding author. Email: clementlabi@gmail.com. ${ }^{ \pm} \mathrm{PhD}$ (Law), Lecturer, Faculty of Law, Economics and Finance, University of Luxembourg, Eschsur-Alzette, Luxembourg, Email: willytadj@gmail.com.
} 
The cause of liability may be multiple, but in general, the element that attracts attention is that of wrong ${ }^{1}$. Anyway, three conditions are necessary to engage personal liability under French law:

a) A wrong: such a person did not behave as a "bon père de famille/good father": he/she did not act as a normally prudent and diligent person would have done in the same circumstances.

b) Damage (material and/or moral).

c) A causal link between the wrong and the damage: there would have been no damage if the wrong had not been committed.

If these three conditions are met, the wrongdoers must repair for the harm he they caused to others by their behaviour.

The mere fact of being the victim of damage is therefore not sufficient to obtain compensation: such damage may in fact result from an unfortunate combination of circumstances, without anyone having committed the slightest wrong.

Mostly in criminal law, responsibility is very intensively linked to the notion of intention. Under French law, criminal responsibility implies the three constituent elements: a text of incrimination (legal element), a conduct sanctioned by the text (material element) and the involvement of the perpetrator in the commission of the conduct punished (intentional element) ${ }^{2}$.

The criminal infraction is that deed committed with criminal intent. Therefore, in most jurisdictions, the action committed under duress, or in a state of abolition of consciousness, is not criminal. These motives of exculpations are less powerful in non-criminal matters.

However, even in criminal law, arrangements are being found when intention is lacking. At that point, three examples will be given as illustrations.

In the United States, the Supreme Court would demand proof of mens rea when a criminal infraction is alleged. However, the requirement would not follow if the rule being violated was deemed to be "regulatory" in nature ${ }^{3}$. The Court stated that no evidence of mens rea was needed since the law at stake was "a regulatory measure in the interest of the public safety, which [could] well be premised on the theory that one would hardly be surprised to learn that possession of hand grenades is not an innocent act. ${ }^{4}$, evidently establishing a confusion between the requirement for a criminal intent and the principle that ignorance of the law should not be exculpatory.

\footnotetext{
${ }^{1}$ Namely the breach of duty (individuals owe duties to each another, when breached, they need to restore the status quo by means of reparation), the freedom or liberty (individuals are granted liberty or their liberty is acknowledged. But liberty also means that they should be held responsible for their actions), the wrong (similar to breach of duty but with a more pronounced moral aspect), the authority or custody, the command, etc.

${ }^{2}$ Bouloc (2019).

${ }^{3}$ Cass (1976).

${ }^{4}$ United States v. Freed, 401 U.S. 601 (1971).
} 
Similarly, French law used to state that there could be no criminal intention where there existed an "invincible error as to the Law". A corporation planned a transaction and asked the Ministry of Economy for an advice on whether this could be considered a violation of the anti-trust provisions of the Criminal Code: they were informed that it would not. However, the Court still convicted the company on the grounds that the company had the means to consult with a "quality lawyers" who should advise that the Ministry's advice was erroneous 6 .

Furthermore, alcohol diminishes discernment, sometimes to the point of abolition of consciousness: however, the law generally requires that the intoxicated state should not be "self-induced", which should not be a criterion as to the intent of the accused, and is in practice almost never met ${ }^{7}$.

The intentional element is therefore not verified in all cases. In the first example, the company arranged to seek information from the Ministry, but obtained bad advice that caused harm to others (an anti-trust violation).

Similarly, the notion of individual responsibility tries to move closer to moral responsibility. If one has harmed another by using means that may aggravate the commission of the offence, it is right that the punishment should be corresponding.

Consequently, it appears very clearly that even in criminal law, the intentionality requirement is not always scrupulously respected. For the time being, we should content ourselves with the proposal that criminal responsibility of legal persons is not a more "artificial" or "opportunistic" concept than civil liability applied to the same entities. In some sense, furthermore, repressive systems have themselves toyed with the Aristotelian concept of penal retribution for quite a long time. If, as it is classically proposed, criminal intent is quintessential to the offense itself, how would it be justifiable that an altered state of consciousness does not at the very least diminish the extent of the punishment? How could one account for the over-representation of the mentally ill in the prison population $^{8}$ ?

Therefore, one could either keep the definition of a crime on the metaphysical plane, and accept the dreadful consequences of retaining intention as an authentic criterion, or (and this is the only intellectually defensible alternative) consider that criminal had a function, and maybe implicitly accept that any principles are therefore pre-empted by the purposes, whether they be those stated by Lombroso ${ }^{9}$ or by Foucault ${ }^{10}$. At any rate, the same set of criteria could not explain the simultaneous existence of the infractions of manslaughter and murder.

The Industrial Revolution has provoked a revolution of its own as it shattered, in many instances, the individual and intentional stall marks of legal responsibilities, thus provoking an intellectual crisis which goes as deep as our very conception of what our ethical duties consist in.

\footnotetext{
${ }^{5}$ Article $122-3$ of the French Criminal Code.

${ }^{6}$ Cass. Crim. 19/03/1997.

${ }^{7}$ Herald (1970).

${ }^{8}$ Bechler (1988).

${ }^{9}$ Lombroso (1911).

${ }^{10}$ Foucault (1975).
} 
Analysis of tort law in three systems from the antiquity seems to reveal a discrete agreement that responsibility is based on the breach of the duty of man. In Jewish law", the principle is promulgated in the Talmud as "I am liable for the acts of anything which I am under a duty to guard". In English law, the four principal elements of negligence are: a duty of care, breach of that duty, a breach causing harm, and said harm being not too remote, as a consequence of the breach $^{12}$. French law also requires the simultaneous existence of a faute (which came to be defined very quickly in literature and by the courts as the objective breach of a legal obligation), damage, and a causality between the two ${ }^{13}$. Imperceptibly, however, these legal systems took with the extent to which a violation of duty was required to characterise responsibility. An excellent example is provided by the evolution of French Case-law on strict liability in case of "responsabilité du fait des choses" (damages caused by things instead of by a "personal fact"). Let us start with a textual comparison of the relevant provision of the Napoleonic Code as they were originally enacted.

Article 1382 provided that:

"Any deed whatever of man that causes damage to another, obliges him by whose fault it occurred to repair it."

This is complemented by Article 1383:

"One is responsible not only for the damage occasioned by our own act, but also by our own negligence or imprudence."

When providing for the legal regime of the damages caused by things

"One is responsible not only for the damage caused by their own act, but also for that which is caused by the acts of persons for whom they are responsible, or by things that are in their custody."

It is therefore obvious that Article 1384 only continues the principle of Article 1382. However, starting in the $19^{\text {th }}$ century, French-case-law rediscovered Article 1384 as a source of responsibility with no requirement of a faute ${ }^{14}$, which literature correctly construes as a response to the growing issue of workplace incidents, and as a cornerstone of the early building of the French welfare State ${ }^{15}$.

\section{The Responsibility of the Legal Entity}

Perhaps the second-most difficult concept to comprehend is the one of the responsibility of the legal entity.

\footnotetext{
${ }^{11}$ Lieberman (1927).

${ }^{12}$ Deakin, Johnson \& Markesinis (2003).

${ }^{13}$ Terré, Simler, Lequette \& Chénedé (2018).

${ }^{14}$ Ibid.

${ }^{15}$ Ewald (2020).
} 
Professor Talbot, whose expertise is in UK company law, traces back the concept of corporate liability to, paradoxically, that of limited liability of the shareholders. The point she makes can be summarised as follows: case-law started by recognizing that shareholders were only liable for the investment they had actually made in the company. Therefore, creditors would not have had any chance to recover their receivables, if not through the acknowledgment (or invention) of full legal personality of the corporation itself, thus allowing for the identification of corporate assets that could be seized. ${ }^{16}$ In parallel, the same intellectual movement led to the understanding that companies could bear liabilities the same way that natural persons do.

There are of course excellent practical reasons why this should be, and the existence of corporate liabilities are desirable for even their members. For instance, when granting a large-scale loan, a bank would much rather have a corporation be the borrower than dealing directly with the investors (insofar as, in most cases, the bank offers more solid assets and future cash flows) said investors would of course much rather have "their" corporation assume the liabilities, lest the very principle of limited liability loses entirely this meaning. ${ }^{17}$ However, even this modest arrangement is actually quite difficult to justify from a theoretical standpoint: if the corporation does indeed possess full legal personality, how could it incur responsibility either for agreements signed by officers or for torts caused to third parties? The unifying concept of representation does not here serve as a panacea, as some limit cases show to evidence: for instance, some actions taken by the future directors before the incorporation of the company can be transformed into the company's own after the company is set up; on the contrary, statutory limitations to the power of the directors cannot, classically, be opposed to third parties acting in good faith. For the sake of clarity, we are obviously not arguing here that directors should not be able to generate responsibilities for the company they represent, however we do argue that the concept is not devoid of problematics, if only because, while natural persons might appoint an agent to take action in their name and on their behalf, the agents of the company are in actuality appointed not by itself but by its shareholders, or in some cases, even by its already appointed directors ${ }^{18}$ (creating a recursive logic issue that, to the best of our knowledge, has not been satisfactorily resolved).

\section{The Rationale for Criminal Responsibility of the same Legal Entity}

The most difficult question altogether is the rationale for criminal responsibility of the same legal entity. We saw earlier how most legal systems dissociated civil responsibility and intent, for instance associating it with risk and sometimes with the idea of guarantee. Nevertheless, the same legal systems demand, in principle, that intentionally be characterised whenever finding a person guilty of committing a criminal offence.

\footnotetext{
${ }^{16}$ Talbot (2015).

${ }^{17}$ Merle (2020).

${ }^{18}$ Davies, Hopt, Nowak \& van Solinge (2013).
} 
Hence, the relatively recent invention of the criminal responsibility of legal persons can be justified by a teleological approach, but remains challenging from the point of view of the principles. Few even attempt to explain it by reasons other than mere opportunism. Among those few, Clarkson, sketching the outline of what corporate mens rea, writes the following ${ }^{19}$ :

"companies can be conceived as culpability-bearing agents who 'act' through their offices and employees and whose 'mens rea' is to be found in their corporate practices or policies [...] both recklessness or intention can also be found in a company's policies, operational procedures and lack of precautions. If the corporate culture permitted or encouraged the wrongdoing, it may be easy to infer that the corporate body itself must have foreseen the possibility of the harm occurring [...] or that it has created an obvious and serious risk of the wrong resulting [...] or that the consequences was virtually certain to occur from which intention may be inferred. The important point about this approach is that it is not whether any individual within the company would have realised or foreseen the harm occurring but whether in a properly structured and organised careful company the risks would have been obvious."

Our intent is not to nit-pick a theory that tries to grasp with such an elusive concept, but we fear that there might somewhat of a petitio principis in the acceptance that companies literally act although the author uses quotation marks) through offices and employees; the policies can reflect mens rea and essentially the corporate body is identified with the company itself.

However, it does make an excellent point about corporate culture which will serve as the basis of our own proposal, as further detailed below.

It is thus no surprise that the opinion of the Supreme Court of the United States validating the concept of corporate criminal liability should be so disappointing. Predictably, after recalling that a company can be responsible for the actions of its employees and other agents, Justice Day very succinctly and unconvincingly uses opportunity as an explanation:

"It is true that there are some crimes which, in their nature, cannot be committed by corporations. But there is a large class of offenses, of which rebating under the federal statutes is one, wherein the crime consists in purposely doing the things prohibited by statute. In that class of crimes, we see no good reason why corporations may not be held responsible for and charged with the knowledge and purposes of their agents, acting within the authority conferred upon them. [...] If it were not so, many offenses might go unpunished and acts be committed in violation of law where, as in the present case, the statute requires all persons, corporate or private, to refrain from certain practices, forbidden in the interest of public policy" ${ }^{20}$ (emphasis ours).

This is uttered after sweeping under the rug Blackstone's advice that "A corporation cannot commit treason, or felony, or other crime in its corporate

\footnotetext{
${ }^{19}$ Clarkson (1988).

${ }^{20}$ New York Central \& Hudson River Railroad Co. v. U.S, 22 Ill.212 U.S. 481, 29 S. Ct. 304, 53 L. Ed. 613 (1909). Emphasis ours.
} 
capacity, though its members may, in their distinct individual capacities"21 and quoting approvingly the clearly tautological argument, contained in Bishop's New Criminal Law, and according to which:

"Since a corporation acts by its officers and agents, their purposes, motives, and intent are just as much those of the corporation as are the things done. If, for example, the invisible, intangible essence or air which we term a corporation can level mountains, fill up valleys, lay down iron tracks, and run railroad cars on them, it can intend to do it, and can act therein as well viciously as virtuously. ${ }^{22,}$

\section{Are Legal Persons only Responsible by Default?}

A legal person acts through individuals and that is the reason why they are only responsible by default. In liability law, in addition to personal liability, which is the most classic, there is also vicarious liability. The latter has several facets, including, in French law, the liability of principals for the acts of employees (responsabilité des commettants du fait des préposés). It is this aspect that is most closely related to liability in corporate law. In reality, even the so-called unipersonal company, by virtue of its legal personality, is not comparable to an individual who may act intentionally.

However, in corporate law, we are witnessing an excessive extension of the scope of vicarious liability. In practise, boards purposefully dilute responsibilities. At any rate, the framework for the responsibility of legal persons needs more clarification collectivised crime needs organised irresponsibility.

For many reasons, strict vicarious criminal liability corporations appears at first sight unfair, at least because "it subjects a corporation to criminal liability when a single rogue employee engages in misconduct - even if the misconduct directly violates the corporation's policies and occurs despite a rigorous compliance program. As a result, a single errant employee can cause the downfall of a multi-national corporation and the loss of thousands of jobs" 23 .

We will here make a case on why the criminal responsibility of the corporation could be accepted as said corporation is an environment set in place so that individual responsibilities are erased.

Corporation law functions upon the principle of limited liability. ${ }^{24}$ This is obviously true for shareholders, whose exposure is generally limited to the amount of their investment in said corporations. "The no-obligation, no-responsibility, noliability nature of corporate shares permits their owners - or their institutional representatives - to enjoy income rights without needing to worry about how the dividends are generated. They are not legally responsible for corporate malfeasance and in the event of failure only their initial investments are at risk",25.

\footnotetext{
${ }^{21}$ Blackstone (1765).

${ }^{22}$ Bishop (1893).

${ }^{23}$ Ibid.

${ }^{24}$ Kraakman, Hansmann, Pargendler, Hertig, Kanda \& Davies (2004).

${ }^{25}$ Ireland (2010).
} 
However, directors pursue the same strategy: they seek eternally to diminish their responsibility, notably through the means of $\mathrm{D} \& \mathrm{O}$ insurance, but also by mixing their decisional power with those of the other directors and stakeholders in the company. No one likes risks for the sake of risk ${ }^{26}$.

Empirically, it is often a difficult task to find one or several persons who can in all honesty be held individually/jointly liable for the damages caused by/in the interest of/ in the name of the corporate structure. In fact, "courts generally hold that a corporation is subject to strict vicarious liability for a criminal act by one of its employees if the employee acted within the scope of his employment and intended, at least in part, to benefit the corporation"27. The concept of intention guides the analysis of the judge in this perspective. That is why "even if the corporation did not receive any financial benefit from an employee's crime, it will still be subject to strict vicarious criminal liability if the employee intended, in part, to benefit the corporation" 28 .

Oftentimes, the best reasoning judges can cling to be the failure of a director or officer to do something: by their inaction, they have caused a catastrophe. They literally did nothing - therefore falling to a bias according to which action is always better than a lack of action. Consequently, "the theory of strict vicarious criminal liability for corporations that has prevailed in the federal courts of appeals does not allow a corporation to defend itself by showing that the employee's conduct violated its compliance policy or a directive from a superior,"29.

Beyond boards, organisations in general tend to rely on this development of vicarious liability law. Despite the disadvantages that this may present, both morally and legally, organisations do not hesitate to find loopholes. Recognizing that liability will be attached to the group and not to the individual acting in the name and on behalf of the group, various mechanisms are being implemented to limit individual management and favour group actions. Three objectives are therefore planned: collectivisation, mitigation and dilution.

Many modern management concepts help those three objectives:

a) Transition from management by a trusted representative to management by a board, which is perhaps an innovation that was born with the Dutch East India Company in the $17^{\text {th }}$ century ${ }^{30}$ (and the very helpful rule of majority. However, directors sleep better with unanimity).

b) The concept, introduced by Peter Drucker, of management by objectives ${ }^{31}$. Executives must take actions to meet certain goals: therefore, every action can be justified by the importance of the "cause".

c) Shareholder democracy: asking the shareholders to absolve you by approving your actions (e.g. say-on-pay). This is not a very good deal for

\footnotetext{
${ }^{26}$ Plesch \& Blankenburg (2012),

${ }^{27}$ Greenberg \& Brotman (2014).

${ }^{28} \mathrm{Ibid}$.

${ }^{29}$ Ibid.

${ }^{30}$ Steensgaard (1982).

${ }^{31}$ Drucker (1954).
} 
them. They set executives so that they will not be needed to take every decision; they are interested in dividends, not politics. ${ }^{32}$

We further propose that the nature of corporate crime might makes it particularly to track down responsibility altogether, and maybe individual responsibility with further reason, for the very reason that the criminal system cannot follow an intention, but only the manifestation of an intention. Frustration has been expressed as to the small number of convictions actually issued in the wake of the 2007-2008 financial crises. One factor may be that although a very extensive set of rules existed even at the time, any executive worth its salt either knew these regulations very well, or could pay the right amount of money to obtain the right advice as to not to fall within the category that would trigger actual criminal responsibility and would necessarily require to be, simultaneously, strictly defined and construed according to the meta-rules of criminal law.

To illustrate this simple fact, let us provide a simple example: that of tax fraud. Taxation offers very straightforward incentives, as far as reward and punishment are concerned: the craft of the tax adviser is, first, to know what the exact rules of the game are; by careful examination of the tax code, the tax administration practice, the double tax treaties etc. and then to design a solution that would be as close to the criminal limit as possible. If then, the tax scheme is challenged by the judge, a certainly relevant defence would be to show the "homework" done in preparation of that fateful day, which fateful day any astute executive bears in a corner of his mind.

Another good example is offered by the narratives surrounding the brutal collapse of Lehman Brothers in 2008 after posting a record profit in 2007. The profit, it soon showed, was the proverbial castle built on sand, but the legal aspect was not so easy to shatter. The main chink in Lehman's armour was a scheme known as Repo 105: essentially, shortly before the end of each quarter (in other words, when the bank's results were due to be reported), Lehman Brothers would "sell" financial assets with the contractual provision that it would repurchase it, for a higher price, shortly after the quarter ended, which is of course tantamount to a loan from a financial standpoint; however, the aim of the bank was to qualify the repurchase agreement as a bona fide sale for accounting and reporting purposes ${ }^{33}$. Lehman's executives would not go with the scheme without securing a legal opinion, i.e. a letter issued by a renowned law firm opining as to the legality of the schemes, and, unsuccessfully in obtaining one from a law firm in the United States, they ended up with a legal opinion from the London branch of Linklaters LLC, thus acquiring a semblance of legality. When, furthermore, the position of the company had become so untenable that a sale appeared unavoidable the chief executive officer and public face of the company, Richard Fuld, publicly announced that he would refuse to sell it at too low of a price, then, in an equally vocal fashion, offered his resignation of his head were to be required as a sine qua non by prospective acquirers ${ }^{34}$. This of course begs the question: is it fairer to

\footnotetext{
${ }^{32}$ Cheffins \& Thomas (2001).

${ }^{33}$ Jeffers (2011).

${ }^{34}$ Fishman (2008).
} 
describe him as being ethical, keeping the best interest of his company above all, or as acting ethical, and being astute? As far as corporate crime is concerned, things always look simpler from afar.

There could be debate over whether individual members of boards of directors are more prone to irresponsible behaviour than the average. Estimations of psychopathic traits among executives necessarily involve some element of guesswork if only because voluntary subjection to an in-depth psychiatric evaluation would probably not be a popular idea among CEOs, furthermore, the lead article on the subject ${ }^{35}$ ends up with a wide range of estimation (between $4 \%$ and 20\%). However, Dutton notes a prevalence of psychopaths in civil service or among professions such as (unnervingly) lawyers. It is worth noting that legal scholars do not appear on Dutton's list.

We would above all emphasise that individual psychopathy of the leader of an organisation is not a shortcut to understand the deviant behaviour of the organisation itself. In 2014, the British government launched a programme aimed at recruiting psychopaths, because this population tends to present certain very desirable traits in terms of drive and organisation ${ }^{36}-$ it is even conceivable that ruthlessness, or extreme detachment from one's feelings may prove a very valuable trait in certain professions (which would likewise explain why Dutton ranks surgeons so highly on his list ${ }^{37}$ ). Another argument against the uniqueness of corporate board deviance would stem from the efficient-market hypothesis. Indeed, shareholders would eventually, if only by trial and error, avoid those executives whose criminal disposition would be excessive when compared to the benefits of ruthlessness, as the cost of civil suits and criminal fines would end up affecting the company's earnings. In general, it would be more logical for shareholders to prefer criminal fines imposed on the directors than on the company itself, and thus an interesting idea for further research would be to verify whether they, in actuality, favour those jurisdictions and company forms that effectively fit this criterion.

An even better example comes from the darker pages of history and from the dismal field of genocide studies. According to Dr Gregory Stanton, all genocides tend to follow the same pattern, the last element of which being denial - as a matter of fact, Stanton asserts that denial of genocide is a constant and that its continuation is a incontestable proof that genocidal activities are still occurring. However, the organisation of deniability starts much earlier in the process. According to Stanton himself, genocide is "often using militias to provide deniability of state responsibility" 38 . It has been observed that the very language used by the perpetrators is often intentionally vague and ambiguous, so as to make any future use of such language as evidence difficult. This tendency to euphemisation is noted by the seminal work on Third Reich phraseology, LTI Lingua Tertii Imperii by Victor Klemperer: for example, the otherwise abundant

\footnotetext{
${ }^{35}$ Brooks \& Fritzon (2016). The article was eventually retracted due to a plagiarism issue.

${ }^{36}$ Saul (2014).

${ }^{37}$ Dutton (2012).

${ }^{38}$ Stanton (1996).
} 
Nazi documentation evidencing the genocide of European Jews during the Second World War would use the following euphemisms

$(\text { Schleierwörter })^{39}$ :

Evakuierung (literally: "evacuation"): deportation

Konzentrationslager (lit.: "concentration camp"): extermination camp

Sonderbehandlung (lit.: "special treatment"): murder

Verschärfte Vernehmung (lit.:"intensified interrogation"): torture

As a matter of fact, the ubiquitousness of the "Special treatment" code word, instead of "murder", in Nazi documentation, was indeed used by Holocaust deniers after the war as a way negating the reality and magnitude of the crimes perpetrated by Germany ${ }^{40}$. Himmler was obsessive about the documentation of the Holocaust and imposed a further euphemisation: durchschleusen (literally, "to guide through"). Korherr had issued a report which Himmler praised for its discretion. However, he did receive the following observation:

"Der Reichsführer-SS hat Ihren statistischen Bericht über "Die Endlösung der europäischen Judenfrage" erhalten. Er wünscht, daß an keiner Stelle von "Sonderbehandlung der Juden" gesprochen wird. Auf Seite 9 muß es folgerndermaßen heißen:

"Transportierung von Juden aus den Ostprovinzen nach dem russichen Osten:

Es wurden durchgeschleust

durch die Lager im Generalgouvernement...

durch die Lager im Warthegau..."

Eine andere Formulierung darf nicht genommen werden...

[translation]:

"The Reichsführer-SS has received your report on "The Final Solution of the European Jewish Question". He wishes that "special treatment of the Jews" not be mentioned anywhere. On page 9, it must be formulated as follows:

"They were guided [through]

through the camps in the General Government

through the camps in the Warthegau

No other formulation is to be employed. ${ }^{41, "}$ (Emphasis ours in all cases)

One final, and very telling example, can be found not in a genocide per se but in an alleged violation of international law. On November 1979, against the backdrop of the Islamic Revolution and the backlash generated by the decision, made by the United States Government, to welcome the Shah on their territory (in addition to the general hostility boiling under the new regime), a group whose members described themselves as the "Muslim Student Followers of the Imam's Policy", and not acting on behalf of the Iranian State, famously assaulted the United States Embassy, and took hostages among the diplomatic personnel. Deliberating on the merits of the action later filed by the United States, the International Court of Justice, notes perplexingly:

\footnotetext{
${ }^{39}$ Klemperer (1947).

${ }^{40}$ Schermer \& Grobman (2009).

${ }^{41}$ Kogon \& Langbein (1995).
} 


\begin{abstract}
"No suggestion has been made that the militants, when they executed their attack on the Embassy, had any form of official status as recognized "agents" or organs of the Iranian State. Their conduct in mounting the attack, overrunning the Embassy and seizing its inmates as hostages cannot, therefore, be regarded as imputable to that State on that basis. Their conduct might be considered as itself directly imputable to the Iranian State only if it were established that, in fact, on the occasion in question the militants acted on behalf of the State, having been charged by some competent organ of the Iranian State to carry out a specific operation. The information before the Court does not, however, suffice to establish with the requisite certainty the existence at that time of such a link between the militants and any competent organ of the State. ${ }^{42,}$
\end{abstract}

Therefore, it would look like the corporate / political strategy of distancing oneself from the crime worked, but the International Court of Justice actually finds a solution that is in equal parts elegant and profound. Building notably on Articles 22 ("The receiving State is under a special duty to take all appropriate steps to protect the premises of the mission against any intrusion or damage and to prevent any disturbance of the peace of the mission or impairment of its dignity") and 29 of the 1961 Vienna Convention to conclude that the Iranian Government had a positive obligation to take any "appropriate steps" to remedy the violation of international law at work at the American Embassy, demonstrating how a responsibility of the legal person could be justifiably demonstrated ${ }^{43}$.

Drawing inspiration from those examples international law, an intellectually satisfying justification of how criminal liability can be imposed on legal persons, in particular corporation. To illustrate this, Apel and Paternoster sketch a theory of "criminogenic corporate culture": one view possesses almost Rousseauist accents: good, educated people are encouraged are driven to crime by the culture of the corporation, another related view relies on the concept of assortative mating: subjects with unethical traits are themselves attracted to companies that are equally unethical $^{44}$. In other words, the corporation's culture, disconnected to any of its officer in particular serves at least as an enabler, and at worst as an enticer of criminal behaviour. The same idea of using "corporate culture" as a cornerstone of corporate criminal liability is also defended, albeit slightly less convincingly, in a report prepared by Allens Arthur Robinson for the attention of the United Nations Special Representative of the Secretary-General on Human Rights and Business. ${ }^{45}$

Professor Kent Greenfield argues that since corporations are to a very large extent acknowledged as persons (under US Law), they should be treated exactly as $\operatorname{such}^{46}$. Such a simplification would seem both unappealing and impractical to us. But the group does bear a lot of responsibilities that the individuals refuse.

\footnotetext{
${ }^{42}$ International Court of Justice, Case Concerning United States Diplomatic And Consular Staff In Tehran, Judgment of 24 May 1980.

${ }^{43}$ Ibid.

${ }^{44}$ Apel \& Paternoster (2009).

${ }^{45}$ Robinson (2008).

${ }^{46}$ Greenfield (2018).
} 


\section{Conclusion}

Liability is first of all assumed individually, insofar as each person is supposed to provide reparation for the harm he or she has caused. However, persons acting in legal life are not only natural persons. Alongside the latter, there are also legal persons, even though they are constituted by natural persons. In absolute terms, the legal person is fictitious, since it is set up by natural persons who act in its name and on its behalf on a daily basis. Curiously, while personal liability is completely based on the individual, the law has made provisions to limit the liability of the shareholders to their contribution to the share capital. Such a configuration of the pattern of liability is problematic and may lead corporate directors to take unethical decisions: in fact, regardless of what the law states, they are very skilled at minimising their legal exposure. There is therefore a kind of systematic, organised and planned irresponsibility in corporate governance. Legislators should review the liability regime in legal persons, and even more so in corporations, notably by taking corporate culture seriously. Even in the corporate context, steps could be taken to ensure that those who act are subject to the legal regime of individual liability but because of the dynamics of corporate life, the task appears, unfortunately, Sisyphean.

\section{References}

Apel, R. \& R. Paternoster (2009). 'Understanding "Criminogenic" Corporate Culture: What White-Collar Crime Researchers Can Learn from Studies of the Adolescent Employment-Crime Relationship' in S.S. Simpson and D. Weisburd (eds.), The Criminology of White-Collar Crime. New York: Springer.

Bechler, J. (1988). 'Are jails replacing the mental health system for the homeless mentally ill?' in Community Mental Health Journal 27:1-78.

Bishop, J. (1893). Bishop's New Criminal Law. Chicago: T.H. Flood \& Co.

Blackstone, W. (1770). Commentaries on the Laws of England. Oxford: Clarendon Press.

Bouloc, P. (2019). Droit pénal général. Paris: Dalloz

Brooks, N. \& K. Frizton (2016). 'Psychopathic personality characteristics amongst high functioning populations' in Crime Psychology Review 2:22-44.

Cass, R. (1976). 'Ignorance of the Law: A Maxim Reexamined' in William \& Mary Law Journal 17:671-699.

Cheffins, B. \& R. Thomas (2001). 'Should Shareholders Have a Greater Say Over Executive Pay?: Learning from the US Experience' in Journal of Corporate Law Studies 1:277-315.

Clarkson, C.M.V. (1988). 'Corporate Culpability' in 2 Web Journal of Current Legal Issues. http://webjcli.ncl.ac.uk/1998/isue2/clarkson2.html

Davies, P., Hopt, K., Nowak, R. \& G. van Solinge (2013). Corporate Boards in Law and Practice: A Comparative Analysis in Europe. Oxford: Oxford University Press.

Deakin, S., Johnston, A. \& B. Markesinis (2012). Markesinis and Deakin's Tort Law. 7th ed. Oxford: Oxford University Press.

Drucker, P. (1954). The Practice of Management. New York: Harper.

Dutton, K. (2012). The Wisdom of Psychopaths: What Saints, Spies, and Serial Killers Can Teach Us about Success. Portsmouth: Heinemann. 
Ewald, F. (2020). The Birth of Solidarity: The History of the French Welfare State. Durham: Duke University Press.

Fishman, S. (2008). 'Burning Down His House' in New York Magazine, November 27. https://nymag.com/news/business/52603/

Foucault, M. (1975). Surveiller et punir. Paris: Gallimard.

Greenberg, J. \& E. Brotma (2014). 'Strict Vicarious Criminal Liability For Corporations and Corporate Executives: Stretching the Boundaries Of Criminalization' in American Law Review 51:79-98.

Greenfield, K. (2018). Corporations Are People Too (And They Should Act Like It). New Haven: Yale University Press.

Herald (1970). 'Criminal Law: Alcoholism as a Defense' in Marquette Law Review. 53:445-450.

Ireland, P. (2010). 'Limited liability, shareholder rights and the problem of corporate irresponsibility', in Cambridge Journal of Economics 34:837-856.

Jeffers, A. (2011). 'How Lehman Brothers Used Repo 105 to Manipulate Their Financial Statements', in Journal of Leadership, Accountability and Ethics 8:44-55.

Klemperer, V. (1947). LTI - Lingua Tertii Imperii: Notizbuch eines Philologen. Leipzig: Reclam Verlag.

Kogon, E. Langbein, H. \& A. Rückerl (1995). Nationalsozialistische Massentötungen durch Giftgas: eine Dokumentation. Frankfurt am Main: Fischer Taschenbuch Verlag.

Kraakman, R., Hansmann, H., Pargendler, M., Hertig, G., Kanda H., \& P. Davies (2004). The Anatomy of Corporate Law: A Comparative and Functional Approach. Oxford: Oxford University Press.

Lieberman, B. (1927) 'Torts in Jewish Law' in Journal of Comparative Legislation and International Law 9:231-240.

Lombroso, C. (1911). Crime - Its Causes and Remedies. Boston: Little, Brown and Company.

Merle, P. (2020). Droit commercial : les sociétés commerciales. 23rd ed. Paris: Dalloz.

Plesch, D. \& S. Blankenburg (2012). 'Corporate Rights and Responsibilities: Restoring Legal Accountabilitye' in SOAS Research. https://www.soas.ac.uk/cisd/research/ma terial/file120296.pdf

Robinson, A.A. (2008). 'Corporate Culture' as a Basis for the Criminal Liability of Corporations'. Report to the United Nations Special Representative of the SecretaryGeneral on Human Rights and Business.

Saul, H. (2014). 'UK Government officials considered recruiting psychopaths 'to keep order' after nuclear attack'. The Independent, November 1. https://www.indepen dent.co.uk/news/uk/home-news/uk-government-considered-recruiting-psychopathsto-keep-order-after-nuclear-attack-9832910.html

Schermer, M. \& A. Grobman (2009). Denying history: who says the Holocaust never happened and why do they say it? Berkeley: University of California Press.

Stanton, H. (1996) 'The 8 Stages of Genocide'. Working paper presented of the Yale Program on Genocide Studies.

Steensgaard, N. (1982). "The Dutch East India Company as an Institutional Innovation", in Maurice Aymard (ed.), Dutch Capitalism and World Capitalism / Capitalisme hollandais et capitalisme mondial (Studies in Modern Capitalism / Etudes sur le capitalisme moderne), 235-257. Cambridge: Cambridge University Press.

Talbot, L. (2015). Critical Company Law. 2nd ed. Abingdon-on-Thames: Taylor \& Francis.

Terré, F., Simler P., Lequette Y. \& F. Chenedé (2018) Droit Civil : Les obligations. 12th ed. Paris: Dalloz. 


\section{Cases}

France

Cour de cassation - Chambre criminelle - 19/03/1997.

$U S A$

New York Central \& Hudson River Railroad Co. v. U.S, 22 Ill.212 U.S. 481, 29 S. Ct. 304, 53 L. Ed. 613 (1909).

United States v. Freed, 401 U.S. 601 (1971).

International Court of Justice

Case Concerning United States Diplomatic and Consular Staff In Tehran, Judgment of 24 May 1980. 


\title{
All that Glitters is Not Always Gold or Silver: Typical Bilateral Investments Treaties (BITs) Clauses as Peril to Third World Economic Sovereignty
}

\author{
By George Forji Amin
}

\begin{abstract}
Modern BITs habitually begin with a preamble, whereupon basic concepts such as what constitutes an investment and an investor for the purpose of the treaty are somewhat defined. The effectiveness and manner in which BITs pursue their objectives are remarkably uniformed, thanks to their vigorous investors-friendly provisions (although they sometimes use slightly varied expressions), which are also highlighted at length. The most common provisions include National treatment (NT), Most Favoured Nation clause (MFN), Fair and Equitable Treatment (FET), and Disputes Settlement Mechanisms (DSM). These clauses together constitute the core of the treaty rights, thus, they end up affecting the general equilibrium of the treaties. The uniformity of the provisions is primarily due to model BITs by developed countries and standard BITs developed by International Organisations such as the OECD, both of which are a codification of longstanding disputed norms of customary international law.
\end{abstract}

Keywords: Bilateral Investment Treaties (BITs); Disputes Settlement Mechanisms (DSM Fair and Equitable Treatment (FET); National treatment (NT); Most Favoured Nation clause (MFN)

\section{Introduction}

The flight of capital from one country to another is nothing new. However, rules governing the entire regime of International Investment have expanded considerably since the end of the Second World War, thanks to Bilateral Investment Treaties (BITs) between home states of investors (Home State) and the state hosting the investment (Host State). ${ }^{1}$ The significance of this development is the stimulation of legal mechanisms to protect assets of investors in foreign countries. ${ }^{2}$

BITs must be understood within the context of the huge interest attached to the inflows of Foreign Direct Investments (FDI) by developing countries during the last three decades. These countries have essentially reached a broadening consensus that attracting FDI inflows would result to gross investments leading to economic growth and development. Given the competitive nature of FDI,

\footnotetext{
*Research Fellow and Adjunct Lecturer in International Law, Faculty of Law, University of Helsinki, Finland. E-mails: aminforji@gmail.com or amingeorges@ yahoo.co.uk or amin.forji@helsinki.fi. ${ }^{1}$ Hamilton \& Rochwerger (2005) at 2; Newcombe \& Paradell (2008) at 11.

${ }^{2}$ Hamilton \& Rochwerger (2005); Newcombe \& Paradell (2008) at 11.
} 
many of them have pinned their hopes on BITs as a means of bridging the wide development gap with the developed world. It is expected that a demonstrative commitment to investment protection would eventually improve their chances in the worldwide competition for foreign direct investment (FDI). ${ }^{3}$ Despite a modest start, BITs have emerged as universally accepted legal instruments for the promotion and protection of Foreign Investment. ${ }^{4}$

The first BIT was signed in 1959 between former West Germany and Pakistan. ${ }^{5}$ More BITs have been signed in the last fifteen years than the preceding three decades. ${ }^{6}$ The extent of their proliferation has been extraordinary, as has been their clauses, thus making them one of the most remarkable recent developments in contemporary international law. The United Nations Conference on Trade and Development (UNCTAD) has estimated that BITs reached a record number of 2608 in 2008, up from 2,495 in 2005, with over 1,891 entering into force. This number makes BITs the largest group of any kinds of treaties, past and present. ${ }^{7}$ This is remarkable given that only 75 BITs were signed in the 1960s. The number increased to 167 and 389 in the '70s and '80s respectively. ${ }^{8}$ In terms of countries, just 2 countries signed BITs in the 1950s. That number steadily increased to 48 in the 1960s, 69 in the 1970s, 102 in the 1980s and 173 by the end of the 1990s. ${ }^{9}$ At the same time, International Centre for Settlement of Investment Disputes (ICSID) registered 182 investment arbitrations between 1973 and $2007 .^{10}$

BITs clauses are largely pro-investor standards of treatment, with expressive promises, for instance that foreign investors would be treated fairly and equitably, in a non-discriminatory manner vis-à-vis the domestic investors, and/ or on a Most-Favoured nation basis, and most importantly that in the event of disputes, the investors would have a right to direct recourse against the host state. ${ }^{11}$ Consequently, it is not only the number of BITs that are on the rise, but the numbers of countries involved as well as a corresponding surge in investor-tostate disputes.

This paper seeks to demonstrate that despite the mad rush for BITs, they nonetheless come with baggage for host states. The agreements accord foreign investors the right to directly sue host states for alleged violations of any of the treaty's investment protection provisions, ${ }^{12}$ that is, a strong recognition of nonstate actors. The clause is considered to be the most economically important aspect of BITs. The ability of private parties who invest abroad to address a

\footnotetext{
${ }^{3}$ Busse, Königer \& Nunnenkamp (2010) at 147; Kurtz (2002) at 723.

${ }^{4}$ Robin (1984) at 931.

${ }^{5}$ The Treaty between the Federal Republic of Germany and Pakistan for the Promotion and Protection of Investments (Germany v. Pakistan (1959)), 457 U.N.T.S. 23.

${ }^{6}$ Vandevelde (1996) at 545.

${ }^{7}$ Greig, Annacker \& Zaide, (2008) at 257. See generally UNCTAD 2008.

${ }^{8}$ Neumayer \& Spess (2005) at 1569.

${ }^{9}$ Hamilton \& Rochwerger (2005) at 6.

${ }^{10}$ Convention on the Settlement of Investment Disputes between States and Nationals of Other States (ICSID), (1965).

${ }^{11}$ Yackee (2009) at 1554; Guzman, Elkins \& Simmons (2006); Nash (1993) a4 433.

${ }^{12}$ Franck (2005) at 1522-1523; Carlos (2004) at 304-305.
} 
judicial recourse against an offending host state has historically been dependent on their home governments willingness to plead on their behalf, through a diplomatic channel. Consequently private investment disputes were turned into political issues. ${ }^{13}$ With almost every modern BIT now providing for a dispute settlement mechanism through the ICSID $^{14}$, consenting to the treaties is tantamount to developing countries undermining the independence, sovereignty and control that they have historically fought so hard to protect.

It is clear that the political independence of developing countries even in the third millennium has not translated into economic independence. Studies on the effects of BITs on developing countries have been conflicting. While some have concluded that the treaties in fact have positive effects on FDI inflows ${ }^{15}$, others have indicated that the effect is little, negligent or insignificant. ${ }^{16}$ Whichever way we look at the situation, the one thing that has become obvious is the fact that the inflow of FDI into developing countries is conditioned on the latter sacrificing their sovereignty for credibility. ${ }^{17}$ Thanks to their stringent provisions, BITs tend to function as facilitators par excellence in stabilising this unusual relationship. They are for lack of a better expression, instruments of Economic Hegemony.

\section{Examining Typical BITs Clauses}

The mad rush of BITs by the third world is revealing of how far these countries have deviated from their past, transcending from their suspicions of the FDI regime to enthusiastically embracing investment liberalization. Such a liberal thinking has facilitated "the adoption of similar investment protection provisions and international law formulas, which stipulate the extent and type of compensation in the event of expropriation." 18

Despite the uniformity of the clauses, they exhibit such a high level of ambiguity as to fail to mean one and the same thing. Consequently, in order to grasp what National Treatment, Most Favoured Nation, Fair and Equitable Treatment and Dispute Settlement clauses really stand for, it would be imperative to separate their literal meaning from their practical intent. For instance, literally, national treatment implies that foreign investors may not be treated any worse than national investors in the same line of business. Both case law and academic scholarships have however suggested that in actual sense, the foreign investors are expected to be treated better (and often are) than the national investors. ${ }^{19}$

\footnotetext{
${ }^{13}$ Goodman (2007) at 455, 457. (Explaining how investors previously had little ability to country court access. Their ability depended on their home governments).

${ }^{14}$ Convention on the Settlement of Investment Disputes between States and Nationals of Other States (ICSID), (1965), 575 United Nation Treaty Series (U.N.T.S) 159, 4 Int'l Legal Materials 524 (1965).

${ }^{15}$ Neumayer \& Spess (2005) at 1571-3; Salacuse \& Sullivan (2005) at 67-71.

${ }^{16}$ Tobin \& Rose-Ackerman (2005).

${ }^{17}$ See generally Guzman (1998).

${ }^{18}$ See Chalamish (2009) at 324.

${ }^{19}$ See Neumayer \& Spess (2005) at 1570. See also Marvin Roy Feldman Karpa v. United Mexican States, ICSID Case No. ARB(AF)/99/1, (16 December 2002).
} 
Although dubbed as "common goals" of the signatories, BITs provisions in real sense are far from being neutral. Most of the provisions are aligned with investors' interests and pay little regard to the sovereignty of the host nation. ${ }^{20}$ Consequently, the foreign investors end up enjoying not only higher security but better treatment than the domestic investors. ${ }^{21}$ Developing countries generally sign the treaties from a vulnerable angle, with very limited, if any negotiating power. ${ }^{22}$ With neighbours and fellow developing countries all competing for the same FDI for economic growth, the extent to which host states are sacrificing their sovereignty for credibility is enormous. ${ }^{23}$ Consequently, virtually any public policy regulation by the host state can potentially be challenged whenever foreign investors construe it to affect them. ${ }^{24}$ Given the ambiguity of BITs clauses, there is a high tendency that host states might become susceptible to several arbitration proceedings to which they have not necessarily agreed. ${ }^{25}$ It follows that the undefined aspects of BITs clauses are just as relevant as their stated function.

\section{Fair and Equitable Treatment Provision}

To many, the tendency would be to qualify the defunct 1948 Havana charter for an International Trade Organization (ITO) as long dead and buried. Such an assertion could be valid from a purely restrictive point of view. If we however take a holistic approach, it would be observed that even though the body of the obsolete treaty has truly been buried, its soul was never. In fact, the ghost of one of its remnant clauses: "Just and Equitable Treatment" has very much been alive, and even evolve to become a central part of international investment protection. Under the ITO, the concept was used as a tool for the promotion of bilateral or multilateral agreements on measures designed to assure Just and Equitable Treatment for the enterprise, skills, capital, arts and technology brought from one member country to another. ${ }^{26}$ Despite the collapse of the ITO negotiations, the clause has been subsequently revived and reshaped through various legal instruments. ${ }^{27}$ It has been invoked at virtually every multilateral negotiation on

\footnotetext{
${ }^{20}$ See Vandevelde (1998) at 514.

${ }^{21}$ See Neumayer \& Spess, (2005) at 1570.

${ }^{22}$ See Chung (2007).

${ }^{23}$ See generally, Guzman (1998).

${ }^{24}$ See Neumayer \& Spess (2005) at 1571.

${ }^{25}$ See Chalamish (2009) at 333.

${ }^{26}$ See Article II (2), 1948 Havana Charter for an International Trade Organization.

${ }^{27}$ Despite some variations in form and content, the clause has been adopted by various international instruments, most notably: the 1948 ninth International Conference of American States, Bogota (Article 22), the US treaties on FNCs, the 1959 Draft Convention on Investments Abroad, the 1967 OECD Draft Convention on the Protection of Foreign Property (Article 1 (a)), and the North Atlantic Free Trade Agreement (NAFTA, Article 1105). Like the ITO, most of these instruments have flopped as well. Article 11 (2)(i) of the ITO stipulated that the Organisation would assure "Just and Equitable Treatment for the Enterprise, skills, Capital, Arts and Technology brought from one member country to another." The draft OECD Convention on the Protection of Foreign Property, 1967, in its Article 1(a) titled "Treatment of Foreign Property", provided that "Each party shall at all times ensure Fair and Equitable
} 
investment. It is however in modern BITs that the concept has surged in popularity, under a new nomenclature: "Fair and Equitable Treatment" (FET). Host states are required to provide Fair and Equitable Treatment to the investments and investors of the other treaty party. ${ }^{28}$

Despite the "beguiling simplicity" 29 of the phrase and its widespread usage, what constitutes "Fair" and "Equitable" treatment remains vague and elusive, thus providing space for a host of different interpretations. It is often stated together with other standards. However, unlike those other standards which are relative in character (National Treatment and Most Favoured Nation clauses), Fair and Equitable Treatment is an absolute, non-contingent standard, implying that its exact meaning can only be determined by reference to the specific circumstances of application. ${ }^{30}$ It is at the centre of virtually every BIT arbitration. Infect, a recent UNCTAD study reveals that FET remains the most relied upon and successful basis for a treaty claim. All 13 investment decisions that were rendered in 2008 on their merits for example had a claim based on FET that was addressed by the tribunal. $^{31}$ The vagueness and expansiveness of the concept has led tribunals, government officials and scholarly commentators to arrive at conflicting conclusions regarding the interpretation of its normative content. What does Fair and Equitable Treatment as a legal concept require of host states when engaging with foreign Investors? ${ }^{32}$ Is the standard measured against Customary International Law Minimum Standard, a more expansive international law standard or is it a self contained independent principle that is additional to general international law?

Meanwhile most of the debate has oscillated between FET as synonymous to the minimum standard of protection required by international law and the concept as an autonomous self-contained principle, yet another school of thought has opined that the FET is a deliberate delegation of authority to investment tribunals to autonomously and actively develop standards of fairness and equitableness for international investment relations. ${ }^{33}$ It is assumed that this flexibility and vagueness is essential in order to give arbitrators the possibility to articulate a range of principles necessary to achieve the treaty's purpose in a given case. ${ }^{34}$ Given the growing number of BITs arbitral awards examining claims of host states' denial of FET, the implication of each of these discussions could be very broad.

The minimum standard of protection has been the object of tensions between the developed and developing countries. The standard is to the effect that foreign

\footnotetext{
Treatment to the property of the nationals of the other parties. It shall accord within its territory the most constant protection and security to such property and shall not in any way impair the management, maintenance, use, enjoyment or disposal thereof by unreasonable or discriminatory measures.

${ }^{28}$ See Kill (2007) at 834.

${ }^{29}$ See McLachlan, Shore \& Weiniger (2007); cf. Malnik (2009). "Fairness" and "Equity" and fundamental principles recognized by virtually every legal system.

${ }^{30}$ See Yannaca-Small (2004) at 2.

${ }^{31}$ UNCTAD 2009 a 8.

${ }^{32}$ See Tudor (2009) at 236. See also Schreuer (2005).

${ }^{33}$ Brower (2003).

${ }^{34}$ See Yannaca-Small (2004) at 2.
} 
investors are entitled to a minimum level of treatment, and any treatment which falls short of this standard would give rise to international responsibility on the part of the violating state. ${ }^{35}$ The classic application of the concept has been traced to the $20^{\text {th }}$ century case of Neer V. Mexico $(1926)^{36}$, which posited that the treatment of an alien, in order to constitute an international delinquency, "should amount to an outrage, to bad faith, to wilful neglect of duty, or to an insufficiency of governmental action so far short of international standards that every reasonable and impartial man would readily recognize its insufficiency."37 Although this paradigm has long stood out as an articulation of customary international law, some tribunals have recently observed that the standard has since evolved. ${ }^{38}$ It has been shaped by the conclusion of FCNs and BITs, all of which largely and concordantly "provide for Fair and Equitable Treatment and for full protection and security for the foreign investor and his investment." 39 Even if there was once a cloud of doubt over the minimum standard of treatment as a norm of customarily international law, this is no longer the case, given the global proliferation of BITs. Considering that the minimum standard of protection is now an acceptable international legal standard, it can be deduced that if it is synonymous to FET as suggested by some scholars ${ }^{40}$, then it goes without saying that the parties actually intended to impose a stricter standard than that reflected in customary law.

I find the above thesis tying FET to the minimum standard to be unconvincing and the suggestion that FET is an autonomous concept and a deliberate delegation of authority to investment tribunals to actively develop standards of fairness and equitableness for international investment relations to be persuasive. A closer observation of BITs illustrate that in the absence of a clear indication to the contrary, FET is intended to stand as an independent concept. If parties to a BIT intended an observance of minimum standard of protection, they would have referred to it as such, instead of using a different expression. ${ }^{41}$ According to F.A. Mann, who clearly supported FET as an independent concept:

\footnotetext{
${ }^{35}$ See Yannaca-Small (2004) at 8.

${ }^{36}$ See LFH Neer \& Pauline Neer (USA) v. United Mexican States (1926) IV RIAA 60. The facts of this case are that Paul Neer, a US citizen was murdered in Mexico. The US government accused its Mexican counterpart of showing a total lack of diligence to investigate and prosecute the crime. A joint US-Mexico General Claims Commission was charged with laying down a uniform standard of protection.

${ }^{37}$ Ibid

${ }^{38}$ See for example, Mondev International Ltd $v$. United States, Award, ICSID Case No $A R B(A F) / 99 / 2$; IIC 173, (2002) (hereinafter Mondev case). Also, in the Pope \& Talbot case ( Pope \& Talbot V. Canada, Award, April 10th 2001, 7 ICSID Reports, 102), the tribunal observed that the ICJ in the ELSI case had since moved away from the Neer formulation by replacing the requirement of "every reasonable and impartial person" with a higher threshold of investor protection against the state conduct.

${ }^{39}$ See Mondev case, para 125.

${ }^{40}$ See for instance Gann (1985); Paterson (1991).

${ }^{41}$ See Schreuer (2005) at 360. Schreuer posits that it would be unlikely for a BIT to use FET to denote a well-known concept such as the minimum standard of treatment in customary international law. See also UNCTAD 1999, at 3-28.
} 
The terms 'Fair and Equitable treatment' envisage conduct which goes far beyond the minimum standard and afford protection to a greater extent and according to a much more objective standard than any previously form of words. A tribunal would not be concerned with a minimum or maximum or average standard. It would have to decide whether in all circumstances the conduct in issue is fair and equitable or unfair and inequitable. No standard defined by other words is likely to be material. The terms are to be understood and applied independently and autonomously. ${ }^{42}$

Being an autonomous independent concept, FET can as the case may be, normally complement, incorporate or overlap with the minimum standard of treatment. The relationship between FET and the minimum standard of protection is succinctly illustrated in Article 1105(1) of the North American Free Trade Agreement (NAFTA).The section reads thus:

\section{"Article 1105: Minimum Standard of Treatment}

1. Each party shall accord to investments of investors of another party treatment in accordance with international law, including Fair and Equitable Treatment and full protection and security. ${ }^{, 43}$

At least two features stand out from this provision. Although it is captioned as "Minimum standard of treatment", it mentions FET as an additional standard ("including Fair and Equitable Treatment"), and not as a synonym to the Minimum Standard of Treatment. The caption "Minimum standard of treatment" is also suggestive of a direct reference to international law, implying that FET is an additional requirement to the general standard required by customary international law. It's mentioning under the "Minimum standard of treatment" without further explanation however seems to be a deliberate delegation of authority to investment tribunals to actively develop standards of fairness and equitableness for international investment relations on a case-by-case basis.

The main characteristics of FET is thus its flexibility in allowing the tribunal to "evaluate and balance the circumstances of the case in front of him before applying the standard and its sanction [...] using intuition and expertise"44 Tudor observes that FET actually has no standard or fixed content. ${ }^{45}$ How can a standard with no standard and without a fixed content, one wonders, become a norm of customary international law? I consider Tudor's assertion to be an overstatement of the ambiguity contiguous to FET. Although FET does not come across as a traditional "rule" of international law, it nonetheless stands out as a veritable "standard". It is articulated in such a way that arbitrators can always exploit its flexibility in every given case to give it meaning. The tribunal in the Mondev case explicitly stated that a judgment of what is fair and equitable "cannot be reached in the abstract: it must depend on the facts of the particular case." 46

\footnotetext{
${ }^{42}$ Mann (1981) at 244. Cf. Schreuer (2005) at 360.

${ }^{43}$ Article 1105 (1) of NAFTA, 33 I.L.M (1993), p. 639.

${ }^{44}$ See Tudor (2009) at 120.

${ }^{45}$ See Tudor (2009) at 133.

${ }^{46}$ See Mondev International Ltd v. United States, Award, ICSID Case No ARB(AF)/99/2; IIC 173, (2002), para 118.
} 
In Pope \& Talbot v. Canada $(2001)^{47}$, the tribunal found that the requirement of "Fair and Equitable Treatment" in Article 1105 of the North American Free Trade Agreement (NAFTA) was not limited to customary international law (minimum standard of treatment), but rather additional to the requirements of international law. ${ }^{48}$ Given its broad nature, the mere fact that a host state has breached a rule of international law would weigh heavily in finding a breach of FET. $^{49}$

\section{National Treatment Clause}

Modern BITs typically recognise the ability of a host state to restrict the access of foreign investors only within the contours of domestic regulatory framework. ${ }^{50}$ A National Treatment clause thus requires host states to accord to foreign investors the same treatment that it accords its nationals in similar circumstances. ${ }^{51}$ Accordingly, the host state cannot discriminate amongst investors based on nationality. The clause is the first of the two pillars on non-discrimination (the other being Most-Favoured Nation Clause). ${ }^{52}$ In principle the aim of the provision is to promote investment neutrality through the provision of a level playing field for foreign investors in the post-establishment phase. In practice however, it is just another loaded concept shrouded in ambiguity. At least one tribunal has ruled that a discriminatory measure is one that fails to provide for national treatment. ${ }^{53}$ The ruling has however failed to indicate whether the two standards are identical. There is no obligation under Customary International Law requiring host states to treat foreign investors in the same way as they treat nationals. ${ }^{54}$

Technically-speaking, National Treatment is supposed to have a very narrow application, since it is generally required only where the foreign investor and the domestic investor find themselves in identical or similar circumstances/ situations. ${ }^{55}$ However, despite its prevalence in BITs, the phrase "similar

\footnotetext{
${ }^{47}$ Pope \& Talbot V. Canada, Award, April 10th 2001, 7 ICSID Reports, 102, paras 105-118

${ }^{48}$ Chapter XI of the agreement regulates the operation of BITs in the region.

${ }^{49}$ See Schreuer (2005) at 364

${ }^{50}$ See Adlung \& Molinuevo (2008) at 379

${ }^{51}$ See Dolzer \& Stevens (1995) at 63. See also UNCTAD 2005 at. 32. See also Article 1102 (2) of NAFTA, which provides thus:

"Each Party shall accord to investments of investors of another Party treatment no less favorable than it accords, in like circumstances, to investments of its own investors with respect to the establishment, acquisition, expansion, management, conduct, operation, and sale or other disposition of investments."

${ }^{52}$ See Trebilcock \& Giri (2004)

${ }^{53}$ See Ronald S. Lauder v. The Czech Republic, Final Award, $3^{\text {rd }}$ Sep. 2001, 9 ICSID Reports, para. 220.

${ }^{54}$ See Brownlie (2008) at 524-528. Cf. Brown (2009) at 64.

${ }^{55}$ Examples of the stipulation abound. Article 2 of the Turkey-Nigeria BIT reads thus:

"Each party shall accord to these investments, once established, treatment no less favourable than that accorded in similar situation to investments of its investors or to investments of investors of any third country, whichever is the most favourable". Article 3 (1) of the UK-Belize BIT (1982) provides that: "Neither contracting party shall in its
} 
circumstances" or "similar situations" or "like circumstances" remains unclear and is still open to a wide variety of interpretations in the abstract and in the context of a particular dispute. Does it imply that the domestic investor must be doing exactly the same business as the foreign investor, or similar activity, or is it dependent on the country's investment code? What differential treatment would amount to a violation of National Treatment? Must it be a difference in law (de jure) or simply a difference in effect (de facto) $?^{56}$ Which policies of the host state may justify a differential treatment between the foreign investor and the domestic investor? ${ }^{57}$

Existing case law has neither been consistent on the issue nor has it answered all the above questions. Tribunals have generally applied the standard differently, depending on whether they have understood "like circumstances" to be restrictive or elastic in nature. Where a restrictive view has been taken, the tribunal has asserted that "in like circumstances" refers to the same line of business. ${ }^{58}$ In other situations, an elastic interpretation has been advanced, for instance, that considering the natural wide connotation attributed to "like circumstances" it goes without saying that the concept extends to commercially competitive economic and business sectors. ${ }^{59}$ One major difference between the cases is that while the Marvin Roy Feldman tribunal requires a mere evidence of discrimination to proof nationality-based discrimination, a much higher standard is expected under the S.D. Myers ruling. ${ }^{60}$

territory subject investments or returns of nationals or companies of the other contracting party to treatment less favourable than that which it accords in the same circumstances to investments or returns of its own nationals."

Article 2(2) of the US-Senegal BIT (1983) talks of "treatment not less favourable than that which it accords in like situations to investments and associated activities of its own nationals or companies". See also Article 1102 (2) of NAFTA.

${ }^{56}$ See Mann \& von Moltke (2004).

${ }^{57}$ See Dolzer (2005).

${ }^{58}$ See for example, Marvin Roy Feldman Karpa v. United Mexican States, ICSID Case No. $A R B(A F) / 99 / 1$, (16 December 2002), para. 171. (Consequently, the tribunal suggested that violation could be applicable if the investment involved the same business, that is, the export of cirgarettes).

${ }^{59}$ See for instance: S.D. Myers Inc. v. Canada, First Partial Award of November 13, 2000 (Hunter, Chiasson, Schwartz), 40 ILM 1408 (2001), para. 250. The tribunal stated thus:

"The Tribunal considers that the interpretation of the phrase "like circumstances" in Article 1102 must take into account the general principles that emerge from the legal context of the NAFTA, including both its concern with the environment and the need to avoid trade distortions that are not justified by environmental concerns. The assessment of "like circumstances" must also take into account circumstances that would justify governmental regulations that treat them differently in order to protect the public interest. The concept of "like circumstances" invites an examination of whether a non-national investor complaining of less favourable treatment is in the same "sector" as the national investor. The Tribunal takes the view that the word "sector" has a wide connotation that includes the concepts of "economic sector" and "business sector". (Para 250).

${ }^{60}$ The Marvin Roy Feldman in para. 181 took the following position:

"it is not self-evident, as the Respondent argues, that any departure from national treatment must be explicitly shown to be a result of the investor's nationality. There is no such language in Article 1102. Rather, Article 1102 by its terms suggests that it is sufficient to show less favourable treatment for the foreign investor than for domestic investors in like circumstances[...]For practical as well as legal reasons, the Tribunal is prepared to assume 
Since the situations of the foreign investor and the domestic investor are rarely identical, it has been observed that the application of the National Treatment provision may well be a difficult task. ${ }^{61}$ It still leaves a few unanswered questions. For example, how would the concept apply where both the domestic and the foreign investors are both subject to unfair treatment from the host state? Does the concept come on the defence of both investors or does it apply selectively for the benefit of the foreign investor? Does the clause involve a comparison with the average national or a wealthy national? Although there are no clear-cut answers to these questions, it can nonetheless be implied from the general reading of the provision that in any event, the real interpretation of national treatment means that the foreign investor has to be treated better than the domestic investor, whenever they find themselves in similar situations. This is because he is naturally entitled to all the benefits enjoyed by domestic investor as well as any other rights that the host state may have contracted with investors of third countries. ${ }^{62}$

\section{Most Favoured Nation (MFN) Clause}

Modern BITs generally contain some form of Most Favoured Nation (MFN) provision. The clause typically seeks to extend to foreign investors of one contracting state treatment which is not less favourable than that which the host state accords to nationals of any other third country. ${ }^{63}$ Soon after the Second World War, there were some calls for a clarification of the scope of MFN clauses in International treaties. ${ }^{64}$ The International Law Commission (ILC) responded by

that the differential treatment is a result of the Claimant's nationality, at least in the absence of any evidence to the contrary."

On the Contrary, the S.D. Myers tribunal ruled that "Intent is important, but protectionist intent is not necessarily decisive on its own. The existence of an intent to favour nationals over nonnationals would not give rise to a breach of Chapter 1102 of the NAFTA if the measure in question were to produce no adverse effect on the non-national complainant. The word "treatment" suggests that practical impact is required to produce a breach of Article 1102, not merely a motive or intent that is in violation of Chapter 11". (para. 254).

${ }^{61}$ See Dolzer \& Stevens (1995) at 63

${ }^{62}$ See MFN Clause below. Article 3 (1) of the UK-Belize BIT (1982) for instance provides that: "Neither contracting party shall in its territory subject investments or returns of nationals or companies of the other contracting party to treatment less favourable than that which it accords in the same circumstances to investments or returns of its own nationals."

${ }^{63}$ See Dolzer \& Stevens (1995) at 65. See also Schill (2009) at 502, and see also Trebilcock \& Howse, (2005) at 49. As a sine qua non, more favourable treatment must be accorded to a third state for the MFN provision to be invoked, since the rights of the beneficiary state are derived from the treaty between the granting state with a third state. The clause has been used since the $12^{\text {th }} \mathrm{C}$. Its genesis is traced to a 1226 treaty in which King Frederick II conceded the privileges previously afforded to Pisa and Genoa to the city of Marseilles. It was subsequently used to prevent discrimination in International Trade. (See Radi, 'The application of the most favoured nation clause to the dispute settlement provisions of bilateral investment treaties: Domesticating the Trojan Horse' 18 EJIL, (2007), pp. 757, 759, See also Freyer \& Herlihy (2005),

${ }^{64}$ See Ziegler (2008), 'Most-Favoured Nation (MFN) Treatment', in: Reinisch (ed.), Standards of Investment Protection, (2008), pp. 29-86. Cf. Ziegler (2010) at 77. 
adopting the so-called Draft Articles on the Most Favoured Nation Clause (ILC Draft Articles) during its $30^{\text {th }}$ session in 1978. According to Article 4, "[A] Most Favoured Nation clause is a treaty provision whereby a state undertakes an obligation towards another state to accord most favoured nation treatment in an agreed sphere of relations." ${ }^{65}$ Article 5 is more explicit. It defines the provision as "treatment accorded by the granting state to the beneficiary state, or to persons or things in a determined relationship with that state, not less favourable than treatment extended by the granting state to a third state or to persons or things in the same relationship with that third state." ${ }^{, 66}$ If for instance, Finland and Cameroon sign a BIT with an MFN clause, France which although not a contracting party to this BIT but having signed a similar treaty with Cameroon can rely on one of Finland-Cameroon BIT clauses which accords extra protection to Finnish investors. Similarly, Finnish investors can depend on the extra protections in the France-Cameroon BIT. In this case, each of the treaties establishes the judicial link between the beneficiary state and the third state. ${ }^{67}$

As in the case of National Treatment, the MFN provision is significant because it out rightly prohibits discrimination on the basis of nationality or source of origin of the investment, thus purportedly allowing investors to claim ensuring an efficient allocation of resources. ${ }^{68}$ It has however been observed that the clause is a break from general international law and its bilateralist rationale because in principle, it "permits States to accord differential treatment to different States and their nationals and instead ensure equal treatment between the State benefiting from MFN treatment and any third State." 69

Although the standard is credited for creating "an equality of competitive opportunities" between the different foreign investors, it has also been observed that it also "limits the host countries' room for manoeuvre with respect to future investment agreements, as it obliges the host country to unilaterally extend to investors from treaty partners any additional rights that it grants to third countries in future agreements". ${ }^{70}$ Theoretically, BITs are treaties involving just two countries, thus citerus paribus (everything being equal) should exhibit a bilateral character. But as has been noted before, the treaties are unique in that their provisions necessarily lead to international ramifications. As a result, a MFN provision is also a source of international obligation other than those included in the basic treaty. ${ }^{71}$

\footnotetext{
${ }^{65}$ See Article 4, ILC Draft Articles on Most Favoured Nation Clause, $30^{\text {th }}$ Session, $8^{\text {th }}$ May-28 $8^{\text {th }}$ July 1978, Supplement No. 10, Doc A/33/10, 2 Y.B of I.L.C. (1978), 8. It is worth noting that the ILC suspended its work on the issue after this adoption.

${ }^{66}$ Ibid

The US Model BIT in the relevant section provides that "Each party shall accord to investors of the other party treatment no less favourable than that it accords, in like circumstances, to investors of any non-party with respect to the establishment, acquisition, expansion, management, conduct, operation, and sale or other disposition of investments in its territory..." (See Article 4, U.S. Model Bilateral Investment Treaty, (2004)).

${ }^{67}$ See Houde, (2004) at 9.

${ }^{68}$ Ranjan (2007) at 67. See also Vesel (2007) at 141.

${ }^{69}$ See Schill (2009) at 502.

${ }^{70}$ See UNCTAD 1999.

${ }^{71}$ See Ziegler (2010) at 79
} 
Since the MFN provision naturally necessitates two separate BITs, it is always imperative for tribunals to first of all determine the basic treaty that contains the MFN from the third party treaty. In the Anglo- Iranian Oil Company $\operatorname{case}^{72}$, the International Court of Justice (ICJ) determined that the basic treaty is that containing the Most-Favoured Nation Provision. In the words of the Court, the treaty containing the Most Favoured Nation clause is

"[...] the treaty which establishes the juridical link between the United Kingdom (the beneficiary state) and the third party treaty and confers upon that state the rights enjoyed by the third party. A third party treaty, independent of and isolated from the basic treaty, cannot produce any legal effect as between the United Kingdom (the beneficiary state) and Iran (the granting state): It is res inter alios acta" ${ }^{\text {,73. }}$.

In other words, the MFN clause is contained in the basic treaty, meanwhile the more favourable treatment is found in the third party treaty. ${ }^{74}$

For the MFN provision to be applied, the object of the basic treaty and the third party treaty must not be different in nature.

It is worth noting that it is entirely permissible under customary international law for states to freely enter into bilateral quid pro quo bargains that extend preferential treatment to the other contracting party. ${ }^{75}$ The MFN provision seemingly stands out to prohibit this practice. Is this a constructive or regrettable shift? Is the MFN clause therefore an absolute provision? Is the clause limited to substantive treatment or extends to dispute settlement as well? That is, can foreign investors invoke the MFN clause to establish jurisdiction over investment disputes with host states? ${ }^{76}$

The scope of the MFN provision with respect to dispute settlements under BITs has in recent years become a point of interest for both arbitrators and legal scholars, whose divergence in opinion have raised rather more questions than answers about the correct interpretation of the standard. ICSID tribunals have in particular taken conflicting positions on whether investors can rely on the MFN provision to invoke the dispute resolution provisions of a third party BIT that are comparatively more favourable to the investor. ${ }^{77}$ The problem has been addressed in Maffezini, Salini, Siemens and Plama cases (amongst other cases) with seemingly divergent decisions. ${ }^{78}$ Despite the divergences, the cases nonetheless highlight an attempt to harmonize investors' rights as well as a

\footnotetext{
${ }^{72}$ Anglo-Iranian oil Co. (U.K. v. Iran), July 22 1952, I.C.J, p. 93.

${ }^{73}$ See para. 109.

${ }^{74}$ See generally Gaillard (2005).

${ }^{75}$ See Ziegler (2010) at 79.

${ }^{76}$ See Fietta (2005).

${ }^{77}$ See Wong (2008) at 173.

${ }^{78}$ Emilio Agustion Maffezini V. Kingdom of Spain, ICSID Case No. ARB/97/7, Decision of January 25, 2000;

Salini Construttori S.p.A and Italstrade S.p.A V. The Hashemite Kingdom of Jordan, ICSID Case No. ARB/02/13, Decision of November 15, 2004; Siemens A.G. V. The Argentina Republic, ICSID Case No. ARB/O2/8, Decision of August 3, 2004; Plama Consortium Limited V. Republic of Bulgaria, ICSID Case No. ARB/03/24, Decision of February 8, 2005.
} 
reaffirmation of the quasi-multilateral aspect of BITs. ${ }^{79}$ While Maffezini and Siemens tribunals determined that MFN clauses apply to dispute settlement provisions, the tribunals in Salini and Plama on the other hand ruled that MFN clauses in BITs were not intended to extend to dispute settlement provisions.

\section{Maffezini v. Kingdom of Spain $^{80}$}

The Maffezini case concerned a dispute between the State of Spain and an Argentine investor, Mr. Emilio Agustin Maffezini, regarding the latter's investment in an enterprise called EAMSA (specialised in the production and distribution of chemical products in the Spanish region of Galicia). Having set up his business under the Spain-Argentina BIT, he later sought the application of the MFN clause contained in Article IV (2) ${ }^{81}$ of the said treaty, so that he could benefit from the more favourable provision in the 1991 Spain-Chile BIT. Unlike the Spain-Argentina BIT that required a preliminary waiting period of eighteen (18) months for the exhaustion of local remedies before any referral to an ICSID tribunal in case of disputes, a corresponding Spain-Chile BIT allowed investors to opt for international arbitration after a six months negotiation period. ${ }^{82}$ The contention of Maffezini was that since Spain accorded Chilean investors more favourable treatment than Argentine investors, in the absence of any exceptions, it can be deduced from the Spain-Argentina BIT that the MFN clause was intended to give Argentine investors the option to benefit from the more favourable treatment enjoyed by other foreign investors (Chilean investors) in this case). ${ }^{83}$ Upon determining that the claimant had satisfied the ejusdem generis standard, ${ }^{84}$ the tribunal sustained most of Maffezini's claims while at the same time rejecting Spain's argument that the application of the MFN clause was limited to substantive matters of treatment to investors and did not cover procedural or jurisdictional questions. ${ }^{85}$ In the opinion of the tribunal,

Notwithstanding the fact that the basic treaty [...] does not refer expressly to dispute settlement as covered by the Most Favoured Nation clause, the Tribunal considers that there are good reasons to conclude that today dispute settlement arrangements are inextricably related to the protection of foreign investors. ${ }^{86}$

As a result, it reached the conclusion that:

\footnotetext{
${ }^{79}$ See Chalamish (2009) at 324.

${ }^{80}$ See Emilio Agustion Maffezini V. Kingdom of Spain, ICSID Case No. ARB/97/7, Decision of January 25, 2000.

${ }^{81}$ Article IV is to the effect that "In all matters subject to this agreement, this treatment shall not be less favourable than that extended by each Party to the investments made in its territory by investors of a third country".

${ }^{82}$ See Article 10 (2) of the Spain-Chile BIT.

${ }^{83}$ Maffezini Para. 40

${ }^{84}$ This principle requires that the MFN attracts only matters belonging to the same subject matter as that to which the clause itself relates. (See Commission of Arbitration in the Ambatielos case, U.N. Reports of Int'l Arbitral Awards, 1963, 107).

${ }^{85}$ Maffezini, Paras 53, 64.

${ }^{86}$ Ibid, Para 54.
} 
If a third party treaty contains provisions for the settlement of disputes that are more favourable to the protection of the investors' rights and interests than those of those in the basic treaty, such provisions may be extended to the beneficiary of the Most Favoured Nation clause, as they are fully compatible with the ejusdem generis principle. ${ }^{87}$

In rendering the decision, the tribunal mostly based its verdict on the language of the BIT, such as possible intent of the parties, the policies and economic considerations that shaped the parties negotiations, as well as the practice of the Spanish government in concluding its BITs. ${ }^{88}$ Meanwhile the MFN clauses explicitly provide for the provisions on dispute settlement in some BITs, in many others, it merely outline various rights contained in the agreement without actually making any mention of dispute settlement. ${ }^{89}$ Even in the latter cases, silence would not necessarily imply non-existence. In fact, the Maffezini tribunal drew a clear distinction between the "legitimate extension of rights and benefits by means of the operation of the [MFN] clause, on the one hand, and disruptive treaty-shopping that would play havoc with the policy objectives of underlying specific treaty provisions, on the other hand". ${ }^{90}$ Despite its ruling in favour of Maffezini, it nonetheless warned that investors must not be allowed to override public policy considerations that the "contracting parties might have envisaged as fundamental conditions for their acceptance of the agreement in question." 11

\section{Siemens A.G. V. The Argentina Republic ${ }^{92}$}

The situation and the ruling in Siemens are both similar to that in the Maffezini case. The tribunal was faced with the question whether foreign investors could initiate arbitration after a six months negotiation period as stipulated in the Chile-Argentina BIT or do that only after the exhaustion of local remedies during an 18 months period as required in the German-Argentina BIT. The tribunal found in favour of a claimant who relying on the Maffezini case sought to avoid the application of the 18 months waiting period by invoking the third party treaty with Chile. Unlike the Maffezini case, the wording of the MFN clause did not allow for more favourable treatment as regards all matters related to the basic treaty. ${ }^{93}$ Despite the narrowness in formulation, the tribunal

\footnotetext{
${ }^{87}$ Ibid, Para 56.

The tribunal determined that the total amount of compensation and interests that Spain must pay Maffezini sums up to 58 million Spanish Pesetas. (See Paras 33, 97).

${ }^{88}$ Maffezini Para. 42. See also Chalamish (2009), at 327.

${ }^{89}$ See Houde (2004) at 13.

${ }^{90}$ Maffezini, Para 63.

${ }^{91}$ Ibid Para. 62.

${ }^{92}$ See Siemens A.G. V. The Argentina Republic, ICSID Case No. ARB/O2/8, Decision of August 3, 2004.

${ }^{93}$ Siemens Para. 31.

Article 3 of the Germany-Argentina BIT read thus: “(1) Neither Contracting Party shall subject investments in its territory by or with the participation of nationals or companies of the other Contracting Party to treatment less favourable than it accords to investments of its own nationals or companies or to investments of nationals or companies of any third State. (2)
} 
took an understanding that this was a mere distinction without a difference, hence determining that the dispute settlement provisions were well within the scope of the MFN provision. ${ }^{94}$ As it noted, the basic treaty contained

"[...] as a distinctive feature, special dispute settlement mechanisms not normally open to investors. Access to these mechanisms is part of the protection offered under the treaty. It is part of the treatment of foreign investors and investments and of the advantages accessible through an MFN clause [...]. The term 'treatment' and the phrase 'activities related to the investments' are sufficiently wide to include settlement of disputes." 95

Salini Construttori S.p.A and Italstrade S.p.A v. The Hashemite Kingdom of Jordan ${ }^{96}$

Adopting a rather different approach from the Maffezini and Siemens jurisprudence, the tribunal in Salini V. Jordan found that MFN clauses of the applicable BIT were not intended to extend to the dispute settlement provisions, on the basis of the specific language of that clause. The case involved a dispute arising out of the construction of the Karameh dam in Jordan by two Italian companies. The Italian claimants sought to bring contractual claims against Jordan before the ICSID tribunal, despite their prior agreement to first exhaust local remedies, on the ground that Jordan's BITs with the USA and UK allowed American and British investors to invoke arbitration, and by the same token, the MFN clause in the Italy-Jordan BIT "naturally" entitled Italian investors to enjoy the same procedural treatment. ${ }^{97}$

Article 9 (2) provided that

"In case the investor and an entity of the Contracting Parties have stipulated an investment Agreement, the procedure foreseen in such investment agreement shall apply." 98 The MFN clause in the Italy-Jordan BIT provided that "both Contracting Parties, within the bounds of their own territory, shall grant investments effected by, and the income accruing to, investors of the Contracting Party no less favourable treatment than that accorded to investments effected by, and income accruing to, its own nationals or investors of Third States."

\footnotetext{
Neither Contracting Party shall subject nationals or companies of the other Contracting Party, as regards their activity in connection with investments in its territory, to treatment less favourable than it accords to its own nationals or companies or to nationals or companies of any third State."

${ }^{94}$ Siemens para. 184.

${ }^{95}$ Ibid Paras 102, 103.

${ }^{96}$ See Salini Construttori S.p.A and Italstrade S.p.A V. The Hashemite Kingdom of Jordan, ICSID Case No. ARB/02/13, Decision of November 15, 2004.

${ }^{97}$ Article IX of the Italy-Jordan BIT (Agreement on the Promotion and Protection of Investments, Italy-Jordan, July 21, 1999) specifically referred contractual disputes to Jordanian domestic courts. See also Salini, Para. 36.

${ }^{98}$ See Article 9 (2) of the Italy-Jordan BIT.

${ }^{99}$ See Article 3 of the Italy-Jordan BIT.
} 
The tribunal observed that Article 3 of the Italy-Jordan BIT was silent on the application of the MFN clause to the dispute settlement mechanism. ${ }^{100} \mathrm{It}$ then made an important distinction between MFN provisions that expressly provide for dispute settlement from those that do not. ${ }^{101}$ Unlike the situations in Maffezini and Siemens, the Italy-Jordan BIT did not contain a provision envisaging "all rights" or "all matters" covered by the agreement.

The jurisprudence laid down in Maffezini and Siemens is to the effect that the intent of the parties is absolute; therefore, the interpretation of the MFN clause should not defeat public policy concerns. As far back as the Ambatielos case (1956), the ICJ observed that "the question is whether the consent given by the parties...to arbitrate a certain category of disputes [ ] does or does not extend to the [claimant's] claim."102

Based on this caveat, the Salini tribunal determined that the common intention of the parties was clearly not to have the MFN provision apply to dispute settlement mechanism. ${ }^{103}$ In the words of the tribunal:

Quite on the contrary, the intention as expressed in Article 9(2) of the BIT was to exclude from ICSID jurisdiction contractual disputes between an investor and an entity of a State Party such that such disputes might be settled in accordance with the procedures set forth in the investment agreements. ${ }^{104}$

Given that the Salini V. Jordan tribunal asserted jurisdiction only on claims based on the violations of the treaty but declined jurisdiction over contractual claims, it goes without saying that the burden of proof rested on the claimant to proof such matters of treaty practice by the host state. ${ }^{105}$ In Maffezini case, it was the expansively worded nature of the MFN clause that convinced the tribunal that the parties actually intended the provision to have a broad application. ${ }^{106}$ The absence of such a provision in Salini V. Jordan, coupled with the wordings of article 9 (2) of the Italy-Jordan BIT as has been noted by one observer, tells a great deal about the scope of Jordan's consent to arbitration with Italian investors. ${ }^{107}$ In other words, article 9 (2) established that Jordan did not consent to any arbitration of disputes with Italian investors. ${ }^{108}$

The Salini tribunal is justified not only because it correctly highlighted consent as a cornerstone of international law but moreover because of its observance that the MFN clause in BITs should not be interpreted in a manner that opens the gate for "treaty-shopping". ${ }^{109}$ Commenting on the Maffezini decision, the Salini tribunal observed thus: "The current tribunal shares the

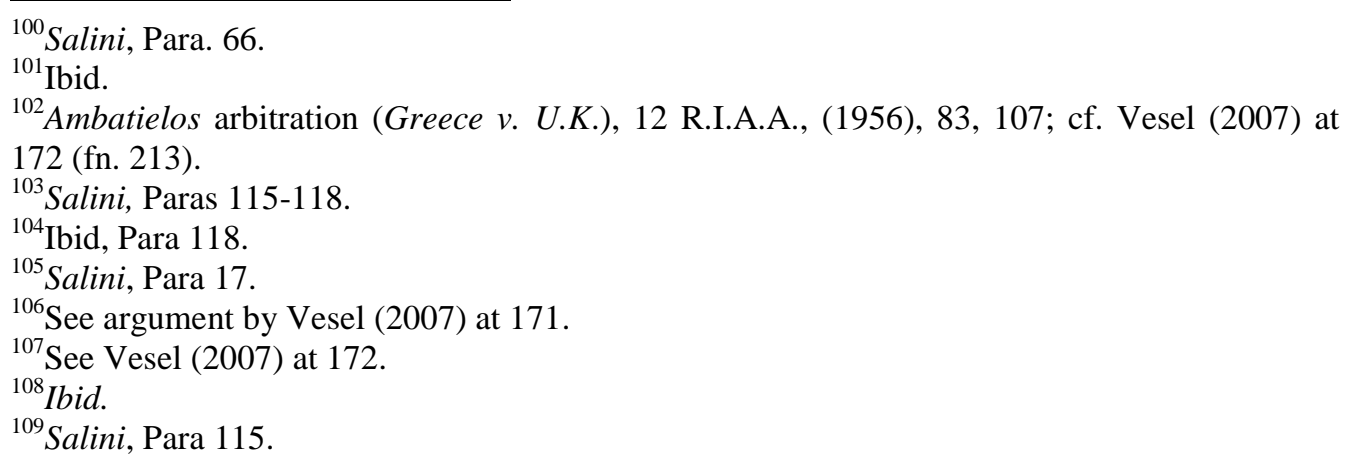


concerns that have been expressed in numerous quarters with regard to the solution adopted in the Maffezini case. Its fear is that the precautions taken by the authors of the award may in practice proof difficult to apply, thereby adding more uncertainties to the risk of treaty-shopping" 110 The Salini tribunal was in effect questioning the basis of the Maffezini caveat which stipulated that interpretations of MFN clauses should not overwhelm public policy concerns. It (the Salini tribunal) was particularly unconvinced such a public policy caveat would be enough to prevent investors from treaty-shopping by exploiting varying MFN provisions. ${ }^{111}$

\section{Plama Consortium Ltd v. Republic of Bulgaria ${ }^{112}$}

The Plama tribunal barely followed the rationale of the Salini decision by arguing in favour of a narrow interpretation of the MFN provision. It was also very sweeping in its critique of the Maffezini caveat.

The case involved a Cypriot investor whose corporation had purchased Nova Plama, a Bulgarian company that owned an oil refinery in Bulgaria. The claimant alleged facing difficult coercive measures from the Bulgarian authorities, which led to material damage on the operations of the refinery. ${ }^{113}$ Basing its claim on Part V of the Energy Charter Treaty (ECT) ${ }^{114}$ and the 1987 Bulgaria-Cyprus BIT, the claimant sought to resolve the dispute before an ICSID jurisdiction rather than through the Bulgarian courts, in order to benefit from the favourable MFN treatment in the Bulgaria-Finland BIT. ${ }^{115}$ The tribunal accepted the claimant's claims based on the ECT but rejected jurisdiction over those claims that were based on the BIT.

The Plama tribunal pointed out that Article 4 of the Bulgaria-Cyprus BIT allowed for a limited form of ad hoc UNCITRAL arbitration (a) only after a domestic court had determined that expropriation had occurred and (b) only to resolve disputes "with regard to the amount of compensation" due to an investor. ${ }^{116}$ It could be implied thus that "the MFN provision of the Bulgaria-Cyprus BIT cannot be interpreted as providing consent to submit a dispute under the BulgariaCyprus BIT to ICSID arbitration...and that the claimant cannot rely on dispute settlement provisions in other BITs to which Bulgaria is a contracting party in the present case." 117

The tribunal went on to assert that the MFN provision would apply to dispute settlement mechanism only when it is so evident in the language of the BIT as well

\footnotetext{
${ }^{110}$ Ibid.

${ }^{111}$ See Chalamish (2009) at 332

${ }^{112}$ See Plama Consortium Limited V. Republic of Bulgaria, ICSID Case No. ARB/03/24, Decision of February 8, 2005.

${ }^{113}$ Ibid, Para 21.

${ }^{114}$ See European Energy Charter Treaty of December 17, 1994, 33 I.L.M., (1995), p. 360.

${ }^{115}$ Bulgaria broadly consented to ICSID jurisdiction in the Bulgaria-Finland BIT. (See Plama, Paras 79, 99).

${ }^{116}$ Plama, Para 26.

${ }^{117}$ Ibid, Para 227.
} 
as the specific intent of the parties. ${ }^{118}$ To this effect, it considered the object and purpose of the Bulgaria-Cyprus BIT accordingly:

The object and purpose of the Bulgaria-Cyprus BIT are: 'The creation of favourable conditions for investments by investors of one Contracting Party in the territory of the other Contracting Party. '[...] The Claimant also points to the Maffezini decision in which it is observed: 'dispute settlement arrangements are inextricably related to the protection of foreign investors as they are also related to the protection of rights of traders under treaties of commerce.' Such statements are as such indeniable in their generality, but they are legally insufficient to conclude that the contracting parties to the Bulgaria-Cyprus BIT intended to cover by the MFN provision agreements to arbitrate in other treaties to which Bulgaria (and Cyprus for the matter) is a contracting party. Here, the tribunal is mindful of Sir Ian Sinclair's warning of the 'risk that the placing of undue emphasis on the object and purpose of the treaty will encourage teleological methods of interpretation [which], in some of its more extreme forms, will even deny the relevance of the intention of the parties. "II

Circumstantial evidence was determinant in the tribunal's conclusion. The Cyprus-Bulgaria BIT was signed when Bulgaria was still under communist rule, and did not generally provide for international arbitration as a means of resolving disputes. ${ }^{120}$ It was thus deduced that in the circumstances of the case, the intention of the parties was clearly not to extend dispute settlement mechanism through the MFN provision. ${ }^{121}$ The tribunal equally rejected the claimant's invocation of the MFN clause in the Bulgaria-Finland BIT on the ground that "It is one thing to add to the treatment provided in one treaty more favourable treatment provided elsewhere. It is quite another thing to replace a procedure specifically negotiated by parties with an entirely different mechanism." 122

Meanwhile the Maffezini] and the Siemens tribunals that interpreted silence to imply consent to the dispute settlement mechanism in the MFN clause; the Plama tribunal on the other hand differed and asserted that "one cannot reason $a$ contrario [where an MFN clause is silent] that the dispute settlement provisions must be deemed to be incorporated." "223 In other words, the MFN provision in a basic treaty does not prima facie incorporate in whole or in part to the dispute settlement mechanism in another treaty, unless the MFN clause in the basic treaty "leaves no doubt that the Contracting Parties intended to incorporate them." 124 A broad interpretation of the MFN provision could open the gates for investors to "treaty-shop" between jurisdictions for the best deals. Such a trend is very precarious because it would inevitable subject host states several dispute settlements to which they have not necessarily consented. ${ }^{125}$

\footnotetext{
${ }^{118}$ Ibid, Paras 204, 218, 221 and 223.

${ }^{119}$ Ibid, Para 193.

${ }^{120}$ Ibid, Paras 195-197.

${ }^{121}$ Ibid, Para 198.

${ }^{122}$ Ibid, Para 209.

${ }^{123}$ Ibid, Para 206.

${ }^{124}$ Ibid, Para 223.

${ }^{125}$ Ibid, Para 219.
} 


\section{Dispute Settlement Provision}

On a face value, BITs are designed to achieve two desirable objectives notably, the attraction of inward investments into a host state, and the protection of these investments and other investors' rights in the host state. In the preceding sections, I have examined the common substantive provisions (NT; FET and MFN) of Modern BITs. Beside these, there are also procedural norms to promote and protect FDI flows in[to] the host state.

Modern BITs generally provide for two separate dispute settlement provisions for State-to-state and Investor-to-state arbitrations. Considering the discrepancies of state-to-state arbitration (Diplomatic Protection), foreign investors often opt for direct Investor-State Arbitration (Investment Disputes). While in the former, it is the home state that pleads on behalf of its investors overseas, the latter on the other hand allows foreign investors to directly sue host states for the violation of investors' treaty rights. ${ }^{126}$ Obviously, this is a digression from the erstwhile traditional State-to-State adjudication mechanism. Two important developments in International Investment Law have facilitated this new arbitration, to wit: The establishment of International Centre for the Settlement of Investment Disputes (ICSID) as an arbitral institution in 1965 by the World Bank ${ }^{127}$, and the proliferation of BITs especially since the 1990s, most of which traditionally contain a reference to compulsory Investor-to-State arbitration under ICSID. The chief goal of the institution is to provide a conducive environment for private investment. ${ }^{128}$ According to the Report of the institution's Executive Directors, the primary aim of the ICSID Convention was to create "an institution designed to facilitate the settlement of disputes between states and foreign investors can be a major step forward promoting an atmosphere of mutual confidence and thus stimulating a larger flow of private international capital into those countries which wish to attract it." 129

The Dispute Settlement Provision is seen as the most important aspect of BITs, given that it provides the mechanism through which substantive rules of BITs can be enforced. ${ }^{130}$ Without the dispute settle clause, BITs would "represent merely an abstract declaration of the importance of FDI and its protection."131 Thanks to the provision, international law has undergone a completely new shift in favour of a strong recognition on non-state actors, advancing the rights of private parties to directly pursue claims under an international treaty, without appealing to their home state for assistance in pursuing such claims. ${ }^{132}$

\footnotetext{
${ }^{126}$ Infect, Diplomatic Protection adjudication can be characterized as Inter-Governmental Disputes. It generally provides for purely ad hoc arbitration, governed by the specific treaty rules. See Petrochilos, (2004) at 246-257. See also Dolzer \& Stevens (1995) at 119.

${ }^{127}$ See Convention on the Settlement of Investment Disputes between States and Nationals of Other States (ICSID), (1965), 575 United Nation Treaty Series (U.N.T.S) 159, 4 Int'l Legal Materials 524 (1965).

${ }^{128}$ See Dolzer \& Stevens (1995) at 20

${ }^{129}$ ICSID Convention, Report of the Executive Directors, Regulations \& Rules, at 40.

${ }^{130}$ See Freeman (2009) at 9.

${ }^{131}$ See Chalamish (2009) at 316.

${ }^{132}$ See Dolzer \& Stevens (1995) at 119; See also Freeman (2009) at 9 and Chalamish (2009) at 341.
} 


\section{Conclusion}

It is sometimes hard to see how and why developing countries are in such a mad rush for BITs-because the treaties' clauses pay little regard to the economic sovereignty of the host nations. Instead, they are focussed on magnanimous investors' rights and nearly ignoring investors' obligations, thereby effectively "preserving the dominance of investment interests in developing countries."133 The popularity of the treaties lie in the fact that host states agree to grant foreign investors with guarantees for National treatment vis-à-vis their own home investors; Fair and Equitable Treatment; Most Favoured Nation Treatment vis-àvis investors of other countries that are not party to the treaty, Free Transfer and Repartition of Profits, Compensation in the event of an Expropriation and Dispute Settlement Mechanism which allows foreign investors to bring claims against the host in an International Investment Arbitration Tribunal, in response to any violations of BITs obligations. ${ }^{134}$

Most of these guarantees turn to imply that foreign investors can potentially challenge virtually any public policy regulation by the host state that they construe to affect to affect them. ${ }^{135}$ Infect, BITs provisions generally touch on a common set of investment issues. Recent jurisprudence exemplifies the tendency of foreign investors relying almost always on a broad reading of BITs clauses in order to base their claims. Although some of these tribunals have actually concurred to such interpretations (Pope \& Talbot v. Canada, Marvin Roy Feldman, Maffezini and the Siemens), caution has also been exercised to prevent the temptation of "treatyshopping" (Mondev, S.D. Myers, Salini and Plama). Tribunals have demonstrated a willingness to treat every case on its merits. All the cases have typified that fact that the validity of a claim is chiefly determined by the language of the BITs clause. Where the scope of the provision expressly provides for limitation, tribunals must give it such an effect (Salini and Plama). The intention of the parties is paramount.

\section{References}

Adlung, R. \& M. Molinuevo (2008). 'Bilateralism and Services Trade: Is There Fire Behind the (BIT-) Smoke', in Journal of International Economic Law 11: 365-409.

Brower, H.Ch. (2001). 'Investor - State Disputes under NAFTA: The Empire Strikes Back' in Col. J. Transn. L. 40:43-88.

Brown, Ch.W. (2009). 'Investment Arbitration as the New Frontier', 28 The Arbitrator and Mediator 28(1):59-69.

Brownlie, I. (2008). Principles of Public International Law, $7^{\text {th }}$ ed. Oxford: Oxford University Press.

Busse, M., Königer, J. \& P. Nunnenkamp, (2010). 'FDI Promotion through Bilateral Investment Treaties: More Than a Bit?' in Review of World Economics 146:147-177.

\footnotetext{
${ }^{133}$ See Chalamish (2009) at 310.

${ }^{134}$ See Carlos (2004) at 312 and Chalamish (2009) at 310.

${ }^{135}$ See Neumayer \& Spess (2005) at 1571.
} 
Campbell, McLachlan, C., Shore, L. \& M. Weiniger (2007). International Investment Arbitration: Substantive Principles. (Oxford International Arbitration Series).Oxford: Oxford University Press. $2^{\text {nd }}$ ed. 2017.

Carlos, G. (2004). 'All the Other Dirty Little Secrets: Investment Treaties, Latin America, and the Necessary Evil of Investor-State Arbitration' in Florida Journal of International Law 16: 301-370.

Chalamish, E. (2009). 'The Future of bilateral Investment Treaties: A De Facto Multilateral Agreement?' in Brook. J. Int'l L. 34:303-354.

Chung, O. (2007). 'The Lopsided International Investment Law Regime and Its Effect on the Future of investor-State Arbitration ' in Va. J. Int'l L. 47: 953-958.

Convention on the Settlement of Investment Disputes between States and Nationals of Other States (ICSID), (1965), 575 United Nation Treaty Series (U.N.T.S) 159, 4 Int'l Legal Materials 524 (1965).

Dolzer, R. (2005). 'National Treatment: New Developments', Presentation for the ICSID, OECD AND UNCTAD co-organized Symposium, (Paris, Dec. 12, 2005).

Dolzer, R. \& M. Stevens (1995). Bilateral Investment Treaties. The Hague/Boston/ London: Martnus Nijhoff.

Fietta, S. (2005). 'Most Favoured Nation Treatment and dispute resolution under Bilateral Investment Treaties: A turning point' in International Arbitration Law review (2005) 131-138.

Franck, D.S. (2005). 'The Legitimacy Crisis in Investment Arbitration: Privatizing Public International Law Through Inconsistent Decisions' in Fordham Law Review 73: 1521-1625.

Freeman, N.W. (2009). The Determinants of Investor-State Disputes: Institutional Capacity and Compliance with Bilateral Investment Treaties', Paper presented at the annual meeting of the Southern Political Science Association, Hotel Intercontinental, New Orleans, LA, $7^{\text {th }}$ Jan. 2009 [Unpublished]

Freyer, D.H. \& D. Herlihy, (2005) 'Most-Favoured-Nation Treatment and Dispute Settlement in Investment Arbitration: Just How "Favoured" is "Most-Favoured"? ICSID Rev. in Foreign Inv. L. J., 20(1)58-83

Gaillard, E. (2005). 'Establishing Jurisdiction Through a Most-Favoured-Nation Clause' in New York Law Journal 233, No. 105, 1-9.

Gann, B.P. (1985). 'The US Bilateral Investment Treaty Program', in Stanford J. of Int'l L. 21: 373-376.

Garcia, C.G. (2004). 'All the Other Dirty Little Secrets: Investment Treaties, Latin America, and the Necessary Evil of Investor-State Arbitration', in Florida Journal of International Law 16: 301-370

Goodman, C.L. (2007). 'Unchartered Waters: Financial Crisis and Enforcement of ICSID Awards in Argentina' in University of Pennsylvania Journal of International Economic Law 28:449-486.

Greig, T.R., Annacker, C. \& R. Zaide (2008). 'How Bilateral Investment Treaties can protect Foreign Investors in the Arab World or Arab investors abroad' in Journal of International Arbitration 25:257-273.

Guzman Z., Elkins, A.T. \& B. Simmons (2006). 'Competing for Capital: The Diffusion of Bilateral Investment Treaties 1960 and 2000' in International Organization, 60:811846.

Guzman, A. (1998). 'Why LDCs Sign Treaties That Hurt Them: Explaining the Popularity of Bilateral Investment Treaties' in Virginia Journal of International Law 38:639688. 
Hamilton, C. \& P. Rochwerger (2005). 'Trade and Investment: Foreign Direct Investment through Bilateral and Multilateral Treaties' in New York International Law Review 18:1-59.

Havana Charter for an International Trade Organization (1948).

Houde, M-F (2004). 'Most Favoured Nation Treatment in International Investment Law', OECD Working Paper on International Investment, Number 2004/2, OECD Publishing. http://dx.doi.org/10.1787/518757021651

Kill, T. (2007). 'Don't Cross the Streams: Past and Present Overstatement of Customary International Law in Connection with Conventional Fair and Equitable Treatment Obligations', in Michigan Law Review 106:853-880.

Kurtz, J. (2002). 'A General Investment Agreement in the WTO? Lessons from Chapter 11 of NAFTA and the OECD Multilateral Agreement on Investment' in University of Pennsylvania Journal of International Economic Law 23:713-790.

Malnik, M. (2009). 'Fair and equitable treatment', International Institute for Sustainable Development (IISD), (Working Paper series, Bulletin \#3, September 2009). "Fairness" and "Equity" and fundamental principles recognized by virtually every legal system.

Mann, A.F. (1981). 'British Treaties for the Promotion and Protection of Investments', in B.Y.I.L 52: 241-254.

Mann, H. \& K. von Moltke (2004). 'Protecting Investor Rights and the Public Good: Assessing NAFTA's Chapter 11' Background Paper to the ILSD Tri-National Policy Workshops, Mexico City: March 13; Ottawa March 18; Washington: April 11, 2003.

Nash, M. (1993). 'Contemporary Practice Of The United States Relating To International Law-Bilateral Investment Treaties' in American Journal of International Law 87: 433-441.

Neumayer, E. \& L. Spess (2005). 'Do bilateral investment treaties increase foreign direct investment to developing countries? 'in World Development Journal 33:1567-1585.

Newcombe, A. \& L. Paradell (2008). Law and Practice of Investment Treaties: Standards of Treatment/ The Hague: Kluwer Law International.

Paterson, R.K. (1991). 'Canadian Investment Promotion and Protection Treaties' 29 on Canadian YB of Int'l L. 29: 373-390.

Petrochilos, G. (2004). Procedural Law in International Arbitration, (Oxford: Oxford University Press.

Radi, Y (2007). 'The application of the most favoured nation clause to the dispute settlement provisions of bilateral investment treaties: Domesticating the Trojan Horse' 18 EJIL, doi: 10.1093/ejil/chm031

Ranjan, P. (2007). 'Bilateralism, MFN and TRIPS: Exploring Possibilities of Alternative Interpretation' in International Trade Law and Regulation 13: 67-78.

Robin, P.M. (1984). "The BIT Won't Bite: The American Bilateral Investment Treaty Program", in American University Law Review, 33:931-958.

Salacuse, J.W. \& N.P. Sullivan (2005), 'Do BITs Really Work? An Evaluation of Bilateral Investment Treaties and Their Grand Bargain', in Harvard International Law Journal 46: 67-130.

Salacuse, J.W. (1990). 'BIT by BIT: The Growth of Bilateral Investment Treaties and their Impact on Foreign Investment in Developing Countries', in The International Lawyer, 24: 655-675.

Schill, S.W. (2009). 'Multilateralizing Investment Treaties Through Most-Favoured-Nation Clauses', in Berk. J. of Int'l L. 27(2):496-569.

Schreuer, C. (2005). 'Fair and Equitable Treatment in Arbitral Practice', in Journal of World Investment and Trade, 6:357-386. 
Tobin, J. \& S. Rose-Ackerman (2005). 'Foreign direct investment and the business environment in developing countries: The impact of bilateral investment treaties 'in Yale Law School Center for Law, Economics and Public Policy Research Paper No. 293. doi:10.2139/ssrn.557121.

Trebilcock, J.M. \& K.S. GIRI (2004). Handbook of International Trade, Vol. I, E. Kwan Choi \& James C. Hartigan (Eds). Oxford: Blackwell.

Trebilcock, J.M. \& R. Howse (2005). The Regulation of International Trade. $3^{\text {rd }}$ ed. New York: Routledge.

Tudor, I. (2009). 'The Fair and Equitable Treatment Standard in the International Law of Foreign Investment. 2008, Oxford: Oxford University Press' in EJIL 20:229-239.

UNCTAD 1999, Fair and Equitable Treatment (UNCTAD Series on Issues in International Investment Agreements, 1999) UNCTAD/ITE/IIT/11 (Vol. III) ((United nations, New York and Geneva)

UNCTAD 2005, Investor-State Disputes Arising from Investment Treaties: A Review, (UNCTAD series on International Investment Policies for Development, 2005)

UNCTAD 2008, Recent Developments in International Investment Agreements (2007June 2008) 2 IIA Monitor (2008), U.N. Doc. UNCTAD/WEB/DIAE/IA/2008/1.

UNCTAD 2009, 'Latest Developments in Investor- State Dispute Settlement', IIA Monitor No. 1 (2009), (United nations, New York and Geneva)

Vandevelde, J.K. (1996). Book Review and Note, 'Bilateral Investment Treaties, by Rudolf Dolzer \& Margrete Stevens' in American Journal of International Law 90(3): 545547. doi:10.2307/2204091

Vandevelde, J.K. (1998). 'Investment Liberalization and Economic Development: The role of Bilateral Investment Treaties', in Colum. J. Trans. L. 36: 501-528.

Vesel, S. (2007). 'Clearing a path through a tangle jurisprudence: Most-Favoured -Nation clause and dispute settlement provisions in Bilateral Investment Treaties', in Yale Journal of International Law, 32(1):125-189.

Wong, J. (2008). 'The Application of the Most-Favoured-Nation Clauses to Dispute Resolution Provisions in Bilateral Investment Treaties', in 3 Asian J. W.T.O. \& Int'l Health L. \& Pol'y, 3:171-192.

Yackee, J.B. (2009). 'Pacta Sunt Servanda and State Promises to Foreign Investors before Bilateral Investment Treaties: Myth and Reality' in Fordham International law Journal 32:1550-1613.

Yannaca-Small, C. (2004). 'OECD, Fair and Equitable Treatment Standard in International Investment Law' (Working papers on International Investment, Number 2004/3, Paris, OECD, 2004).

Ziegler, A.R. (2008). 'Most-Favoured-Nation (MFN) Treatment', in: A. Reinisch (ed.), Standards of Investment Protection. Oxford: Oxford University Press, at pp. 29-86.

Ziegler, A.R. (2010). 'The Nascent International Law on Most-Favoured-Nation (MFN) Clauses in Bilateral Investment Treaties (BITs)', in Eur. YB of Int'l Econ. L., 1:77101.

\section{Cases}

Emilio Agustion Maffezini v. Kingdom of Spain, ICSID Case No. ARB/97/7, Decision of January 25, 2000.

LFH Neer \& Pauline Neer (USA) v. United Mexican States (1926) IV RIAA 60.

Marvin Roy Feldman Karpa v. United Mexican States, ICSID Case No. ARB(AF)/99/1, (16 December 2002). 
Mondev International Ltd v. United States, Award, ICSID Case No ARB(AF)/99/2; IIC 173, (2002).

Plama Consortium Limited v. Republic of Bulgaria, ICSID Case No. ARB/03/24, Decision of February 8, 2005.

Pope \& Talbot v. Canada, Award, April 10th 2001, 7 ICSID Reports.

Ronald S. Lauder v. The Czech Republic, Final Award, ${ }^{\text {rd }}$ Sep. 2001, 9 ICSID Reports.

S.D. Myers Inc. v. Canada, First Partial Award of November 13, 2000 (Hunter, Chiasson, Schwartz), 40 ILM 1408 (2001).

Salini Construttori S.p.A and Italstrade S.p.A v. The Hashemite Kingdom of Jordan, ICSID Case No. ARB/02/13, Decision of November 15, 2004.

Siemens A.G. v. The Argentina Republic, ICSID Case No. ARB/02/8, Decision of August 3, 2004.

The Ambatielos case, U.N. Reports of Int'l Arbitral Awards, 1963

The Treaty between the Federal Republic of Germany and Pakistan for the Promotion and Protection of Investments (Germany v. Pakistan (1959)), 457 U.N.T.S. 23. 